\title{
Time-Slice Maps Showing Age, Distribution, and Style of Deformation in Alaska North of $60^{\circ} \mathrm{N}$.
}

By Thomas E. Moore and Stephen E. Box

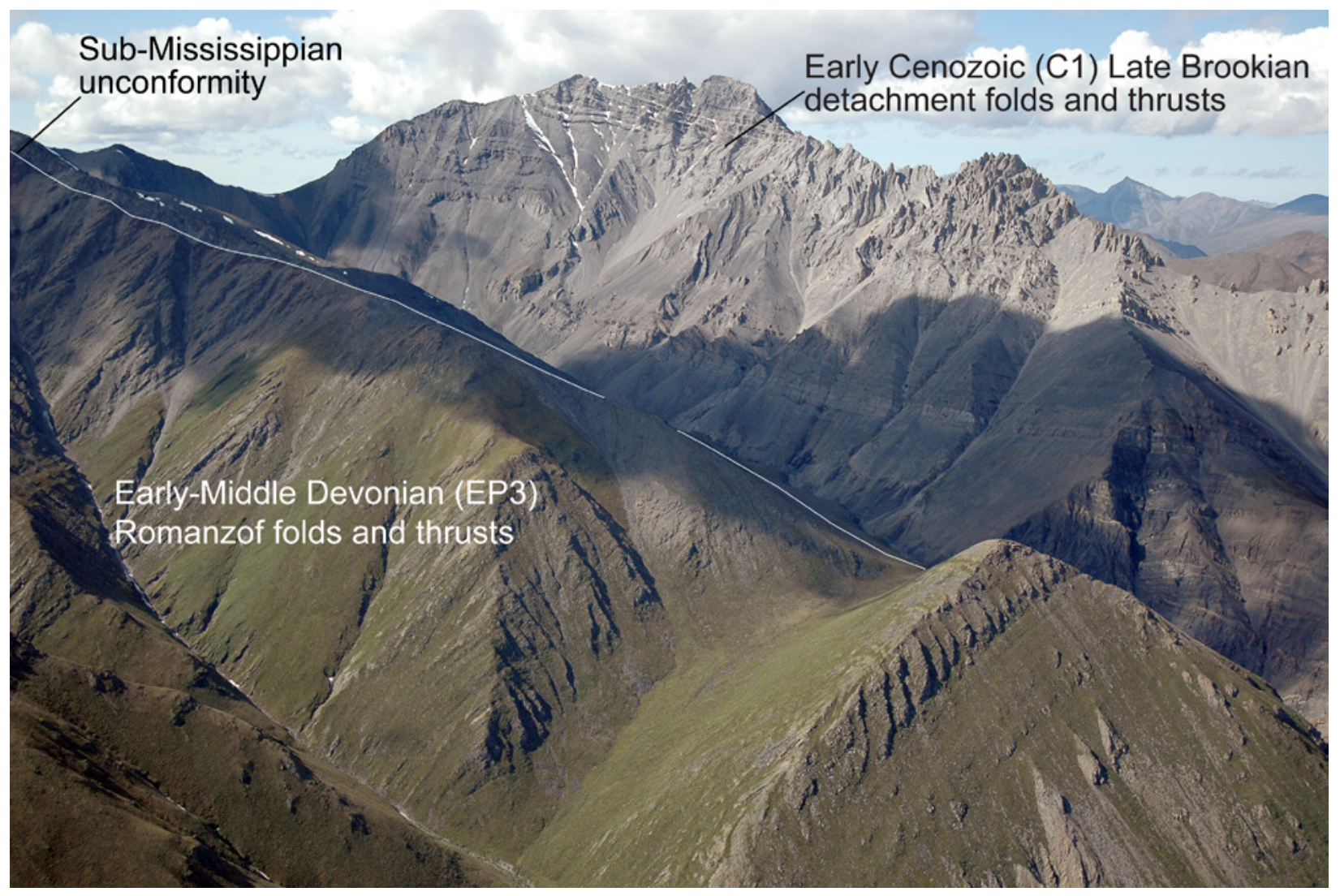

Open-File Report 2016-1138

U.S. Department of the Interior U.S. Geological Survey 
Cover. Northwesterly view west of the Canning River in the Franklin Mountains of the northeastern Brooks Range showing superposed deformational events. In the foreground Neoproterozoic Neroukpuk Quartzite is deformed by Early to Middle Devonian contractional deformation of the Romanzof Orogeny (EP3 deformation) and truncated by a regional sub-Mississippian unconformity at white line. In the middleground, the Lower Mississippian Kayak Shale and Mississippian and Pennsylvanian Lisburne Group above the unconformity are deformed by Early Cenozoic thrusttruncated detachment folds emanating from a flat thrust in the Kayak Shale during Late Brookian (C1) deformation. The entire structural section visible in the photograph is tilted northward owing to Early Cenozoic basement-involved thrusting that occurred later during the same Late Brookian (C1) deformational event. Photograph by Thomas E. Moore. 


\section{U.S. Department of the Interior SALLY JEWELL, Secretary}

\section{U.S. Geological Survey \\ Suzette M. Kimball, Director}

U.S. Geological Survey, Reston, Virginia: 2016

For more information on the USGS - the Federal source for science about the Earth, its natural and living resources, natural hazards, and the environment-visit http://www.usgs.gov/ or call 1-888-ASK-USGS (1-888-275-8747).

For an overview of USGS information products, including maps, imagery, and publications, visit http://store.usgs.gov.

Any use of trade, firm, or product names is for descriptive purposes only and does not imply endorsement by the U.S. Government.

Although this information product, for the most part, is in the public domain, it also may contain copyrighted materials as noted in the text. Permission to reproduce copyrighted items must be secured from the copyright owner.

Suggested citation:

Moore, T.E., and Box, S.E., 2016, Time-slice maps showing age, distribution, and style of deformation in Alaska north of $60^{\circ}$ N.: U.S. Geological Survey Open-File Report 2016-1138, 101 p., http://dx.doi.org/10.3133/ofr20161138.

ISSN: 2328-0328 (online) 


\section{Contents}

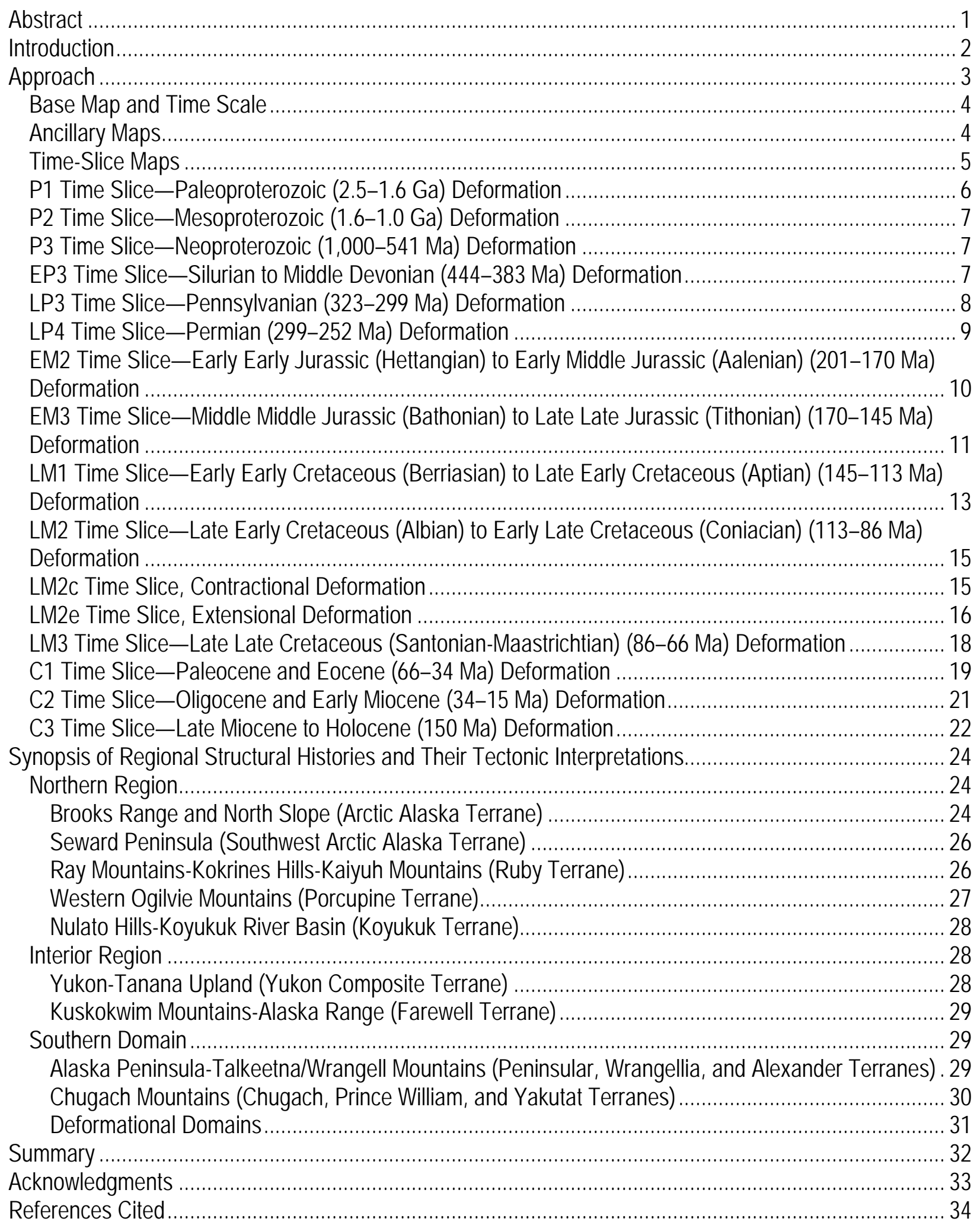




\section{Figures}

1. Time scale from Cohen and others (2013) divided into 20 labeled time intervals defined by the working group for the Tectonic Map of the Arctic and adjusted to fit the geology of Alaska.....

2. Physiographic map of Alaska north of latitude $60^{\circ} \mathrm{N}$. and adjacent area, showing important cities and towns, major rivers, and geographic features referred to in this paper.....

3. Geologic map of Alaska with unit descriptions, adapted from Harrison and others (2011) with additional structures added for this report

4. Tectonostratigraphic terrane map of Alaska, generalized from Silberling and others (1992) by combining similar and related terranes.

5. Map of Alaska showing major Cretaceous and Cenozoic clastic basins...................................... 68

6. Map of Alaska showing distribution of ophiolitic sections of mafic and ultramafic intrusive rocks, of accretionary assemblages composed primarily of basalt and interleaved chert, of accretionary assemblages composed primarily of clastic sedimentary rocks, and of sedimentary molasses facies (shallow marine to nonmarine) deposited in a foreland basin setting

7. Map showing distribution of greenschist-, blueschist-, amphibolite-, and eclogite-facies rocks in Alaska north of $60^{\circ} \mathrm{N}$

8. Maps showing distribution of areas in Alaska affected by P1 deformation $(2.5-1.6 \mathrm{Ga}$, Paleoproterozoic)

9. Maps showing distribution of areas in Alaska affected by P2 deformation (1.6-1.0 Ga, Mesoproterozoic)

10. Maps showing distribution of areas in Alaska affected by P3 deformation (1,000-541 Ma, Neoproterozoic).

11. Maps showing distribution of areas in Alaska affected by EP3 deformation (444-383 Ma, SilurianMiddle Devonian, Rhuddanian-Givetian).....

12. Maps showing distribution of areas in Alaska affected by LP3 deformation (323-299 Ma,

Pennsylvanian)

13. Maps showing distribution of areas in Alaska affected by LP4 deformation (299-252 Ma, Permian)

14. Maps showing distribution of areas in Alaska affected by EM2 deformation (201-170 Ma, Early Jurassic, Hettangian-Aalenian).

15. Maps showing distribution of areas in Alaska affected by EM3 deformation (170-145 Ma, Middle and Late Jurassic, Bajocian-Tithonian).

16. Maps showing distribution of areas in Alaska affected by LM1 deformation (145-113 Ma, early Early Cretaceous, Berriasian-Aptian).

17. Maps showing distribution of areas in Alaska affected by LM2c (compressive) deformation (113-86 Ma, late Early-early Late Cretaceous, Albian-Coniacian) …….............................................. 89

18. Maps showing distribution of areas in Alaska affected by LM2e (compressive) deformation (113-86 $\mathrm{Ma}$, late Early -early Late Cretaceous, Albian-Coniacian) ....................................................... 91

19. Maps showing distribution of areas in Alaska affected by LM3 deformation (86-66 Ma, late Late Cretaceous, Santonian-Maastrichtian)......

20. Maps showing distribution of areas in Alaska affected by $\mathrm{C} 1$ deformation (66-34 Ma, PaleoceneEocene).

21. Maps showing distribution of areas in Alaska affected by C2 deformation (34-15 Ma, Oligoceneearly Miocene)

22. Maps showing distribution of areas in Alaska affected by C3 deformation (15-0 Ma, middle Miocene-Recent)..... 
23. Map showing deformational domains of Alaska with terranes and major Cenozoic strike-slip faults shown for reference.

\section{Tables}

1. Table summarizing by age interval (see fig. 1) and location (see fig. 2 for locations of quadrants) the style, age constraints, kinematics, tectonic context, and sources of information for deformational episodes distinguished in this study

2. Kinematic information for structural transport directional indicators shown in figures $11-22$........ link 


\title{
Time-Slice Maps Showing Age, Distribution, and Style of Deformation in Alaska North of $60^{\circ} \mathrm{N}$.
}

\author{
By Thomas E. Moore and Stephen E. Box
}

\begin{abstract}
The structural architecture of Alaska is the product of a complex history of tectonism that occurred along the Cordilleran and Arctic margins of North America through interactions with ancient and modern ocean plates and with continental elements derived from Laurentia, Siberia, and Baltica. To unravel the tectonic history of Alaska, we constructed maps showing the age, distribution, structural style, and kinematics of contractional and penetrative extensional deformation in Alaska north of latitude $60^{\circ} \mathrm{N}$. at a scale of $1: 5,000,000$. These maps use the Geologic Map of the Arctic (Harrison and others, 2011) as a base map and follow the guidelines in the Tectonic Map of the Arctic project (Petrov and others, 2013) for construction, including use of the International Commission on Stratigraphy time scale (Cohen and others, 2013) divided into 20 time intervals. We find evidence for deformation in 14 of the 20 time intervals and present maps showing the known or probable extent of deformation for each time interval. Maps and descriptions of deformational style, age constraints, kinematics, and information sources for each deformational episode are discussed in the text and are reported in tabular form. This report also contains maps showing the lithologies and structural geology of Alaska, a terrane map, and the distribution of tectonically important units including post-tectonic sedimentary basins, accretionary complexes, ophiolites, metamorphic rocks.

These new maps show that most deformational belts in Alaska are relatively young features, having developed during the late Mesozoic and Cenozoic. The oldest episode of deformation recognized anywhere in Alaska is found in the basement of the Farewell terrane ( 1.75 Ga). Paleozoic and early Mesozoic deformational events, including Devonian deformation in the Arctic Alaska terrane, Pennsylvanian deformation in the Alexander terrane, Permian deformation in the Yukon Composite (Klondike orogeny) and Farewell terranes (Browns Fork orogeny), Early and Late Jurassic deformation in the Peninsular-Wrangellia terranes, and Early Cretaceous deformation in northern Alaska (early Brookian orogeny) show that within-terrane amalgamation events occurred prior to assembly of Alaska. Widespread episodes of deformation in the Late Cretaceous and early Cenozoic, in contrast, affected multiple terranes, indicating they occurred during or following the time of assembly of most of Alaska.

The primary deformational event in northern Alaska was the Late Jurassic and Early Cretaceous (early) Brookian orogeny, which affected most terranes north and west of the early Cenozoic Tintina, Victoria Creek, Kaltag, and Poorman dextral-slip faults in central Alaska. In southern Alaska, formation of the southern Alaska accretionary complex (Chugach, Prince William, Yakutat terranes) and associated magmatism in the Peninsular-Wrangellia terrane began near the Triassic-Jurassic boundary and continued episodically throughout the remainder of the Mesozoic and the Cenozoic. The collision of these terranes with the Farewell and Yukon
\end{abstract}


Composite terranes in central Alaska is recorded by contractional deformation that emanated from the intervening basins in the Late Cretaceous. The boundary between northern and central Alaska is constrained to late Early Cretaceous but is enigmatic and not obviously marked by contractional deformation. Early Cenozoic shortening and transpressional deformation is the most widespread event recorded in Alaska and produced the widespread late Brookian orogenic event in northern Alaska. Middle and late Cenozoic shortening and transpression is significant in southern Alaska inboard of the underthrusting Yakutat terrane at the Pacific margin subduction zone as well as in northeastern Alaska.

\section{Introduction}

Tectonism has long been recognized to be widespread, diverse, and complex in Alaska. Deformed rocks are found from the Beaufort Sea in the north to the Pacific Ocean in the south and include folds and thrust faults, ductile and brittle normal faults, and strike-slip faults that range in age from Proterozoic to Neogene. The structures were formed in a variety of tectonic settings, including subduction accretion, arc and continental collision, ridge subduction, retroarc thrusting, rifting, transform fault systems, and other settings. Metamorphic rocks are key units in Alaska that underlie large parts of the State and record multiphase ductile deformation at a variety of pressure and temperatures conditions (Dusel-Bacon, 1994a,b). Alaska, with the Russian Far East, forms part of a region of accreted rock units that intervenes between the Siberian craton to the west and the Laurentian craton to the east. Alaska also straddles an enigmatic geologic boundary between the Cordilleran orogenic belt of western North America, which extends northwestward along the Pacific margin into southern Alaska, and the deformational belts of the Arctic realm that extend from the east and west into northern Alaska. Consequently, the timing, nature, and style of deformation of Alaska have outstanding importance to the history of assembly of the Arctic and North Pacific regions.

Although a number of tectonic models have been developed for Alaska (for example, Plafker and Berg, 1994; Nokleberg and others, 2000; Johnston, 2001; Colpron and others, 2006), there has not been a rigorous descriptive assessment of the age, character, distribution, and kinematics of deformational structures at a regional scale. Instead, studies of the deformational history of Alaska over the past 30 years have largely focused on the nature and distribution of stratigraphic assemblages and mapping of tectonostratigraphic terranes (for example, Coney and Jones, 1985; Silberling and others, 1992; Plafker and Berg, 1994; Nokleberg and others, 2000) and more recently on the late Cenozoic tectonics of southern Alaska (for example, EberhartPhillips and others, 2006; Haeussler, 2008; Finzel and others, 2011). Deformational structures and fabrics provide direct evidence of tectonic events by which orogenically complex regions are assembled and represent important sources of information for deciphering the interaction and amalgamation of terranes into continental regions through time.

The impetus for this publication stems from a request for structural and tectonic information about Alaska for the construction of a tectonic map of the Arctic, part of an atlas of maps currently being compiled by the geological surveys of Circum-Arctic countries under the auspices of the United Nations Educational, Scientific, and Cultural Organization (UNESCO) Commission for the Geological Map of the World (CGMW). The tectonic map is currently being assembled by a working group composed of an international group of scientists under Russian leadership (Petrov and others, 2013). The tectonic map is being constructed at a scale of 1:5,000,000 and covers the Arctic region north of latitude $60^{\circ} \mathrm{N}$. A modern assessment of the 
structural and tectonic history of Alaska is essential for a compilation of the Alaskan component of the Circum-Arctic tectonic map and is a fundamental descriptive contribution in its own right.

The objective of this report is to contribute maps showing the distribution of deformational structures across Alaska north of latitude $60^{\circ} \mathrm{N}$. in a series of time slices at a scale of 1:5,000,000. A geographic information system (GIS) database of this project is currently in preparation. In effect, we attempt to distinguish and map significant deformational features as separate events (for example, D1, D2, D3) in every part of Alaska north of latitude $60^{\circ} \mathrm{N}$. and to document their distribution and their deformational style, kinematics, and timing constraints. Ancillary maps that show the present structural geologic framework, the distributions of tectonically important metamorphic and structural-stratigraphic rock assemblages, and Cretaceous and Cenozoic depositional basins are also included for reference. We believe that these new maps contribute a database of structural features that offer a unique perspective and will contribute to the understanding of the kinematic processes that formed the structural and tectonic architecture of Alaska. This report provides much of the underlying information about the structural history of Alaska and its implications for the tectonic assembly of the Alaskan crust that are discussed in Moore and Box (2016).

\section{Approach}

The maps in this report focus on contractional deformation because contractional deformation has been a dominant tectonic process in the formation of Alaska. In our study, we define deformed areas on the basis of evidence of penetrative and nonpenetrative shortening, including penetrative fabric elements, folds, and faults without regard to their style of deformation, depth to detachment, or magnitude of the shortening. Because of its fundamental importance in Alaska, however, we have also mapped areas displaying extensional penetrative deformation, most of which falls into the time period LM2, which corresponds to 113-86 Ma. Areas of nonpenetrative extensional deformation are not included in the maps. Also not mapped, are areas of Alaska where thermochronology indicates that high rates of cooling have occurred, but coeval geologic structures on which exhumation occurred have not been recognized in the field. Although such cooling may be explained as plateau-style uplift, this type of deformation is disregarded where associated faults and folds are absent.

Areas of brittle extensional deformation are commonly difficult to define because subsequent deposition of subsidence-related sedimentary cover or because of tectonic inversion by younger episodes of deformation. Consequently, areas of brittle extensional deformation are commonly not well portrayed on maps of Alaskan geology. For this reason, we have not attempted to map these types of structures.

Likewise, the narrow aerial expression of strike-slip faults preclude analysis in the context of our time-slice maps, except where they are accompanied by broadly distributed transpressional and transtensional deformation. Although critically important components of the deformational history of Alaska, strike-slip faults and their displacement histories are incompletely understood, despite constraints provided by a number of studies (for example, St. Amand, 1957; Grantz, 1966; Brogan and others, 1975; Lahr and Plafker, 1980; Nokleberg and others, 1985, 1994; Page and others, 1991, 1995; Plafker and Berg, 1994; Dover, 1994; Lowey, 1998; Haeussler and others, 2000; Gabrielse and others, 2006; Pavlis and Roeske, 2007;

Haeussler, 2008). Here, we have limited discussion of strike-slip fault locations to showing them on the time-slice maps and including information about their timing and amount of displacement (where known) where it is relevant to our study. 
We delineated areas affected by each deformation episode on the basis of geologic evidence. The evidence used to construct the maps comes from geologic maps and reports, discussions with scientists who have studied the areas in question, and from our own experience investigating rocks of northern and central Alaska (Thomas Moore), and central, western, and southern Alaska (Stephen Box). Constraints on the timing of deformation in specific areas are developed from stratigraphic observations such as angular unconformities, crosscutting igneous features, structural correlations, outcrop and microfabric studies, and direct geochronologic and thermochronologic dating of observed geologic structures. The limits of distribution of areas affected by each deformation are based on the continuity of the affected rocks in outcrop and the compatibility of the style and geometry of the deformation. In some cases, judgment was used to extend the areas involved in deformation beyond the areas of demonstrated age control or other critical geologic information. Descriptions of the characteristics of specific episodes of deformation, evidence for their ages, their distributions and kinematics, and pertinent references used in this study are listed by region in table 1 .

\section{Base Map and Time Scale}

The base map for the project is the GIS version of the Geologic Map of the Arctic (Harrison and others, 2011). For the most part, we have assigned deformational episodes to the units they affected on a polygon-by-polygon basis as depicted in this map (that is, by stratigraphic unit as well as location) as geologic evidence dictates. Where deformation extends over broad areas, all stratigraphic units (that is, the polygons on the base map) of the same or older age than the deformation are interpreted as deformed (for example, plutonic rocks cutting strata that are later folded). In a few places, where the polygons that form the digital mapping are inadequate to portray the known structural relations, we have subdivided the polygons. Because the geologic base map was compiled by simplification of existing geologic maps, it will be possible for future workers to revisit our compilation and update or modify the database by reassigning the deformation using more detailed geologic maps and information.

The time scale employed in this project is that of Cohen and others (2013), a time scale that was sponsored by the CGMW and adopted by the working group for the Tectonic Map of the Arctic. For the purpose of classifying tectonic episodes in the Arctic, the working group divided the time scale into 20 time intervals (fig. 1). Of the 20 time intervals, our mapping of deformation in Alaska indicates that deformation occurred during 14 of them. The time intervals for which there are deformational episodes in Alaska are colored in figure 1.

\section{Ancillary Maps}

The area of our study is defined on the east by the international border between the United States and Canada at longitude $141^{\circ} \mathrm{W}$., on the west by the international border between the United States and Russia along longitude 168 $58^{\prime} 37^{\prime \prime}$ W. north of the Bering Strait, and trends southwestward from the Bering Strait across the Bering Sea to the south (fig. 2). The southern boundary of the study area is at latitude $60^{\circ} \mathrm{N}$. to agree with the southern boundary of the Tectonic Map of the Arctic. The northern boundary lies along the continental margin of Alaska in the Arctic Ocean. Figure 2 shows the physiography of Alaska on a digital topographic base and includes a reference grid that is used for discussion in the text and in table 1.

The geologic base map used for mapping the distribution of deformational episodes in Alaska from Harrison and others (2011) is shown in figure 3. The color scheme of the map is simplified by showing related units in the same color. Labels shown on the map and in the map 
explanation can be used to distinguish constituent subunits that share the same color. Structural features (faults and folds) have been modified and expanded from those shown by Harrison and others (2011) on the basis of literature and recent studies.

A tectonostratigraphic terrane map of Alaska is shown in figure 4 for reference. This map was simplified from the classic tectonostratigraphic terrane map of Silberling and others (1992) by combining smaller terranes now known to have stratigraphic affinity or continuity with larger adjacent terranes and by not showing post-amalgamation sedimentary cover. Post-amalgamation cover strata are subdivided into separate basins in figure 5 and are assigned to deformed and undeformed basin types by age. Figure 5 illustrates that most Cretaceous basins, and some Cenozoic basins of Alaska have been structurally deformed.

For simplicity of presentation, the nomenclature for several terranes has been modified in this paper. First, the Angayucham, Tozitna, and Innoko terranes in interior Alaska are discussed as a single terrane, the Angayucham-Tozitna-Innoko (ATI in fig. 4) terrane, because all consist of similar allochthonous assemblages of late Paleozoic and early Mesozoic oceanic rocks (for example, Moore and others, 1994; Plafker and Berg, 1994). Second, although the Alexander, Wrangellia, and Peninsular terranes are retained as separate terranes on figure 4 and in the text, we refer to all three terranes collectively as the Alexander-Wrangellia-Peninsular composite terrane when discussing their post-amalgamation tectonic history (for example, Nokleberg and others, 1994; Plafker and others, 1994). Third, to avoid confusion across the United StatesCanada border, we followed Dusel-Bacon and Williams (2009) in dividing the Yukon-Tanana terrane into structurally lower and higher parts (fig. 4). The structurally lower, parautochthonous part (YTp in fig. 4) consists of rocks that were reclassified as part of ancestral North America by Colpron and others (2006), whereas the structurally higher, allochthonous part (YTa in fig. 4) encompasses rocks considered to be allochthonous due to the collisional Klondike orogeny of the Yukon Territory (for example, Beranek and Mortensen, 2011). Colpron and others (2006) restricted the term "Yukon-Tanana terrane" to only those rocks in the structurally higher part of the Yukon-Tanana terrane and this usage recently has been widely adopted by Canadian geologists, although Alaskan geologists still generally use the definition of Silberling and others (1992). In this paper, we use the term "Yukon Composite terrane" of Plafker and Berg (1994) to indicate the terrane as defined by Silberling and others (1992).

Figure 6 shows the distribution of tectonically important lithologic assemblages, including ophiolites, accretionary assemblages composed primarily of basalt and chert, accretionary assemblages composed principally of clastic sedimentary rocks, and nonmarine and shallow marine topset facies sedimentary sequences in foreland basins that are sometimes classified as sedimentary molasse facies. Areas of exposure of recrystallized metamorphosed rocks, divided into greenschist and amphibolite facies, are shown in figure 7. Locations where blueschist mineral assemblages (generally heavily retrograded to greenschist facies in Alaska) and eclogite assemblages have been identified are shown as point localities.

\section{Time-Slice Maps}

In figures 8-22 we present time-slice maps showing the nature and extent of contractional and penetrative extensional deformation in Alaska, progressing from oldest to youngest. Each time-slice map is presented in two formats: in the " $A$ " figure, each geologic unit polygon affected by the deformation is highlighted and unaffected polygons are shown in outline; in the " $B$ " figure, areas of similar deformational style are generalized by interpolating through areas covered by thin younger units and (or) separated by younger magmatic bodies. The 
“ $B$ ” figures also show arrows indicating contractional (yellow) or penetrative extensional (blue) deformation where evidence is available. Single-headed arrows show the direction of structural transport, whereas double-headed arrows show the orientation of contraction or extension. Kinematic indicators used to determine the direction of tectonic transport are primarily based on the orientation and asymmetry of folds on published geologic maps, but also include published shear sense indicators from outcrop studies and microfabric studies. Table 1 provides documentation of the structural style, the timing of deformation, the direction of tectonic transport (if known), and references that give documentation. The information is referenced to a Statewide grid shown in figure 2 and in figures 8-22. Table 2 shows the type of kinematic feature and data represented by each kinematic arrow in the time-slice maps and provides a reference from which the information was taken.

The structural styles we used to characterize the deformation on the maps are as follows: (1) thin-skinned thrust style, where deformation consists dominantly of thrust faults contained in a concordant, originally flat-lying sedimentary cover succession; (2) thin-skinned fold style, where deformation consists dominantly of folds developed in a concordant, originally flat-lying sedimentary cover succession; (3) basement-involved thrust style, where deformation consists mainly of thrust faults that involve basement as well as sedimentary cover rocks, with basement being defined as consisting of crystalline rocks or previously deformed sedimentary or metasedimentary successions; (4) basement-involved fold style, where deformation consists mainly of folds that involve basement as well as sedimentary cover rocks, with basement being defined as consisting of crystalline rocks or previously deformed sedimentary or metasedimentary successions; (5) accretionary sedimentary style, where deformation typically consists mainly of imbricate or inhomogeneous thrusting developed in water-saturated clastic lithologies, and olistostromes; (6) accretionary igneous style, where deformation consists of imbricate or inhomogeneous thrusting of mainly igneous rocks and pelagic sedimentary rocks; (7) transpressional thrust style, where thrusting is oblique and (or) can be resolved into mappable contractional and strike-slip components; (8) transpressional fold style, where folding is oblique and (or) can be resolved into mappable contractional and strike-slip components; (9) penetrative contractional style in metamorphic rocks with pervasive planar and (or) linear contractional fabric elements; (10) penetrative extensional style in metamorphic rocks with pervasive planar and (or) linear extensional fabric elements; (11) other structural style, where deformation is different from the above; and (12) uncertain deformational style, where the style has not been determined.

In the following section, we provide summaries for the deformational belts present in each of the time slices, highlight key aspects of the deformation, and note the geologic and tectonic settings in which the deformation occurred.

\section{P1 Time Slice-Paleoproterozoic (2.5-1.6 Ga) Deformation}

The earliest dated deformation (P1) within Alaska is recorded in penetratively deformed amphibolite-facies metasedimentary rocks with metamorphic ages near $1.75 \mathrm{Ga}$ in the Kanektok and Idono complexes in southwest Alaska, considered parts of the Kilbuck terrane (Turner and others, 2009) (fig. 8, table 1). Little is known of the structural geology of these rock fabrics. Older igneous rocks within these complexes have isotopic evidence for incorporation of underlying Archean crustal rocks. Some authors have argued that these complexes were originally contiguous but were later separated by Cretaceous dextral strike-slip faulting (Box and others, 1990; Miller and others, 1991). Bradley and others (2014) presented evidence that these 
metamorphic complexes are part of the crustal basement of the much more widespread Farewell terrane (fig. 4).

\section{P2 Time Slice-Mesoproterozoic (1.6-1.0 Ga) Deformation}

P2 deformation (1.6-1.0 Ga) is known from penetratively deformed amphibolite-facies metasedimentary rocks in the Kanektok and Idono complexes (Kilbuck terrane) in southwest Alaska, and from penetratively deformed amphibolite-facies metasedimentary rocks in basement rocks underlying the Paleozoic section of the Farewell terrane in the northern Kuskokwim Mountains (fig. 9, table 1). Turner and others (2009) and Bradley and others (2014) reported metamorphic amphibole Ar-Ar ages between 1.2 and $1.0 \mathrm{Ga}$ in each of these complexes. Little is known of the structural geology of their rock fabrics. Bradley and others (2014) presented evidence that these metamorphic complexes are all part of the crustal basement of the much more widespread Farewell terrane (fig. 4).

\section{P3 Time Slice-Neoproterozoic (1,000-541 Ma) Deformation}

P3 deformation (1,000-541 Ma) is recorded in penetratively deformed greenschist-facies metamorphic rocks unconformably underlying Ordovician carbonate rocks of the Farewell terrane in the northern Kuskokwim Mountains (fig. 10, table 1). Bradley and others (2003a, 2014) reported metamorphic white mica and biotite ${ }^{40} \mathrm{Ar} /{ }^{39} \mathrm{Ar}$ ages of $921-663 \mathrm{Ma}$ from these rocks. Little is known of the structural geology of their rock fabrics.

Neoproterozoic deformation has also been noted from the core of the Nanielik antiform in the southwestern Brooks Range, where penetratively deformed amphibolite and continental metasedimentary rocks yield white mica ${ }^{40} \mathrm{Ar} /{ }^{39} \mathrm{Ar}$ ages of 730 to $680 \mathrm{Ma}$ (Till and others, 2008). However, these rocks are reported to be intruded by post-tectonic granitic rocks with U-Pb zircon ages of $750 \pm 6 \mathrm{Ma}$ (Karl, Aleinikoff, and others, 1989), implying an older age for the deformation. The deformation in this area is the oldest known in northern Alaska, but its significance is uncertain because of questions about its extent and paleogeographic position prior to younger Mesozoic tectonic events.

\section{EP3 Time Slice-Silurian to Middle Devonian (444-383 Ma) Deformation}

The oldest Phanerozoic deformation recognized in Alaska is the middle Paleozoic (EP3) Romanzof orogeny (Lane, 2007) which is found in northern Alaska. Devonian deformation may also be present in the Livengood terrane in central and east-central Alaska (fig. 11, table 1). In the Brooks Range, the deformation is recognized beneath the regional sub-Mississippian unconformity in autochthonous and parautochthonous structural settings of the Mesozoic and Cenozoic Brookian orogenic belt. It is also been interpreted from seismic data beneath Cretaceous Colville Basin and the continental shelf to the north.

Deformational fabrics are best developed in the northeastern Brooks Range where northdirected semipenetrative to penetrative fabrics with low greenschist-facies mineral assemblages are found in Early Devonian (Emsian) and older rocks. This deformation produced tight to isoclinal folds, north-directed thrust faults, and slaty cleavage in argillaceous rocks and a spaced fracture cleavage in sandstones (Lane and others, 1995). The Paleozoic structures are clearly truncated by the Okpilak batholith, which has yielded a latest Devonian ( 360 Ma) U-Pb age (T. Moore, unpub. data; Lane, 2007), and by the younger sub-Mississippian unconformity (Reiser and others, 1980). These relations place firm younger age limits on the deformation. The age of 
the deformation may be more tightly constrained by Eifelian (early Middle Devonian) rift-basin sediments (Popov and others, 1994) that are interpreted as resting unconformably on deformed strata as young as Emsian (late Early Devonian) in age (Anderson, 1991; Anderson and others, 1992). This relation, however, is only inferred from the contrasting stratigraphies of adjacent Paleogene (late Brookian) thrust imbricates. Steeply dipping clastic strata lying beneath the Mississippian unconformity in the Topagoruk well in the central North Slope are interpreted to be Middle Devonian on the basis of plant fossils (Dumoulin, 2001) and Early Devonian on palynology (R.L. Ravn, written commun. to R. Blodgett, 2008). Because of the uncertainty of the age of this deformation, we simply refer to the Romanzof orogen as "Devonian” in this paper.

Strata beneath the sub-Mississippian unconformity in the Mount Doonerak window in the central Brooks Range are tilted but display weak or no penetrative fabrics (Julian and Oldow, 1998). Tilted early Paleozoic greywacke turbidites beneath the regional sub-Mississippian unconformity in the Lisburne Peninsula (western Brooks Range) display asymmetric folds and moderately south-dipping, spaced to slaty cleavage that indicate generally north-vergent kinematics. These rocks are juxtaposed against tilted Ordovician graptolitic shales at a relatively younger Silurian or Devonian south-dipping extensional fault (Moore and others, 2002). The geologic relations of this area are poorly studied, however, and it remains possible that the folding and extensional faulting may alternately be interpreted as Early Cretaceous (early Brookian) and Paleogene, respectively.

The Devonian deformational fabrics may comprise a north-vergent thrust system that resulted from the collision of the northern part of Baltica against the northern margin of North America prior to rotational rifting of Arctic Alaska away from North America in the Mesozoic (Strauss and others, 2013; Moore, 2013). The Devonian deformation in northern Alaska might constitute an older phase of the Ellesmerian orogeny of northern Canada (Lane and others, 1995), or it might represent an extension of the Caledonian orogenic belt into Alaska (Moore and Bird, 2009).

In the Livengood terrane, a mafic and ultramafic complex composing the lower part of an ophiolite of Neoproterozoic or Cambrian age is thrust onto a continental geologic section composed of Neoproterozoic to Silurian carbonate rocks and chert (Amy Creek Dolomite, Livengood Dome Chert, Lost Hills unit of Weber and others [1992]). Both sections are unconformably overlain by a coarse-grained clastic succession (Middle Devonian Cascadin Ridge and similar Devonian units of Weber and others [1992]) that may represent a post-tectonic overlap succession. Alternatively, the angular relations could be explained as a highly extended early Paleozoic continental margin that was depositionally overlapped by the Devonian clastic units and later inverted by thrusting during middle-Cretaceous time. The Livengood terrane is a fault sliver that was translated along the early Cenozoic Tintina Fault from an original location in the northwestern Canadian Cordillera, possibly near the Dawson thrust where Cambrian ultramafic rocks of uncertain composition have been mapped in association with similar stratigraphy and structural relations (for example, Colpron, 2012).

\section{LP3 Time Slice-Pennsylvanian (323-299 Ma) Deformation}

Pennsylvanian (LP3) deformation in Alaska is restricted to a small area in the southeastern part of the map area (fig. 12) within the Alexander terrane. Little is known of this deformation in Alaska beyond the map description of the unit (MacKevett, 1978). The deformed unit has yielded fossils as young as Mississippian and crosscutting granitic plutons have yielded Late Pennsylvanian ages (309 \pm 5 Ma, Gardner and others, 1988; $307 \pm 4$ Ma, Beranek and 
others, 2014). The deformed rocks are foliated metasedimentary greenschist and locally amphibolite-facies metamorphic rocks with evidence of folded schistosity. This deformation may correlate with deformation dated at 315-307 Ma by Beranek and others (2014) in the Alexander terrane in the Yukon. They interpreted this deformation as recording the collisional amalgamation of the Alexander and Wrangellia terranes.

\section{LP4 Time Slice-Permian (299-252 Ma) Deformation}

Permian LP4 deformation affected the entire Farewell terrane across central Alaska, the Tikchik terrane in southwestern Alaska, and the upper structural plate of the Yukon Composite terrane (YTa) in east-central Alaska (fig. 13; table 1).

Bradley and others (2003a, 2014) termed the Permian deformation of the Farewell terrane the Browns Fork orogeny. They documented the orogen in the northern part of the terrane from metamorphic fabrics that overprint both Proterozoic greenschist-facies rocks and Paleozoic marbles that overlie them and obtained ${ }^{40} \mathrm{Ar} /{ }^{39} \mathrm{Ar}$ metamorphic mica ages of 285-284 Ma from the deformed rocks. These rocks occur beneath an unconformity, which is overlain by Permian conglomeratic strata containing clasts of Farewell Paleozoic detritus with deformational fabrics. In the southern part of the terrane, a Permian conglomeratic basin-fill sequence containing deformed Farewell Paleozoic detritus may represent the foreland basin to the orogenic belt (Bradley and others, 2003a).

The Tikchik terrane (Hoare and Coonrad, 1978) consists of a Paleozoic clastic mélange and an associated Pennsylvanian-Mississippian oceanic arc complex to the west (Box and others, 2015) that are unconformably overlain by middle Permian conglomeratic strata. The clastic mélange has northeast structural vergence and dominantly Precambrian detrital zircon signatures similar to those in Farewell terrane strata. Box and others (2015) interpreted the arc and mélange as a genetically related arc-trench system.

The Permian Browns Fork orogen in the Farewell terrane, dated at $285 \mathrm{Ma}$ (LP4, fig. 13), is interpreted as a terrane-wide collisional orogenic event, with the Farewell terrane forming the lower plate of the orogen (Bradley and others, 2003a). Recent work suggests this event may have been driven by partial underthrusting of the Farewell terrane beneath an oceanic arc terrane, identified either as the Alexander-Wrangellia terrane to the east (Beranek and others, 2014; Malkowski and Hampton, 2014) or the Tikchik terrane to the west (Box and others, 2015).

The late Permian Klondike orogeny (Beranek and Mortensen, 2011) is recognized in the Yukon Territory of Canada near the international border and probably extends into eastern Alaska, where pre-latest Triassic (>212 Ma) deformation has been recognized in the allochthonous, structurally higher part (YTa) of the Yukon Composite terrane (Hansen, 1990; Pavlis and others, 1993; Hansen and Dusel-Bacon, 1998; Dusel-Bacon and others, 2002) (fig. 13). In Alaska, the YTa is composed of a metamorphic assemblage that consists of amphibolitefacies metasedimentary and metavolcanic rocks, marble, and granodioritic to tonalitic orthogneiss of Early Mississippian age (Dusel-Bacon and others, 2013, 2015). The mafic and ultramafic Seventymile terrane, correlative with the Slide Mountain terrane in the Yukon (Hansen, 1990; Hansen and Dusel-Bacon, 1998), is also allochthonous and consequently has been assigned to the YTa. Both the Seventymile and Slide Mountain terranes have been interpreted as oceanic crust (representing the Seventymile-Slide Mountain Ocean) but include basinal sediments that were emplaced into a continentward-facing accretionary prism, outboard of the margin of North America in the late Paleozoic (Tempelman-Kluit, 1979; Hansen, 1990; Dusel-Bacon and others, 1995, 2006). 
In Alaska, the deformation produced penetrative metamorphic fabrics in the structurally higher assemblage with kinematic features indicating northeastward structural vergence prior to intrusion of Triassic granitic plutons (Hansen and Dusel-Bacon, 1998; Dusel-Bacon and others, 2015) (fig. 13). The Seventymile terrane, however, is generally not penetratively deformed except along its basal contact (Pavlis and others, 1993; Hansen and Dusel-Bacon, 1998). Kinematic indicators along this contact also verge to the northeast and are attributed to deformation associated with the emplacement of these rocks (Hansen, 1990; Pavlis and others, 1993; Hansen and Dusel-Bacon, 1998). Permian deformational fabrics, however, have not been recognized in the structural lower part (YTp) of the Yukon Composite terrane (Dusel-Bacon and Williams, 2009), although such fabrics might not be recognized because of intense episodes of overprinting deformation in the Jurassic and Cretaceous.

Poorly dated eclogitic metabasites in the Chatanika klippe near Fairbanks (fig. 13, YTc) display kinematic indicators indicating northeast vergence, which may suggest that eclogites were formed during the Permian deformational event. If this is correct, the klippe may represent either (1) an imbricated assemblage of metabasalts developed within the YTp and thus provide evidence for subduction of these rocks or (2) isolated remnants of an allochthonous subduction assemblage associated with the YTa (for example, the Seventymile terrane) and thus formed during the pre-latest Triassic deformational event (Pavlis and others, 1993; Dusel-Bacon and others, 2006) (fig. 13).

The top-to-the-northeast kinematics of this mid-crustal deformation probably resulted from west-dipping subduction of oceanic crust of the Seventymile-Slide Mountain Ocean Basin beneath an offshore Permian (260-252 Ma) magmatic arc that was built on a microcontinental block. Most workers agree that the microcontinental block is a Neoproterozoic and (or) early Paleozoic marginal facies of North America that had previously rifted away from the Laurentian craton in the Devonian during formation of the Seventymile-Slide Mountain Ocean (Nelson and others, 2006; Mair and others, 2006; Beranek and Mortensen, 2011; Dusel-Bacon and others, 2013). The Permian subduction led to construction of an accretionary prism composed of imbricated assemblages from the basin and emplacement of the outboard arc and continental basement complex of the structurally higher assemblage onto the northwestern margin of North America (that is, the structurally lower assemblage of the Yukon Composite terrane) in the Permian (Tempelman-Kluit, 1979; Hansen and Dusel-Bacon, 1998; Nelson and others, 2006). Upper Triassic North American-derived clastic sediments overlap the collisional zone, which suggests the collision was completed by the Late Triassic (Beranek and Mortensen, 2011).

\section{EM2 Time Slice-Early Early Jurassic (Hettangian) to Early Middle Jurassic (Aalenian) (201- $170 \mathrm{Ma}$ ) Deformation}

Early Jurassic EM2 deformation affected the entire Yukon Composite terrane of eastcentral Alaska, the Peninsular terrane in the Talkeetna Mountains, the Chugach terrane in the Chugach Mountains of southeast and south-central Alaska, and the Koyukuk terrane in westcentral Alaska (fig. 14; table 1).

The entire Yukon Composite terrane (YTa, Ytp, YTc; fig. 14) was subjected to intense and pervasive ductile penetrative deformation in the Early Jurassic under greenschist- to amphibolite-facies conditions at intermediate to high pressure corresponding to crustal depths estimated to be greater than $15 \mathrm{~km}$ (Dusel-Bacon and others 1995, 2002; Day and others, 2002; Dusel-Bacon and Williams, 2009). The Early Jurassic deformation was accompanied by widespread synkinematic Early Jurassic granitic magmatism (Hansen and Dusel-Bacon, 1998). 
The deformation displays top-to-the-northwest, orogen-parallel kinematics, suggesting it was caused by shortening that was oblique to the continental margin (Hansen and Dusel-Bacon, 1998) (fig. 14).

Until recently, the tectonic cause of the Early Jurassic deformation was thought to be caused by the closing of the Slide Mountain-Seventymile Ocean Basin by westward subduction of the North American margin beneath an outboard continental arc and backarc basin in the Jurassic (for example, Hansen and Dusel-Bacon, 1998). Beranek and Mortensen (2011) reported that North American-derived clastic sediments overlap the collision zone and therefore suggested the basin-closing event occurred in the Permian (see LP4 time slice). As a result of this reinterpretation, the Early Jurassic deformation is now thought to reflect a later episode of backarc thrusting behind a west-facing Triassic to Early Jurassic arc-trench system that followed the Permian deformational event (Dusel-Bacon and others, 2015). The backarc thrusting was probably oblique because orogen-parallel kinematic indicators are reported from these rocks (Hansen and Dusel-Bacon, 1998) (fig. 14).

In the Chugach Mountains just south of the Border Ranges Fault, sparse slivers of Early Jurassic (locally latest Triassic) blueschist-facies metamorphic rocks provide the earliest evidence of subduction beneath the Peninsular $(\operatorname{arc})$ terrane from the south and document the earliest phase of accretion in the Chugach accretionary prism (Forbes and Lanphere, 1973; Roeske and others, 1989; Plafker and others, 1989, 1994). The prominent sub-Middle Jurassic angular unconformity in the Peninsular arc terrane (Trop and others, 2005) and cooling of the deeper roots of the Peninsular arc (Hacker and others, 2011) document a period of Early and (or) Middle Jurassic deformation of uncertain style and kinematics. This deformation and uplift of Chugach blueschist-facies metamorphic rocks in the forearc (Roeske and others, 1989) were linked by Clift and others (2005) and Amato and others (2013) to Early Jurassic tectonic erosion in the forearc of the Peninsular terrane. They further suggested that the tectonic erosion may have ended the episode of high pressure/temperature $(\mathrm{P} / \mathrm{T})$ metamorphism in the nascent Chugach accretionary complex.

In the Koyukuk terrane in western Alaska, altered Late Triassic-Early Jurassic(?) non-arc basalts are cut by locally mylonitic internal shear zones and by fault-bounded packages of limestone and folded Triassic chert (Patton and others, 2006) that are crosscut by post-tectonic Middle and Late Jurassic granitic arc plutons (Box and Patton, 1989; Patton and Moll-Stalcup, 1996). Little is known about the character and significance of this deformational episode; whether this deformation predates the birth of the oceanic arc or follows earlier arc magmatism is uncertain.

\section{EM3 Time Slice-Middle Middle Jurassic (Bathonian) to Late Late Jurassic (Tithonian) (170- $145 \mathrm{Ma}$ ) Deformation}

Middle and Late Jurassic EM3 deformation is recorded within the Angayucham-TozitnaInnoko terranes of northern and central Alaska, and within the Wrangellia and Peninsular terranes in southern Alaska (fig. 15; table 1).

Widely dispersed but volumetrically minor mafic and ultramafic parts of a suprasubduction-zone ophiolite succession occur as structural klippe faulted over the allochthonous basalt-chert assemblages of the Angayucham-Tozitna-Innoko terrane. Amphibolitic tectonites (170-165 Ma) are present along the contact (Loney and Himmelberg, 1989; Harris, 1998, 2004; fig. 6). Metamorphic fabrics in the amphibolites indicate northwestward structural vergence for the emplacement of the Misheguk Mountain, Avan Hills, and Sinektanneyak ophiolites in 
klippen in the western Brooks Range (fig. 15; Harris, 2004). Within the basalt-chert assemblages, vergence direction has not been documented but is assumed to be similar. Patton and Box (1989) and Patton and others (2009) interpreted the tectonite as representing a paleosubduction zone between the deeper crustal portion of the Koyukuk arc terrane and accreted oceanic plate rocks in an accretionary prism now represented by the basalt-chert assemblage. Structural dips of the tectonites, basalt-chert assemblages, and ophiolites are generally southward on the northern flank of the Koyukuk terrane and northwestward along its southeast flank (Patton and Box, 1989). These dips, however, may have been produced by subsequent tectonic processes.

Contraction within the Peninsular arc is recorded by reverse motion along the more than 500-km long, arc-parallel, southeast-vergent Bruin Bay-Little Oshetna Fault. This fault bounds the northeastern margin of, and is syntectonic with, directly adjacent Upper Jurassic sedimentary deposits (including Naknek Formation), which are thought to have been deposited in a southeastfacing forearc basin (Trop and others, 2005). The large throw and length of the Bruin Bay-Little Oshetna Fault suggest it may represent part of a southeast-vergent basement-involved thrust belt that runs down the length of the Peninsular terrane. The aerial extent of the thrust belt is uncertain but is inferred to include other northeast-trending faults in the Peninsular terrane (fig. $15)$.

Deformation in the Wrangellia terrane is recorded by the penetratively deformed Strelna metamorphic assemblage and the northeast-vergent Chitina fold-and-thrust belt to the north. The Chitina fold-and-thrust belt is erosionally overlain by Lower Cretaceous (Hauterivian) strata on an angular unconformity, which provides a minimum age for the deformation (MacKevett, 1978; Plafker and others, 1989; Trop and others, 2002). Trop and others (2002) described Upper Jurassic syntectonic deposits in the thrust belt, which we accept as evidence that the thrusting was Late Jurassic. The Strelna metamorphic assemblage is located along the southern margin of the Wrangellia terrane and is intruded by synkinematic plutons that yield ages of 158-148 Ma. This assemblage, which we conclude constitutes the metamorphic hinterland for the Chitina thrust belt, displays inhomogeneous fabrics, including locally penetrative deformation and complex folds of bedding (Plafker and others, 1989; Nokleberg and others, 1994).

The Strelna complex appears to continue northwest under the Copper River Basin into the northern Talkeetna Mountains where it is called the metamorphic complex of Gulkana River (Nokleberg and others, 1994). These rocks are folded and contain locally mylonitic schistosity that is east trending and steeply dipping (Csejtey and others, 1978; Nokleberg and others, 1994). As with the Strelna complex, the Gulkana River complex is intruded by foliated, synkinematic plutons that yielded U-Pb crystallization ages of 158-148 Ma (Rioux and others, 2007). Although shown by Silberling and others (1992) as Peninsular terrane (figs. 4 and 8-22), the southwestern extent of this deformational belt has been reinterpreted by Glen and others (2007) to be part of the Wrangellia terrane. A north-vergent thrust belt similar to the Chitina fold-andthrust belt has not been recognized north of the Gulkana River metamorphic complex in the Talkeetna Mountains, possibly because of a deeper level of erosion there.

Although the origin and kinematics of the Strelna are complex and uncertain, this deformational belt may have resulted from collision between the Wrangellia and Peninsular terranes along a north-dipping subduction zone, or alternatively from compression of unspecified cause within an already amalgamated Peninsular-Wrangellia terrane (Clift and others, 2005; Rioux and others, 2007; Amato and others, 2013). 


\section{LM1 Time Slice-Early Early Cretaceous (Berriasian) to Late Early Cretaceous (Aptian) (145- $113 \mathrm{Ma}$ ) Deformation}

Early Cretaceous LM1 contractional deformation is a defining feature of northern Alaska. This deformational episode affected the east-west-trending, 1,000-km-long Brooks Range, the northwest-trending Wrangel-Herald Arch in the Lisburne Peninsula of northwestern Alaska, and a northeast-southwest-trending thrust belt in the western Ogilvie Mountains near the United States-Canada border in east-central Alaska (fig. 16, table 1). Rocks with metamorphic fabrics developed at this time are widespread in the Seward Peninsula, southern Brooks Range, and the Kuskokwim and Ray Mountains (Ruby terrane).

In the Brooks Range, early Brookian deformation produced a north-directed fold-andthrust belt that features a series of far-traveled allochthons in the northern Brooks Range and a penetratively deformed, blueschist-facies hinterland metamorphic belt in the southern Brooks Range and Seward Peninsula (fig. 16; Moore, Grantz, and Roeske, 1994). The presence of blueschist-facies assemblages in continental rocks in the hinterland, and the structurally highest allochthons composed of ophiolite of supra-subduction-zone type above an accretionary prism composed of basalt and chert (both included in the Angayucham-Tozitna-Innoko terrane), led to the interpretation that Brookian deformation was the result of subduction of a south-facing continental margin southward beneath an oceanic volcanic arc now represented by the Koyukuk terrane (Box, 1985; Moore, Grantz, and Roeske, 1994). Stratigraphic relations and Ar-Ar ages indicate the deformation began to involve continental crust of the Arctic Alaska terrane by the Berriasian stage; thrust-related deformation in the foreland probably ended by the Aptian (Mull, 1985); backfolding occurred in the metamorphic hinterland in the Albian (Vogl, 2002, 2003).

The location of the Seward Peninsula south of the westerly trend of the Brookian hinterland can be attributed to either (1) southward orogenic curvature of the hinterland belt, (2) younger southward translation of the Seward Peninsula by a north-trending sinistral fault, or (3) to exhumation of a downdip part of the Brookian subduction assemblage in the western part of the orogeny, although metamorphic facies constraints may not support the latter interpretation (S. Roeske, University of California, Davis, written commun., 2015). Kinematic indicators suggest northward tectonic transport in the Seward Peninsula (Patrick, 1988), although Hannula and others (1995), working in different areas of the Seward Peninsula, attributed similar kinematic features to extensional LM2e deformation. The east-vergent kinematics in the Lisburne Peninsula at the extreme west end of the Brooks Range contrasts with the northward vergence of the main part of the Brookian thrust belt (fig. 16). This abrupt orogenic curvature may result from an east-to-west change to thicker continental crust beneath the Chukchi Plateau in the Chuckchi Sea west of northern Alaska (Moore and others, 2002).

Although the Ruby terrane is structurally overlain by rocks of the Angayucham-TozitnaInnoko terrane in the Kuskokwim and Ray Mountains and contains blueschist mineral assemblages that yield Early Cretaceous Ar-Ar ages like those of the hinterland belt in the southern Brooks Range, the cause of its conspicuously divergent trend relative to the Brooks Range is controversial. LM1 deformation in the Ruby terrane has been determined to be northwest-directed in two areas (fig. 6; Dover, 1994; Roeske and others, 1995), the reverse of that expected if driven by northwestward underthrusting of the Ruby terrane beneath the Koyukuk arc. More work is needed to understand LM1 kinematics in this part of Alaska.

Early Cretaceous deformation in the western Olgivie Mountains near the Canadian border in east-central Alaska is suggested by southeast-directed thrust sheets composed of outer continental margin strata as young as Early Cretaceous (Porcupine terrane). These are capped by 
a poorly exposed thrust sheet consisting of rocks of the Angayucham-Tozitna-Innoko terrane (Johnsson, 2000; Till and others, 2006; Rohr and others, 2008). The presence of a northeasttrending late Early Cretaceous foreland basin (Kandik River sequence), developed on parautochthon composed of North American craton rocks to the east, supports this interpretation and suggests that the thrust sheets were thrust onto the North American margin without significant lateral displacement. Continentward thrusting similar in timing and style to early Brookian deformation in the Brooks Range suggests both deformational belts originally formed along the northwestern margin of North America, with the Brooks Range subsequently rotated counterclockwise away from that margin into its present position by opening of the Canada Basin (western Arctic Ocean) (Johnsson, 2000).

Early Cretaceous LM1 deformation is also recorded locally in southern Alaska, including the Goodnews and Kilbuck terranes in the Ahklun Mountains, and the Nutzotin Basin in the Alaska Range, and within the McHugh Complex in the Chugach Mountains on the east side of Cook Inlet. The Goodnews and Kilbuck terranes record low-grade metamorphic overprints with similar timing and metamorphic facies (greenschist-blueschist) to that of northern Alaska, interpreted to result from southeastward underthrusting of the continental Kilbuck terrane beneath the Goodnews terrane, which is interpreted to be the accretionary forearc to the adjacent Togiak intraoceanic arc terrane (Box and others, 1993).

In the northern Wrangell Mountains, Lower Cretaceous strata of the Nutzotin Basin are deformed by southwest-vergent Early Cretaceous folds and thrust faults. These structures are cut by post-tectonic plutons with K-Ar ages from 117 to 105 Ma (Richter and others, 1975; Manuszak and others, 2007), providing a minimum age for the thrusting. To the northeast, Nutzotin Basin strata are separated from older continental rocks (Yukon Composite terrane) by the Cenozoic Denali Fault, so whether this LM1 deformation represents the initial collision of the Alexander-Wrangellia-Peninsular terrane with North America or some other tectonic episode is uncertain. On the other hand, Manuszak (2007) concluded that deformation of the Nutzotin Basin continues to the southwest across the Totschunda Fault onto the northern Wrangellia terrane, indicating only small amounts of displacement have occurred on the fault. Although Manuszak (2007) portrayed the deformation southwest of the fault as similar to that to the north, maps of the area suggest a more complex deformational style. For this reason, we show the deformational style of this area as uncertain (fig. 16B).

North-directed subduction along and south of the Border Ranges Fault (Pavlis and Roeske, 2007) in the Early Cretaceous resulted in continued assembly of the accretionary prism that composes the Chugach terrane. On the basis of detrital zircon ages, Amato and others (2013) reported that a narrow inner part of subduction assemblage (Potter Creek assemblage of McHugh complex) was accreted to the forearc during the latest Jurassic and Early Cretaceous and was affected by tectonic erosion associated with subduction of a spreading ridge at 125 Ma. Together, the accretion and ridge subduction events resulted in inhomogeneous fabrics, disharmonic folding, broken formation and locally ductile deformation of the Potter Creek assemblage (Pavlis and others, 1988; Amato and Pavlis, 2010; Labrado and others, 2015). The timing of this deformation is constrained by the maximum depositional age from detrital zircons of younger than 169-156 Ma from the Potter Creek and the time of trondhjemite intrusion generated by ridge subduction at $125 \mathrm{Ma}$ (Amato and others, 2013). Day and others (2011) reported detrital zircon maximum depositional ages of 137 Ma from the Liberty Creek blueschist to the east (fig. 16), indicating the penetrative fabric in that unit is probably Early Cretaceous. 


\section{LM2 Time Slice-Late Early Cretaceous (Albian) to Early Late Cretaceous (Coniacian) (113- $86 \mathrm{Ma})$ Deformation}

Time interval LM2 covers the middle Cretaceous from the Albian to the Coniacian stages (113-86 Ma) and is represented by brittle contractional deformation in east-central Alaska and widespread penetrative extensional deformation in the Seward Peninsula and in the southern Brooks Range, as well as in the Ruby and Yukon Composite terranes. To distinguish between these distinctive episodes of deformation, we have mapped the distributions of contractional and penetrative extensional structures separately, designating the contractional structures as LM2c (fig. 17) and the extensional deformation as LM2e (fig. 18).

\section{LM2c Time Slice, Contractional Deformation}

Contractional structures assigned to LM2c are present in the Brooks Range and in southern and east-central Alaska (fig. 17, table 1). Following a period of subduction erosion in the Early Cretaceous, thrust slices of volcanic, chert, and clastic units (McHugh Creek assemblage of Amato and others, 2013) were accreted from 101 to $91 \mathrm{Ma}$ along the southern margin of Alaska. This accretion, offscraped during northwestward underthrusting of oceanic crust of the paleo-Pacific Ocean, built much of the early, innermost part of the long-lived Chugach subduction complex.

Although middle Cretaceous deformation in the metamorphic hinterland of the Brooks Range is dominantly extensional, south-vergent contractional deformation has been reported from a regional culmination in the Arrigetch Peaks area that exposes the deepest parts of the central Brooks Range (fig. 17). Mull (1978) noted apparent regional south-vergent folding and thrusting of metamorphic layering and Vogl (2002) described mesoscopic folds, penetrative schistosity, and a regional nappe that suggest crustal-scale backfolding and thrusting. Timing of backfolding is constrained between $\sim 112$ and 103 Ma (early to middle Albian) by ${ }^{40} \mathrm{Ar} /{ }^{39} \mathrm{Ar}$ dating of mica and hornblende from older early Brookian contractional fabrics and from younger extensional fabrics (Vogl, 2002; Vogl and others, 2002). Vogl (2002), however, noted that the south-vergent contractional fabrics are difficult to distinguish from extensional fabrics and that the mechanical influence of large Devonian granitic batholiths on deformation in this area is unknown (Vogl, 2002). Working in an adjacent area to the west, Toro and others (2002) did not report evidence of back folding. To the east, Avé Lallemant and Oldow (1998) attributed mesoscopic south-vergent folds to antithetic shear emanating from a subsurface ramp associated with development of the early Cenozoic (C1) Mount Doonerak antiform.

LM2c deformation is also found close to the international border in east-central Alaska, where the arcuate, east-west-trending, north-vergent Mackenzie Mountains foreland fold-andthrust belt of the Canadian Yukon Territories terminates at its western end against the northwesttrending Tintina Fault just inside Alaska. Lower Cretaceous strata are folded by east-westtrending folds (Dover and Miyaoka, 1988; Dover, 1992) and, to the east, strata at least as young as Albian are folded by east-west-trending structures on the southern margin of the Eagle Plain in the Yukon (Gordey and Makepeace, 2001). This indicates that the deformational belt is no older than Albian. Fission-track data indicating uplift-related cooling at 96-86 Ma support this conclusion (Johnsson, 2000). Linkage of the Alaskan structures to the Mackenzie Mountains fold-thrust belt to the east ties this deformation to the Rocky Mountains orogen and thus to the Cordilleran, rather than to the Arctic, margin of North America. 
To the west, south of the junction between the Tintina and Kaltag Faults, LM2c structures are documented in the Livengood area between these faults on the north and the Yukon Composite terrane to the southeast. Here, northeast-trending map-scale folds deform Albian and older strata and are intruded by granitic rocks dated at 92-88 Ma (Reifenstuhl and others, 1998). The deformation forms a northwest-vergent fold-and-thrust belt that was subsequently folded (Dover, 1994). Similar deformation continues to the southwest in rocks of the Minchumina terrane and is also interpreted to date from this time interval. The Livengood and other small terranes in this area may represent a part of the North American continental margin that has been translated northwestward along the Tintina Fault, possibly from the Mackenzie Mountains fold belt in the early Cenozoic (Beaudoin and others, 1994; Dover, 1994).

\section{LM2e Time Slice, Extensional Deformation}

LM2e penetrative extensional deformation is exposed across widespread areas of northern and central Alaska (fig. 18, table 1). The deformation is expressed as penetrative extensional fabrics with greenschist mineral assemblages that deform older metamorphic fabrics. In the Seward Peninsula, LM2e fabrics are gently dipping with north-south to northwestsoutheast-stretching lineations (fig. 18). These fabrics are synkinematic with 90 Ma magmatic rocks and represent extensional exhumation between 90 and 82 Ma (Dumitru and others, 1995). The deformation is accompanied by Barrovian series metamorphism that varies from low grade to granulite facies.

In the southern Brooks Range, LM2e deformation is represented by a prominent, locally mylonitic and phyllonitic, south-dipping foliation that transitions southward into brittle extensional fabrics adjacent to and in the Angayucham-Tozitna-Innoko terrane (Gottschalk and Oldow, 1988; Little and others, 1994; Moore and others, 1997). The extensional fabrics display down-to-the-south kinematics (fig. 18) (Gottschalk and Oldow, 1988; Little and others, 1994; Vogl, 2002; Toro and others, 2002), although top-to-the-north extension on the northern flank of the metamorphic core of the Brooks Range was also reported by Toro and others (2002). Isotopic ages indicate that extensional exhumation occurred between 103 and $98 \mathrm{Ma}$ (Vogl, 2002) in the south-central Brooks Range and 113 Ma in the southeastern Brooks Range (Blythe and others, 1996).

LM2e deformation in the Yukon-Tanana Upland is expressed as subhorizontal penetrative fabrics with top-to-the-southeast kinematics (fig. 18) and greenschist to amphibolitefacies metamorphism at low structural levels and localized mylonitic shear zones at higher structural levels (Pavlis and others, 1993). As much as $10 \mathrm{~km}$ of crustal section was removed on at least one mylonitic shear zone (Pavlis, 1989; Pavlis and others, 1993). Along the northwestern margin of the Yukon Composite terrane, deformational fabrics diminish or disappear against the sedimentary Wickersham-White Mountains terrane at a contact that has been variously interpreted as being transitional, a thrust fault, or an extensional fault (Pavlis and others, 1993).

Dating of micas in these fabrics in the Yukon Composite terrane by K-Ar and ${ }^{40} \mathrm{Ar} /{ }^{39} \mathrm{Ar}$ have yielded ages of $111-107 \mathrm{Ma}$, whereas ${ }^{40} \mathrm{Ar} /{ }^{39} \mathrm{Ar}$ hornblende ages from amphibolites are 135-115 Ma (Pavlis and others, 1993; Dusel-Bacon and others, 2002). Plutons dated at 113-111 Ma are thought to be synkinematic with the deformation (Dusel-Bacon and others, 2002); slightly younger but post-tectonic caldera complexes in Alaska and the Yukon yield 110-108 Ma ages (Mortensen and Dusel-Bacon, 2014). Pavlis and others (1993) suggested that extensional exhumation initially may have begun slowly, increased to a maximum at 116-114 Ma, and ended by $110 \mathrm{Ma}$. Although the extensional deformation in the Yukon Composite terrane, 
which seems to have been most intense at about 116 to $110 \mathrm{Ma}$, clearly crosses the boundary between our LM1 and LM2 age bins (fig. 1), we have classified it as LM2 to emphasize the younger part of its age range.

LM2e deformation in the Kuskokwim and Ray Mountains (Ruby structural high) is less well understood and may be poorly expressed or absent in some places. However, structural contacts that place less metamorphosed rocks of the Angayucham-Tozitna-Innoko terranes onto Ruby terrane schists are widespread and imply that an episode of extensional faulting cut out a structural section that once existed between these terranes following thrust emplacement in LM1 time. In the Kokrines Hills, granitic rocks dated at 113-112 Ma truncate this contact (Roeske and others, 1995, 1998). The Melozitna pluton, dated at 118 to 114 Ma may be synkinematic with respect to extensional fabrics associated with the contact (Roeske and others, 1995, 1998, 2015; Tuzzolino and others, 2014).

These relations present two dilemmas for classification of LM2 deformation in this area. The first dilemma concerns the limits of the distribution of the middle-Cretaceous penetrative extensional deformation because its distribution in the Ruby terrane presently is not constrained beyond the studied areas in the western Kokrines Hills. Middle-Cretaceous extensional deformation has not been recognized south of the Kaltag Fault in the Kaiyuh Mountains (Roeske and McClelland, 1997) nor in the Ray Mountains northeast of the Kokrines Hills (Dover, 1994), although the results in both areas need to be more fully assessed. Roeske and others (1998) suggested that extension in the Kokrines Hills was caused by transtensional faulting parallel to the Ruby structural high prior to initiation of sedimentation in the adjacent Kobuk-Koyukuk Basin and, thus, is limited to the northwestern margin of the Ruby terrane. On the other hand, the structural relations of mainly brittly deformed, mostly low-grade oceanic volcanic and associated sedimentary rocks of the ATI terrane, structurally above the ductilely deformed blueschistfacies-bearing continental rocks of the Ruby terrane, are similar to those found in the extended parts of the southern Brooks Range, Seward Peninsula, and Yukon Composite terrane (Miller and Hudson, 1991). The lack of detailed study of these contacts and fabrics in most areas, coupled with the ductile extensional relations known to be present in the Kokrines Hills, suggest that low-angle extensional contacts and associated fabrics may be more widespread than previously recognized. In deference to the few studies that have been published, we show penetrative extension as being limited to only the area of the western Kokrines Hills in figure 18, but indicate that it is suspected elsewhere across most of the Ruby terrane.

As with the Yukon Composite terrane, the second dilemma involves whether to assign the extensional deformation in the Kokrines Hills to the LM1 or LM2 time-slice interval. A ${ }^{40} \mathrm{Ar} /{ }^{39} \mathrm{Ar}$ white mica age from a shear zone at the structural contact of the ATI on the Ruby terrane in the Kokrines Hills and U-Pb ages from the pluton that postdate the shearing both approximate $113 \mathrm{Ma}$ (Roeske and others, 1998), the boundary between the two age intervals, whereas dating of another extensional shear zone yielded a ${ }^{40} \mathrm{Ar} /{ }^{39} \mathrm{Ar}$ age of $109 \mathrm{Ma}$ (Roeske and others, 1995). If the extensional fabrics are present regionally along the contact between the Ruby and ATI terranes, however, the deformation must predate the widespread, mostly 113-111 Ma emplacement age of the voluminous granitic rocks that truncate the contact (Roeske and others, 2015).

For this study, we chose to assign the extensional deformation to LM2 because this is its youngest possible age and to draw attention to the wide distribution of broadly middleCretaceous extensional deformation in interior Alaska shown in figure 18. Nonetheless, it is important to recognize that, as presently dated, extension in the Kokrines Hills is as much as 28 
m.y. older than that dated in the Seward Peninsula and southern Brooks Range, and may have begun or occurred prior to 113 Ma (late in LM1 time).

LM2e deformation in the Seward Peninsula, southern Brooks Range, and Kuskokwim and Ray Mountains is thought to have formed during exhumation following LM1 arc-continental collision along the Arctic margin of North America, whereas LM2e fabrics in the Yukon Composite terrane formed during the exhumation that followed EM2 deformation along the Cordilleran margin of North America.

\section{LM3 Time Slice-Late Late Cretaceous (Santonian-Maastrichtian) (86-66 Ma) Deformation}

Late Late Cretaceous deformation (LM3) is widespread across much of southern and western Alaska (fig. 19; table 1).

In the Chugach Mountains of southeastern Alaska, south- to southeast-vergent fold and thrusts (fig. 19) record the accretion of turbiditic deposits (Valdez Group of the Chugach terrane) during subduction of the paleo-Pacific Ocean along the southern margin of Alaska. The turbidites were probably deposited in the trench or offscraped from subducting oceanic crust and emplaced into the accretionary prism that formed the forearc of the Peninsular terrane. These strata were deposited and accreted during Campanian and Maastrichtian time (84-66 Ma; Trop and Ridgway, 2007; Amato and others, 2013).

Across central and western Alaska, LM3 deformation is mostly expressed as tight and locally overturned folds and thrust faults that deform early Late Cretaceous basinal strata in and flanking the Kahiltna, Kuskowkim, Lower Yukon-Koyukuk, and Kobuk-Koyukuk Basins. Deformation affected at least the margins of the older basin-bounding terranes (except the Brooks Range portion of the Arctic Alaska terrane) but is absent or difficult to distinguish from earlier or later deformations in the bounding terranes away from the basin margins.

In the Kahiltna Basin in the western Alaska Range, early Late Cretaceous strata with detrital zircons as young as $85 \mathrm{Ma}$ are deformed and are crosscut by post-tectonic plutons of $75 \pm$ 5 Ma (Hults and others, 2013; Box and others, 2013). Fossil ages of strata unconformably overlying deformed Kahiltna strata range from Coniacian-early Campanian (Trop and others, 2004) in the central Alaska Range to Albian-early Cenozoic (Hampton and others, 2007) in the Talkeetna Mountains, with Kahiltna deformation timing interpreted by these authors as LM3 and LM2, respectively. In the western Alaska Range, folds of Kahiltna Basin strata verge in opposite directions away from the central basin axis and involve the underlying older strata in the flanking Farewell and Peninsular-Wrangellia terranes (fig. 19; Box and others, 2013). Farther east in the central Alaska Range, fold and thrust deformation involving older strata within the basin (Hampton and others, 2007; Gilman and others, 2009) is more complex, ranging from southeast vergent (Ridgway and others, 2002; Davidson and McPhillips, 2007; Gilman and others, 2009) to northwest vergent (O’Neill and others, 2003; Hampton and others, 2007). These structures are further complicated by refolding by Cenozoic folds and thrusts having the same vergence (Ridgway and others, 2002; Trop and others, 2004).

Deformation in the Kuskokwim Basin is also complex. Basement-involved, northwestverging folds and thrusts occur only in the southwest (Box and others, 1993). Farther north, Kuskokwim strata are deformed into dominantly northeast-trending thin-skinned folds, which locally are refolded by thin-skinned, northwest-striking, southwest-verging folds and thrusts in the central and northeastern part of the Kuskokwim Basin (Patton and others, 1980; Miller and Bundtzen, 1994). The southern part of the Kuskokwim Basin is deformed into arcuate folds that are convex to the southwest. These folds may reflect southwest-verging LM3 refolding of earlier 
LM3 folds. Deformed Upper Cretaceous Kuskokwim strata are unconformably overlain by volcanic strata and crosscut by coeval granitic plutons with Ar-Ar ages as old as $74 \mathrm{Ma}$ (Box and others, 1993; Miller and Bundtzen, 1994).

In the Lower Yukon-Koyukuk Basin, strata as young as Turonian are deformed in an arcuate east-southeast-verging fold and thrust belt (Cushing and Gardner, 1987; Patton and others, 2009) that may root to the west beneath the Arctic Alaska terrane in the eastern Seward Peninsula (fig. 19). Kobuk-Koyukuk Basin strata, locally with underlying basement rocks of the Koyukuk and Angayucham-Tozitna-Innoko terrane, are deformed into moderately tight folds trending in an arcuate pattern from northeast-trending in the southern part, to north-trending in the east-central part, to west-trending in the northwestern part (Patton and others, 2009), crudely paralleling the southeastern and northern flanks of the basin (Ruby terrane and Brooks Range, respectively). The deformed strata are unconformably overlain by volcanic strata and intruded by hypabyssal rocks with K-Ar ages as old as $69 \mathrm{Ma}$ (Patton and Moll-Stalcup, 1996). Open folding of metamorphic foliation in the Ruby terrane, which affected metasedimentary schists as well as granitic gneisses with igneous ages as young as $118 \mathrm{Ma}$ (Roeske and others, 1995), is parallel to folding of adjacent Upper Cretaceous strata; however, the timing constraints on the folding are poor and it may pre- or postdate folding of adjacent basinal strata.

The distribution, character, and kinematics of LM3 deformation across Alaska suggests it was controlled by convergence and overthrusting of deeper, more rigid basement blocks along detachments that surface into both basement-involved and thin-skinned folds, and thrusts within the thick Cretaceous basin strata.

\section{C1 Time Slice-Paleocene and Eocene (66-34 Ma) Deformation}

Deformation of early Paleogene age (C1) is found in virtually all parts of Alaska except for the Seward Peninsula, much of southwest Alaska, and the Talkeetna and Wrangell Mountains (fig. 20, table 1). Early Cenozoic deformation across Alaska can be divided into three general belts with distinct characteristics: a southern area of accretionary deformation in the Pacific margin forearc, a central area of relatively gentle folding with generally northeasterly trends, and a northern area of north-directed, thick-skinned thrusting with a frontal zone of thin-skinned detachment folding.

Early Paleogene (C1) deformation in southern Alaska consists of steeply north-dipping slaty cleavage and structurally incoherent folding and faulting in Paleogene accretionary units (Orca Group). Structural vergence is seaward and indicative of formation during accretion (Plafker and others, 1994). In older parts of the subduction complex (Chugach terrane), C1 deformation consists of a diffuse network of brittle, generally south-vergent thrusts and relatively younger dextral and sinistral faults that deform older accretion-related structures (Kusky and others, 1997a; Haeussler and others, 2003). In the eastern part of the Chugach terrane, postaccretionary fabrics consist of shallow-dipping foliations and recumbent to inclined folds that record top-to-the-east extensional shear and are overprinted by upright folds with steeply dipping and orogen-parallel cleavage (Pavlis and Sisson, 1995; Scharman and others, 2011; Gasser and others, 2011). The fabrics are synmetamorphic in medium-pressure/high temperature schists and gneisses (Chugach Metamorphic Complex) dated at 55-51 Ma. The deformation and metamorphism of the subduction assemblage is thought to result from ridge subduction and subsequent transition to orogen-parallel dextral translational deformation in later C1 and C2 time (Bradley and others, 2003b). 
C1 shortening is indicated by folding in the Matanuska Valley and the southern Wrangell Mountains, the forearc basin of the early Tertiary Alaska Range volcanic arc. Folded uppermost Cretaceous (Maastrichtian) strata are unconformably overlain by Paleocene strata in the Matanuska Valley. These Paleocene and Eocene strata are also progressively tilted and folded by reverse faulting on the Castle Mountain Fault during deposition (Trop and others, 2003). This C1 deformational belt continues to the east into the southern Wrangell Mountains (Trop and others, 2003). Broad long-wavelength, low-amplitude folds (dips generally $<30^{\circ}$ ) of early Paleocene (C1) age are recognized in the Yukon-Tanana upland, Kuskokwim and Ray Mountains, the Kobuk-Koyukuk, Kuskokwim, and Kahiltna Basins, and the Livengood area, and record relatively minor amounts of northwest-southeast oriented shortening. In the Yukon Composite terrane, broad upright folds warp foliation (Hansen and Dusel-Bacon, 1998) and deform Upper Cretaceous-Lower Tertiary strata deposited unconformably on the metamorphic rocks (Cushing and Foster, 1984; Foster and Cushing, 1985). Fission track ages suggest the deformation occurred at $\sim 40 \mathrm{Ma}$ (Dusel-Bacon and Murphy, 2001). The Kanuti folds along the western margin of the Ruby structural high are a large-scale east-northeast-trending anticline-syncline pair that folds early Paleogene volcanic rocks and the rocks of the Angayucham-Tozitna-Innoko and Ruby terranes that underlie them (Patton and others, 2009). Along the Kaltag Fault west of Livengood, the large-scale east-northeast-trending Sawtooth Mountain antiform folds middleCretaceous (LM2c) thrust faults and is intruded by $\sim 60$ Ma granitic rocks (Dover, 1994). In the Kahiltna, Kuskokwim, and southern Kobuk-Koyukuk Basins and surrounding areas, latest Cretaceous to earliest Tertiary volcanic fields are commonly preserved in the cores of gentle northeast-trending synclines that parallel earlier, tighter LM3 folds. The orientation and scale of these structures are similar to those of the Mount Doonerak antiform in the central Brooks Range, which seismic data show is a crustal-scale duplex that roots in a detachment in the middle or lower crust (Fuis and others, 2008). This suggests that most or all of the northwest-vergent, early Cenozoic long-wavelength folds in interior Alaska may have been constructed by duplexing along faults that emanate from similarly deep levels of detachment under Alaska.

Early Cenozoic deformation having a different trend is present in the western Ogilvie Mountains north of the Tintina Fault, where northeast-trending, southeast-vergent folds and thrust faults postdate Early and Late Cretaceous (LM1 and LM2c) structures. These folds and thrusts deform Campanian to Eocene strata and appear to predate or are synchronous with movement on the Tintina Fault (Dover, 1992). The deformation is probably related to northtrending folds that deform strata as young as Santonian to the east in the Eagle Plains in the Yukon (Lane, 1998). The deformation there is east-directed, with divergence of the trends between east-central Alaska and the Eagle Plains here interpreted as caused by the influence of older northeast-trending LM1 thrusts present along the passive margin of the North America.

In northern Alaska, C1 deformation is represented by significant shortening in the northvergent, east-west-trending late Brookian fold-and-thrust belt (fig. 20), which is superposed on the Early Cretaceous (LM1) early Brookian thrust system and forms the modern Brooks Range (Moore and others, 2004). The late Brookian deformation consists of a system of spaced, basement-involved thrusts that deform the older Early Cretaceous (LM1) early Brookian thrust belt and metamorphic hinterland. To the north, the deformation has advanced past the deformation front of the early Brookian orogen into the Colville foreland basin, which lies to the north. In the Colville Basin, deformation produced a valley-and-ridge-style fold belt on a detachment that lies near the base of the foreland basin succession (Moore and others, 2004). The transition between the late Brookian thrust and fold belts is marked by a prominent triangle 
zone along the southern margin of the foreland basin (Moore and others, 2004; Duncan and others, 2012). An arcuate system of thrusts uplifted the northeastern Brooks Range, which spans the international border in northeastern Alaska (Lane, 1998) and constitutes the northeastern salient of the Brooks Range. The age of the deformation is constrained by widespread $\sim 60 \mathrm{Ma}$ fission-track ages (for example, Blythe and others, 1996; O’Sullivan, 1996; O’Sullivan and others, 1997, 1998a,b) and by a regional sub-late Paleocene sequence-bounding unconformity that postdates deformation on the North Slope (Mull and others, 2003). Uplift was sufficient to cause denudation of the entire thickness of the Colville Basin except for a small remnant at Bathtub Ridge in the northeastern Brooks Range (fig. 20).

The organization and trends of many C1 structures suggest that a detachment deep in the crust may have extended from the subduction zone in southern Alaska across interior Alaska to the Brooks Range in the early Cenozoic (Fuis and others, 2008). Large-scale low-amplitude folds across much of interior Alaska could represent minor splays or ramps in an otherwise regional flat in the detachment. In this interpretation, shortening daylights in the Brooks Range because of the presence of stronger crust in Arctic Alaska, producing a basement-involved style of thrustdominated deformation where it ramps to shallower levels in the Brooks Range and to an even shallower level of detachment and a thin-skinned style of deformation to the north in the Colville Basin. The north-directed deformation probably represents retroarc thrusting related to northward subduction in southern Alaska (Fuis and others, 2008). This explanation, however, does not easily explain the east and southeast-directed deformation in the western Ogilvie Mountains and the Eagle Plains to the east in the western Yukon Territories nor does it factor in Cenozoic right slip on the Tintina, Denali, and other faults in southern and interior Alaska.

\section{C2 Time Slice-Oligocene and Early Miocene (34-15 Ma) Deformation}

Oligocene and early Miocene (C2) contractional deformation is recognized in northeastern Alaska, where it includes relatively young contractional structures in the Brooks Range, and along the Denali Fault in the central Alaska Range (fig. 21, table 1).

North-directed basement-involved thrusting in the frontal part of the northeastern Brooks Range culminates to the north near the present-day coastline in a northeast-trending triangle zone (Marsh Creek anticline) that deforms Miocene and older strata (O’Sullivan and Wallace, 2002; Potter and others, 2004). Fission track data from this part of the Brooks Range indicate upliftrelated cooling occurred at $27 \mathrm{Ma}$ (O’Sullivan and Wallace, 2002). Seismic reflection data show that the frontal part of the deformational belt emanates from a basal detachment lying at a depth of about $8 \mathrm{~km}$ on the coastal plain (for example, Moore, 1999; Potter and others, 2004) and continues to the northeast offshore as the subsurface Beaufort fold belt (Lane, 1998). In the offshore area, the fold belt prograded across the continental margin, down the continental slope and into the Canada Basin to the north on a detachment in Cretaceous shale, and terminated in a series of detachment folds in basin-plain deposits of the Canada Basin (for example, Helwig and others, 2011).

Farther south in the Brooks Range, C2 deformation is recognized in the crustal-scale northeast-trending Mount Doonerak antiform in the central Brooks Range. Although the antiform is largely a Paleogene structure, a late phase of construction is indicated by fission-track ages of $24 \mathrm{Ma}$ (O’Sullivan and others, 1998a). This structure is underlain by a detachment at a depth of about $30 \mathrm{~km}$ and represents hinterland deformation linked to C2 deformation in the coastal plain area of the northeastern Brooks Range (Moore and others, 1997; Fuis and others, 2008). 
In the Alaska Range, Trop and others (2004) documented south-southeast-directed thrust faults associated with Oligocene syntectonic sedimentation adjacent to the right-lateral Denali Fault (Colorado Creek Basin, fig. 21). They inferred that the deformation was transpressional, perhaps because of a local stepover or splay fault that formed as part of the Denali Fault System. Regional uplift centered in that same area beginning at $30 \mathrm{Ma}$, and gradually younging to $18 \mathrm{Ma}$ within $200 \mathrm{~km}$ to the east and west, is indicated by detrital thermochronology of stream sediments shed from the Alaska Range (Lease and others, 2016). The uplift and associated transpressional deformation were interpreted to reflect far-field deformation that occurred during the early phase of emplacement of the Yakutat microplate against southern Alaska $600 \mathrm{~km}$ to the south-southeast.

\section{C3 Time Slice-Late Miocene to Holocene (150 Ma) Deformation}

Late Miocene to Holocene (C3) contractional deformation is observed in southern Alaska and in northeasternmost Alaska and adjacent Beaufort Sea continental margin (fig. 22, table 1).

Late Miocene to Holocene (C3) contractional deformation in southern Alaska is related to the northwest-directed subduction and collision of an oceanic plateau and thick overlying section of sedimentary deposits (Yakutat terrane, block, or microplate) with the North American margin beneath the St. Elias orogen in southern Alaska (Plafker and others, 1994; Pavlis and others, 2004; Worthington and others, 2012). This orogen developed beginning at 12-10 Ma in a "tectonic corner" along the transition from subduction to transform tectonics at the northeastern end of the Aleutian subduction zone (Pavlis and others, 2004). Seismic data, however, show that that the Yakutat microplate extends as a flat slab for $\sim 250 \mathrm{~km}$ toward the northwest beneath Alaska (Ferris and others, 2003; Eberhart-Philips and others, 2006; Fuis and others, 2008; Bauer and others, 2014), which implies that collision may have begun much earlier, in the Oligocene or earlier time (Finzel and others, 2011). The change from right-slip to contractional tectonics from Canada into central Alaska along the southern Alaska margin has produced areas of right transpression in the Alaska Range and Cook Inlet (Haeussler, 2008).

Deformation at the surface is expressed as a fold-and-thrust belt in the Chugach and St. Elias Mountains and by folding and thrusting in the Alaska Range southward into the Susitna Basin and perhaps the Tordrillo Mountains (Haeussler, 2008). Much of the region between the Alaska Range and the St. Elias Range and adjacent Chugach Mountains displays mainly passive uplift without evidence of significant contractional deformation (Arkle and others, 2013). An exception is in Cook Inlet and northeastward into the Matanuska Valley where a mainly submerged or covered transpressional fold belt is present (Haeussler, 2008).

The frontal part of the St. Elias orogen is a northeast to east-west-trending thin-skinned, south-vergent fold and thrust belt that extends southwestward offshore as the Pamplona zone, which forms the northeastern part of the Aleutian subduction zone. To the north, folds become increasingly complex northward and pass into a zone of imbricate thrusting. The imbricated zone lies below the north-dipping Chugach-St. Elias Fault, which forms the suture between the Yakutat microplate and the Paleogene and Cretaceous parts of the southern Alaska subduction complex (Wallace, 2008; Pavlis and others, 2012). The fold-and-thrust belt occupies the tectonic position of the Neogene accretionary prism associated with the Aleutian subduction zone on strike to the southwest. These structures probably transition into accretionary structures and relatively younger megathrust splay faults that are exposed on the islands at the entrance to Prince William Sound (Haeussler and others [2015]) and probably occur onshore to the northeast into the Cordova area judging from the similar topographic expression in this area. 
In the Alaska Range to the northwest, late Miocene to Holocene (C3) shortening deformation is present. The deformation caused uplift of the Alaska Range since about 7-6 Ma (Lesh and Ridgway, 2007; Haeussler, 2008; Benowitz and others, 2011, 2012; Lease and others, 2016) and formed thrust belts north and south of the Denali Fault with differing characteristics and structural vergence. North of the fault in the northern foothills of the Alaska Range, deformation is expressed as a generally north-directed, basement-involved, fold-and-thrust belt. Modeling of the deformation by Bemis and Wallace (2007) suggests the fold-and-thrust belt has a passive-roof duplex-style, including both south and north vergent thrusts and a south-dipping basal detachment at a depth of $\sim 6-9 \mathrm{~km}$ in basement (Bemis and Wallace, 2007; Bemis and others, 2012). Stratigraphic relations show that the shortening is relatively low-magnitude and high-relief style and developed since $3 \mathrm{Ma}$. The deformational belt is arcuate and approximately parallel with convex-northward curvature of the Denali Fault (Bemis and others, 2012).

In contrast, deformation south of the fault consists of broadly spaced southwest-trending thrust faults that splay away from the Denali Fault (Haeussler, 2008). This system of faults is poorly mapped but includes the previously unknown southeast-directed Susitna Glacier Fault on which the 2002 M7.9 Denali Fault earthquake occurred. Other southeast-directed thrust faults with similar trends have been recognized and are interpreted to truncate Quaternary strata along the northern flank of the Susitna Basin (Peters Hill Basin) (Stanley and others, 2014). The high topography of the central Alaska Range was exhumed since $6 \mathrm{Ma}$ and was likely constructed principally on this system of faults (Bemis and Wallace, 2007). Lease and others (2016) documented time-transgressive cooling ages from 12 to $6 \mathrm{Ma}$ from west to east at Denali (formerly Mount McKinley) that suggest progressive rock uplift as the crust south of the Denali Fault moved through a $20^{\circ}$ restraining bend in the fault. Although fission-track data indicate the nearby Tordrillo Mountains were exhumed beginning at about $23 \mathrm{Ma}$, rapid exhumation of the Tordrillos and the Alaska Range was underway by 6-7 Ma (Haeussler, 2008; Benowitz and others, 2011, 2012). This area may have been uplifted on a poorly known series of generally north-trending thrust and (or) reverse faults that deform Susitna Basin just to the east (Stanley and others, 2014).

Numerous northeast-trending fault-propagation folds are present in the subsurface of Cook Inlet and were formed no earlier than Pliocene-Pleistocene time (Haeussler and others, 2000). The folds are discontinuous, asymmetric, doubly plunging, and variable in vergence, amplitude, and wavelength. Associated faults dip steeply into basement beneath the Tertiary sedimentary fill of Cook Inlet. The deformation is caused by dextral transpression, contraction, and southwestward escape of the Cook Inlet Basin strata caught between basement blocks driven northwestward by the collision of the Yakutat block (Haeussler and others, 2000; Bruhn and Haeussler, 2006).

The region between the St. Elias Range and the Denali Fault ("the southern Alaska block") is thought to be currently rotating clockwise about a pivot point near the southern end of Montague Island (Haeussler, 2008). The rotational motion in this part of Alaska may be driven by the collision of the Yakutat microplate with North America in the St. Elias Range, causing right slip along the Denali Fault to the north, extensive uplift and exhumation in the central Alaska Range adjacent to the fault, and transpressional deformation between the Alaska Range and Cook Inlet. The transpression may not deform areas having strong crust, such as the Talkeetna and Tordrillo Mountains, but these areas may form blocks that are carried along by the rotation, compressing intervening areas having weaker crust (for example, the Susitna Basin) 
parallel to the direction of maximum compression. The rotation produces a region of tectonic extrusion to the southwest, which may dominate the southern part of Alaska.

Far-field effects of the collision of the Yakutat terrane with the southern margin of North America may have driven Neogene deformation and seismicity in the northeastern Brooks Range and eastern Beaufort Sea (Grantz and May, 1983; Grantz and others, 1987; Moore and others, 1994b; Mazzotti and Hyndman, 2002). In northeastern Alaska, north-vergent folding and thrusting propagated northward from the northeastern Brooks Range onto the adjacent shelf and slope of the Beaufort Sea, beginning in the late Oligocene to middle Miocene (C2 time, fig. 21), and constructed large-scale folds and a series of detachment folds offshore. The youngest known uplift on one large-scale structure, the Camden anticline, is documented as basal Pliocene (younger than $5 \mathrm{Ma}$ ) (D. Houseknecht, U.S. Geological Survey, written commun., 2015). In addition, faults that offset the seafloor were reported across a wide part of the Alaskan Beaufort Shelf by Grantz and others (1987, their fig. 21.4) suggesting that late Cenozoic deformation is probably present across much of the Beaufort shelf to the east of the Camden anticline.

At regional scale, the area of late Cenozoic deformation in northern Alaska appears to be bounded by a north-trending zone of left-lateral seismicity in Camden Bay on the west and by a zone of right-lateral seismicity in the Richardson Mountains and Mackenzie Valley in the Yukon Territories on the east (Grantz and others, 1987; Mazzotti and Hyndman, 2002). These zones of seismicity may represent tear faults that mark the limits of an aerially extensive wedge of lowmagnitude north-vergent convergent deformation that straddles the United States-Canada border and affected much of northeastern Alaska.

\section{Synopsis of Regional Structural Histories and Their Tectonic Interpretations}

In this section, we briefly sketch the structural histories of parts of Alaska by region. These regions are generally defined by geographic features (fig. 2) and the terranes they encompass (fig. 4). These regions are the Brooks Range and North Slope (most of Arctic Alaska terrane), Seward Peninsula (SW Arctic Alaska terrane), the Ray Mountains-Kokrines HillsKaiyuh Mountains (Ruby terrane), western Ogilvie Mountains (Porcupine terrane), Nulato HillsKoyukuk River Basin (Koyukuk terrane), Kuskokwim Mountains-Alaska Range (Farewell terrane), Yukon-Tanana upland (Yukon Composite terrane), Alaska Peninsula-Eastern Alaska Range-Talkeetna/Wrangell Mountains (Alexander, Wrangellia, and Peninsular terranes), and Chugach Mountains (Chugach, Prince William, and Yakutat terranes). These regions are grouped into Northern, Interior, and Southern regions for discussion. Only references that are not given earlier in the text or tables are given here. A preliminary version of the tectonic interpretation of these structural histories is also given here. For a more thorough consideration of the structural histories and their implications for the tectonic assembly of Alaska, the reader is referred to Moore and Box (2016).

\section{Northern Region}

\section{Brooks Range and North Slope (Arctic Alaska Terrane)}

The oldest episode of deformation known in northern Alaska is represented by Neoproterozoic penetrative deformation in the southwestern Brooks Range (time slice P3, fig. 10). Whether and how far this deformation might extend beyond its single area of exposure is 
unknown. Several authors (Dumoulin and others, 2002; Amato and others, 2009; Till and others, 2014) suggested that the early Paleozoic and Neoproterozoic strata in this part of the Arctic Alaska terrane correlate with coeval parts of the Baltic craton, although the nature of their underlying basement rocks is unknown.

The Devonian Romanzof orogeny is recognized mainly in the northeastern Brooks Range and can be traced in seismic data across most of the North Slope (time slice EP3, fig. 11). The deformation consists of Devonian north-vergent folds and thrust faults that represent significant shortening. There is no evidence of Devonian deformation within the metamorphic hinterland or the far-travelled allochthons of the Brooks Range to the south.

If the effects of Cretaceous counterclockwise rotational opening of the oceanic Canada Basin (Grantz and May, 1983; Embry, 1990) are removed and Arctic Alaska is rotated back against the Canadian Arctic margin, the Romanzof orogen aligns with the south-vergent Late Devonian-Mississippian Ellesmerian orogen (Gottlieb and others, 2014), although some authors (Lane and others, 2016) disagree, noting the Romanzof orogen may be older than the Ellesmerian orogen. Assuming the orogens are related, the combined Romanzof-Ellesmerian orogens may record the collision of Baltic-affinity crust with the northern margin of Laurentia in the Devonian (Moore and Bird, 2009; Beranek and others, 2010; Anfinson and others, 2012).

The early phase of the Brookian orogeny led to the present framework of the ArcticAlaska terrane. Deformation was initiated within the Angayucham-Tozitna-Innoko terrane in Late Jurassic (EM3, fig. 15) with penetrative deformation and high-temperature metamorphism of basalts and quartzose sediment below the contact with the mafic and ultramafic plutonic base of the Brooks Range ophiolites. The deformation at the base of the ophiolites is interpreted as an early phase of subduction of materials from a downgoing oceanic plate against forearc crust of the adjacent Koyukuk arc terrane (Patton and Box, 1989). These ophiolites have geochemical characteristics of supra-subduction-zone ophiolites formed in a forearc setting above subduction zones (Harris, 2004).

In the Berriasian (early Early Cretaceous), the distal continental margin of the Arctic Alaska terrane began to be subducted, producing thrust imbrication of sedimentary cover units as allochthons and, deeper in the subduction zone, subduction metamorphism of the continental basement of the imbricated rocks (LM1, fig. 16). Rotational opening of the Canada Basin to the north and counterclockwise rotation of Arctic Alaska between the Hauterivian and Aptian (Chian and others, 2016) is interpreted to have overlapped in time or followed the subduction-related thrust imbrication. Contractional deformation associated with early Brookian deformation ended between Barremian and early Albian time (Cole and others, 1997), but before ending may have included a period of backthrusting that uplifted the metamorphic rocks of the southern Brooks Range in the late Early Cretaceous (LM2C, fig. 17). The contractional deformation was closely followed by a phase of postorogenic extensional deformation that occurred during the Albian and Cenomanian but may have begun as early as the early Aptian. Shown in the LM2E time-slice map (fig. 18), the extensional deformation produced ductile to brittle extensional structures that transposed earlier LM1 structures across much of the southern part of the early Brookian orogenic belt. The apparent conflict between the timing of backthrusting and extension is yet to be resolved.

About thirty million years following extensional exhumation of the hinterland of the early Brookian deformational belt in the middle-Cretaceous, a second belt of north-directed contractional deformation, here termed the late Brookian deformation, was superposed on the early Brookian deformational belt in the Paleocene and Eocene (C1, fig. 20). In contrast to the 
earlier deformation, late Brookian deformation has a deep-seated basement-involved style of thrusting that terminates to the north in a triangle zone beneath Cretaceous foredeep strata of the Colville Basin. Foredeep strata to the north of the triangle zone are deformed into a belt of detachment folds that affected much of the Colville Basin. Except for the Lisburne Peninsula in the far west, this deformation extended along the length of northern Alaska. To the east, however, the deeper level of detachment for the deformation in the Brooks Range extended much farther north, producing a major salient in the northeastern Brooks Range. The deeply rooted thrusting resulted in exhumation of most of the eastern Colville Basin and underlying Precambrian basement rocks (Wallace and Hanks, 1990). North-vergent shortening deformation continued in the frontal part of the northeastern Brooks Range and to the north in the Beaufort Sea into the Oligocene and Neogene, as shown on the C2 and C3 time-slice maps (figs. 21, 22). This deformation was thin-skinned on the Beaufort shelf and slope but produced large-amplitude folds owing to the large thicknesses of Cretaceous deposits in this area. This C2 and C3 deformation in northeastern Alaska may have been caused by far-field shortening that emanated from the collision of the Yakutat terrane with the southern Alaska margin (Grantz and others, 1987; Moore and others, 1994b).

\section{Seward Peninsula (Southwest Arctic Alaska Terrane)}

Early Paleozoic and Neoproterozoic rocks of the Seward Peninsula, like those in the southern Brooks Range, are interpreted to have originated in the Baltic craton (Dumoulin and others, 2002; Amato and others, 2009; Till and others, 2014). The earliest documented deformational event preserved in the Seward Peninsula is Early Cretaceous penetrative deformation and high-pressure/low-temperature metamorphism, part of the early Brookian deformational belt (LM1, fig. 16). As in the similar rocks of the southern Brooks Range, early Brookian deformation in the Seward Peninsula was followed in the middle-Cretaceous (LM2E: fig. 18) by an important episode of postorogenic extensional exhumation that produced transpositional penetrative structures and greenschist-facies metamorphic assemblages. In contrast to most of Alaska to the east, there appears to be little or no record of Late Cretaceous (LM3) and early Cenozoic (C1) shortening deformation in the Seward Peninsula.

\section{Ray Mountains-Kokrines Hills-Kaiyuh Mountains (Ruby Terrane)}

The deformational history of the uplift in central Alaska that extends between the Ray Mountains in the northeast through the Kokrines Hills to the Kaiyuh Mountains in the southwest has similarities to that in the Seward Peninsula and southern Brooks Range. This uplift is termed here the Ruby structural high, defined by the exposure area of the Ruby metamorphic terrane and the structurally overlying Angayucham-Tozitna-Innoko terrane (fig. 4). As in the southern Brooks Range, the earliest deformational feature is a Late Jurassic, penetrative, amphibolitefacies metamorphic fabric in metabasalts and metachert below the mafic and ultramafic plutonic bases of ophiolite klippe in the Angayucham-Tozitna-Innoko terrane (EM3, fig. 15). The primary deformational feature within the underlying continental Ruby terrane is a ductile, high pressure/low temperature metamorphic fabric, dated as Early Cretaceous (LM1, fig. 16), which records northwest-vergent shortening. The overall similarity of the obduction of oceanic allochthons and blueschist-facies metamorphism of underlying continental rocks to that in the southern Brooks Range leads to a similar interpretation that the deformation occurred during Early Cretaceous subduction of continental crust during the early Brookian orogenic event. However, the structural vergence toward, rather than away from, the adjacent Koyukuk arc 
terrane suggests either the Ruby terrane was subducted to the southeast beneath another arc, or was subducted beneath the Koyukuk arc but subsequently displaced from its initial collisional position (Till and Roeske, 2015).

As with the southern Brooks Range, the Ruby terrane at least locally experienced a phase of postorogenic, top-southeast extensional exhumation (LM2E, fig. 18). Although not yet fully documented, the juxtaposition of allochthons of mostly brittle deformed rocks (AngayuchamTozitna-Innoko terrane) overlying mostly ductilely deformed continental rocks (Ruby terrane) suggests that a crustal section with transitional structural characteristics has been omitted during a phase of postorogenic extensional exhumation. The extensional exhumation of the Ruby structural high, however, appears to be as much as $28 \mathrm{~m}$.y. older than that in the southern Brooks Range and Seward Peninsula. However, the apparent difference in ages may be explained as an artifact of the different dating techniques used to constrain the ages of the deformations. Considered collectively, the period of ductile extension across interior Alaska could be interpreted as lasting from 135 to 90 Ma, as suggested by Miller and Hudson (1991).

There is presently little evidence that the Ray Mountains to Kuskokwim Mountains uplift was involved in the Upper Cretaceous shortening mapped in the flanking Koyukuk-Kobuk and Kuskokwim Basins (LM3 time-slice map, fig. 19). Both flanking areas, however, are marked by early Cenozoic long-wavelength, low-amplitude folds (C1, fig. 20) that also fold the underlying crystalline rocks of the Ruby terrane. Although this folding represents a small amount of shortening that may be less than that of the C1 shortening present in the Brooks Range, the northeast trend of the folds suggests the possibility that the northeast-trending Ruby structural high itself may constitute a regional arch that formed during C1 deformation.

\section{Western Ogilvie Mountains (Porcupine Terrane)}

The deformational history of the western Ogilvie Mountains and adjacent parts of the Porcupine Plateau along the Alaska-Canada border in east-central Alaska is poorly known and controversial. Relations in this area suggest the existence of three significant deformations that hold clues to the linkage between the Arctic geology of northern Alaska and Cordilleran geology in southern Alaska. The oldest deformation recognized is Early Cretaceous thrusting related to the early Brookian deformational event. Early Brookian (LM1, fig. 16) deformation is indicated by the presence of an allochthon composed of oceanic mafic igneous rocks, chert and argillite of the Angayucham-Tozitna terrane (Woodchopper, Circle volcanics) along the Yukon and Porcupine Rivers, and an underlying allochthon composed of distal North American continental margin facies (Porcupine terrane), both of which were thrust eastward onto the Yukon Stable block (that is, Tatonduk block), a part of the North American craton (Churkin and others, 1982). The thrust front for the deformation is indicated by a northeast-trending Early Cretaceous succession (Kandik Group), interpreted as the foreland basin of the orogen.

The second phase of deformation (LM2C, fig. 17) consists of east-west-trending folds and thrusts that continue eastward across the international border into the extensive middle Cretaceous north-vergent Mackenzie Mountains fold and thrust belt, part of the Cordilleran foldand-thrust belt. In Alaska, these structures deform LM1 structures. This second deformational phase is well represented north of the Tintina Fault to latitude $66^{\circ} \mathrm{N}$. and may have extended northward to latitude $67^{\circ} \mathrm{N}$. at the international border as evidenced by sparse east-trending folds there.

The middle-Cretaceous structures are unconformably overlain by a local sedimentary unit (unit TKs) that yields Maastrichtian to Eocene fossils. This unit dips moderately to the southeast, 
which Dover (1992) attributed to postdepositional extensional faulting along the southeastern margin of the unit. Normal faults, however, were not recognized in this area by Brabb and Churkin (1969). We suggest unit TKs is folded by a third regional deformation of southeastvergent system of thrusts and folds that tilted its strata and bent and deflected the LM2C structures into northeastward trends. This deformation is probably related to southeast and eastvergent structures across the border in Canada that deform Santonian-Campanian (Late Cretaceous) strata of the Eagle Basin. Lane (1998) interpreted the age of this deformation as latest Cretaceous-Tertiary and we have assigned it to the C1 time interval (fig. 20). The southeast direction of vergence of these structures (and the eastward vergence of the related structures in Canada) is anomalous with respect to the vergence of C1 deformation in Alaska, but may have reactivated LM1 structures or may have been influenced by the northeast-trending Paleozoic continental margin of North America.

Nulato Hills-Koyukuk River Basin (Koyukuk Terrane)

The Koyukuk terrane is interpreted to represent an intraoceanic island arc, generated by Middle Jurassic to Early Cretaceous subduction of oceanic crust (Box and Patton, 1989). Volcanism waned with subduction of the passive continental margin of Arctic Alaska in late Early Cretaceous time. Its pre-Cretaceous deformational history represents deformation that occurred in an oceanic realm (“Angayucham ocean”) prior to its emplacement against North America. The pre-Cretaceous core of the Koyukuk arc terrane is exposed in the Nulato Hills south of the Kaltag Fault. Middle Jurassic magmatic arc plutons intrude a deformed complex of mafic igneous rocks, chert, limestone, and chert-pebble conglomerate with fossil ages as young as Late Triassic. Little is known of the deformational style, which locally includes greenschistfacies metamorphic fabrics. Uplift of the older complex and its intruding plutons prior to deposition of the Early Cretaceous volcanic arc sequence is recorded in its basal unconformity (Patton and Moll-Stalcup, 1996) and could have been caused by either plateau uplift or a second deformational event during EM2 or early LM1 time.

Late Late Cretaceous (LM3; fig. 19) north-northeast-trending tight folding followed early Late Cretaceous deep basin sedimentation and was followed by broad folding with similar trends in the early Cenozoic (C1, fig. 20).

\section{Interior Region}

\section{Yukon-Tanana Upland (Yukon Composite Terrane)}

Rocks of the Yukon-Tanana upland (Yukon Composite terrane) are mainly polyphase metamorphic rocks that record three penetrative deformational tectonic events, followed by a late folding event. The oldest deformational event is represented by thrust sheets, including ultramafic complexes and other klippe, exposed along the international border emplaced during closure of the Slide Mountain-Seventymile Ocean Basin. Based on evidence for a North American-derived sequence of Triassic age that overlaps the deformation, Beranek and Mortensen (2011) concluded that this first thrust event occurred during the Permian (LP4, fig.13). A second Early Jurassic penetrative deformational event (EM2, fig.14) deformed earlier structures across the entire Yukon Composite terrane. The structural vergence of the EM2 deformation is consistently northwestward, parallel to the trend of the orogen. Although the relatively high pressure metamorphism associated with this deformation appears to support the conclusion of earlier workers (for example, Tempelman-Kluit, 1979; Hansen and Dusel-Bacon, 
1998) that the closure of the Slide Mountain-Seventymile Ocean took place during the Jurassic rather than the Permian deformational event, it is now attributed to backarc thrusting behind a west-facing Triassic to Early Jurassic subduction zone that developed after the collision along the northwestern margin of North America (for example, Dusel-Bacon and others, 2015). The third episode of penetrative deformation records extensional exhumation in middle-Cretaceous (LM2E) time. Although the timing of this event is broadly similar to that of extensional exhumation observed in the Brooks Range, Seward Peninsula, and Ray Mountains-Kuskokwim Mountain uplift, its presence in a terrane linked to the Cordilleran margin suggests exhumation events occurred along both the Arctic and Cordilleran margins of North America at this time. The fourth deformation event (C1, fig. 20) consists of folding of earlier foliations and represents low amounts of shortening that was oriented northwest-southeast to north-south.

\section{Kuskokwim Mountains-Alaska Range (Farewell Terrane)}

Exposed in the Kuskokwim Mountains and the Alaska Range, the Farewell terrane consists of a carbonate-dominated Cambrian to Early Cretaceous stratigraphic sequence that overlies a Precambrian metamorphic basement. It has been interpreted as a crustal fragment of the Proterozoic and early Paleozoic Baltic craton (Dumoulin and others, 2002; Bradley and others, 2014; Malkowski and Hampton, 2014) or as a rifted fragment of the Siberian craton (Blodgett and others, 2010). Its metamorphic basement variably records middle and late Proterozoic deformation events (P2 and P3, figs. 9 and 10) of uncertain tectonic setting. A Permian deformation event (LP4, fig. 13) is recorded in the northern part, represented by a metamorphic fabric overprinting older schists and locally lower Paleozoic carbonate strata. The schists are overlain by a Permian unconformity and conglomeratic units derived from deformed Farewell strata that occur widely to the south. Permian deformation may have been driven by partial underthrusting and collision of the Farewell terrane beneath an oceanic arc terrane on its western (Box and others, 2015) or eastern (Malkowski and Hampton, 2014) flank.

Juxtaposition of the Farewell and Yukon Composite terranes is first constrained by overlap of the Upper Cretaceous Kuskokwim Group strata on the Farewell terrane with clastic sources in the Yukon Composite terrane (Kalbas and others, 2007, 2015). The intervening Minchumina terrane (fig. 4) is overprinted by middle-Cretaceous folding (LM2c, fig. 17) parallel to the margins of the two flanking terranes, which may record the juxtaposition of these three terranes. Late Late Cretaceous (LM3, fig. 19) tight, northeast-trending folding followed early Late Cretaceous deep basin sedimentation and was followed by broad gentle folding in the early Cenozoic (C1, fig. 20).

\section{Southern Domain}

\section{Alaska Peninsula-Talkeetna/Wrangell Mountains (Peninsular, Wrangellia, and Alexander Terranes)}

The Talkeetna and Wrangell Mountains, as well as the eastern Alaska Range and the Alaska Peninsula, expose the Peninsular, Wrangellia, and Alexander terranes, which underlie much of southern Alaska. The Alexander terrane is interpreted as a crustal fragment whose Neoproterozoic and early Paleozoic strata have affinities to the Baltic craton (Gehrels and others, 1996; Beranek and others, 2013). The earliest deformational event is Pennsylvanian deformation (LP3, fig. 12) in the Alexander terrane in the eastern Wrangell Mountains, interpreted to represent its collision with an oceanic arc (Wrangellia terrane) (Beranek and others, 2014). Permian deformation (LP4) is known to be present in the Wrangellia and Alexander terranes in 
Canada and southeast Alaska, but has not been identified in rock units of the map area. Tilting and uplift of Early Jurassic volcanic strata of the Peninsular terrane occurred before development of an angular unconformity in the Middle Jurassic. This deformation may have resulted from an episode of subduction erosion above a north-dipping subduction zone in the late Early Jurassic (EM2) (Clift and others, 2005).

Middle to Late Jurassic deformation (EM3, fig. 11) in the Peninsular and Wrangellia terranes consists of two separate deformational belts that parallel the boundary between the terranes but have opposing vergences. One belt is located along the southern boundary the Wrangellia terrane and includes the northeast-vergent Chitina thrust belt and the penetratively deformed Strelna-Gulkana River metamorphic complexes to the south. The second belt is in the Peninsular terrane south of the boundary with the Wrangellia terrane. This belt consists of the 500-km-long, southeast-vergent Bruin Bay-Little Oshetna reverse fault system. The tectonic cause of these opposed structural belts is uncertain, but if tectonically linked, they would represent the first deformational episode shared by the two terranes. For this reason many authors have suggested the deformations were caused by juxtaposition of the two terranes, possibly along a north-dipping subduction zone, or alternatively, along a transpressional strikeslip boundary having an uncertain sense of offset (Clift and others, 2005; Rioux and others, 2007; Amato and others, 2013).

Early Cretaceous deformation in the Alexander-Wrangellia-Peninsular terrane is thinskinned and southwest-directed in the Nutzotin Basin in the northern Wrangell Mountains (LM1, fig. 12) but has an uncertain structural style southwest of the Totschunda Fault. This basin lies in a backarc position relative to Chisana arc magmatism in the Wrangellia terrane to the south and is deformed by an Early Cretaceous (LM1) southwest-vergent thin-skinned fold belt that is detached near the base of the basin (Berg and others, 1972; Trop and others, 2002; Manuszak and others, 2007). This deformation may record either (1) the onset of collisional interaction of the Alexander-Wrangellia-Peninsular terrane with part of the margin of North America to the northeast (Manuszak and others, 2007), or (2) a period of subduction erosion caused by northdirected subduction along the southern margin of the Alexander-Wrangellia-Peninsular terrane (Amato and others, 2013).

Late Cretaceous (LM3, fig. 19) shortening deformation strongly overprints deep turbidite basin strata on the north flank of the amalgamated Peninsula-Wrangellia terrane. This is generally interpreted to record the collision of the Peninsula-Wrangellia terrane with continental Alaska to the north (Farewell and Yukon Composite terranes) (Trop and Ridgway, 2007; Hampton and others, 2007; Hults and others, 2013). Parallel but much broader early Cenozoic (C1, fig. 20) folds occur in the same region. Regional uplift in the central Alaska Range and a few south-directed thrusts there at about $30 \mathrm{Ma}(\mathrm{C} 2$, fig. 21) are interpreted to be far-field effects of the initial impingement of the Yakutat terrane against southern Alaska (Trop and others, 2004; Lease and others, 2016). Middle Miocene to Recent shortening deformation (C3, fig. 22) within and north of the Alaska Range, within the Susitna Basin, and under Cook Inlet are also interpreted as increasing far-field effects as the Yakutat collision progressed.

\section{Chugach Mountains (Chugach, Prince William, and Yakutat Terranes)}

The Mesozoic and Cenozoic Southern Alaska accretionary complex encompasses all geologic units oceanward of the Border Ranges Fault (Chugach, Prince William, and Yakutat terranes, fig. 4) and includes accreted rocks ranging in age from latest Triassic to Pleistocene. Although previously interpreted to record continuous subduction from Jurassic to Quaternary, 
recent work has shown that the accretionary complex consists of internal packages of accreted strata that were assembled between periods of subduction erosion and (or) ridge subduction events (for example, Amato and Pavlis, 2010). The oldest of the internal packages is a transitional blueschist-greenschist unit, which consist of basalt, chert, argillite, limestone, and ultramafic rocks derived from a downgoing oceanic plate and deformed and metamorphosed during Late Triassic-Early Jurassic subduction (EM2, fig. 14). This unit consists of map-scale blocks and fault slivers along the Border Ranges Fault, which bounds the Peninsular terrane to the north. Following a period of subduction erosion owing to ridge collision between 180 and $170 \mathrm{Ma}$, a second package, which consists of lithic sandstones with Upper Jurassic chert, argillite, and volcanic rocks (Potter Creek assemblage), was accreted by 125 Ma (LM1, fig. 16). After another period of subduction erosion between the Aptian and Albian, a package of trench turbidites consisting of volcanogenic sandstone, conglomerate, and shale (McHugh Creek assemblage) was deposited and accreted in the Cenomanian to Turonian (LM2c, fig. 17). In the later Late Cretaceous, the provenance of the trench deposits changed to plutonic sources, which resulted in deposition of a thick sequence of trench turbidite deposits (Valdez Group) that progressively accreted during the remainder of the Late Cretaceous (LM3, fig. 19).

Accretion of turbidite deposits (Orca Group) continued in early Cenozoic time (C1, fig. 20) along the southern flank of the accretionary complex, outboard of the transpressional Contact Fault. Subduction of a mid-ocean ridge spreading ridge in later Paleocene and Eocene time (late $\mathrm{C} 1)$ led to plutonism and transpressional, dynamothermal metamorphism in the accretionary complex.

Starting at about $30 \mathrm{Ma}$, the Yakutat terrane, composed in part of thick oceanic plateau basalts and moving with the Pacific Plate, began to be subducted along the southern Alaska subduction zone. This resulted in collision of the thickened crust with the North American margin at the Chugach-St. Elias Fault, forming a south-vergent fold and thrust belt beginning about 12-10 Ma (C3, fig. 22) (Pavlis and others, 2004). The collisional zone, which remains active, has built the extremely high topography of the St. Elias Range and is accompanied by active seismicity that has produced far-field affects across much of southern Alaska.

\section{Deformational Domains}

From a tectonic point of view, the maps reveal that the geology of Alaska is divided into three domains having differing tectonic histories that correspond to the geographic regions discussed in the previous section (fig. 23). The Northern domain is overprinted by structures of the Early Cretaceous early Brookian orogeny that were produced by the arc-continent collisional tectonism (Box, 1985; Moore and others, 1994a). This deformation impacted most terranes north of the Tintina and Kaltag Faults and resulted from the subduction of the outboard northern margin of North America beneath oceanic arc or arcs of the paleo-Pacific Ocean. Earlier deformation in the Arctic Alaska terrane records events that brought together continental fragments of Baltica against the Laurentian margin in the Devonian.

The Southern domain encompasses the deformational structures of the Southern region in the previous section, which lies south of the Denali Fault in southern Alaska. This domain includes the Alexander-Wrangellia-Peninsular oceanic magmatic arc terrane and its associated southern Alaska accretionary prism. North of the Border Ranges Fault, the Alexander and Wrangellia arc terranes were amalgamated in the Pennsylvanian, whereas the combined Alexander-Wrangellia terrane was amalgamated with the Peninsular arc terrane during the Late Jurassic. Forearc accretion south of the Border Ranges Fault has occurred episodically since the 
Early Jurassic, interrupted by episodes of subduction erosion, ridge subduction in the Paleogene, and collision with the Yakutat terrane in the Neogene.

The third, Interior domain is roughly bounded by the Denali and Tintina Faults and corresponds to the Interior region in the previous section. This domain is situated between the first two domains and is distinguished by not sharing the pre-Late Cretaceous deformational histories of either domain to the north or south. This domain includes the large Farewell and Yukon Composite terranes, which display temporally distinct episodes of Permian collisional deformation (early Permian Browns Fork and late Permian Klondike orogenies, respectively). A later episode of Early Jurassic deformation affected only the Yukon Composite terrane. Our maps reveal little evidence for final assembly by collisional processes in this domain, although overlapping sedimentary basins indicate that assembly had occurred by the onset of Late Cretaceous time.

The boundary between the Interior and Northern domains is marked for much of its length by important early Cenozoic right-slip translational faults including the Tintina, Victoria Creek, Kaltag, and Poorman Faults. This domain boundary represents a fundamental contact between terranes that experienced the early Brookian orogeny along the northwestern margin of North America to the north and those that did not experience the early Brookian orogeny along the western margin of North America to the south. Although about $450 \mathrm{~km}$ of displacement has been estimated on the Tintina Fault from the stratigraphic similarities of the Livengood terrane with the stratigraphy of northwestern Canada (Gabrielse and others, 2006), the differences between deformational histories of the northern and interior domains are not resolved by restoration of that Cenozoic displacement. Depositional overlap of both the Innoko and Farewell terranes by Upper Cretaceous Kuskokwim Group strata (beginning in Cenomanian during LM2 time) provides the earliest link across this boundary, suggesting that the northern and interior domains were probably juxtaposed by this time.

The Southern and Interior domains are linked by late Late Cretaceous folding and thrusting within the Kahiltna Basin that mark the collision of the Alexander-WrangelliaPeninsular terrane with the Farewell and Yukon Composite terranes to the north. Late Late Cretaceous (LM3) shortening deformation is significant across all of western Alaska north to the south flank of the Brooks Range, probably driven by the collision of the Alexander-WrangelliaPeninsular terrane with the amalgamated continent to the north. The transpressional early Cenozoic deformation represents further consolidation of the Alaskan land mass.

\section{Summary}

Our compilation of contractional and penetrative extensional deformational belts in Alaska reveals that most of the deformational events in Alaska are relatively young features, having developed during Mesozoic and Cenozoic time. The oldest deformations are Precambrian and found in only relatively small parts of Alaska. The oldest deformation recognized anywhere in Alaska is in the basement of the Farewell terrane, which was metamorphosed and deformed starting at about $1.75 \mathrm{Ga}$ (Paleoproterozoic) and again in the Mesoproterozoic and Neoproterozoic. Neoproterozoic deformation has also been reported in the southwestern part of the Brooks Range, although its role in the geology of the composite basement forming the Arctic Alaska terrane is uncertain. These deformations apparently occurred when these terranes were part of a non-Laurentian continental mass.

In general, Paleozoic deformational belts also appear to be restricted to the tectonostratigraphic terranes in which they occur; for example, early Paleozoic deformation to 
the Arctic Alaska terrane (possibly also represented in the Livengood terrane), Pennsylvanian deformation of the Alexander terrane, and Permian deformations of different ages in the Yukon Composite and Farewell terranes. These pre-Mesozoic deformations overprint continental fragments that had earlier disaggregated from a larger continental mass by rifting processes, in some cases with incorporation of oceanic plate materials (Seventymile-Slide Mountain terranes) or intraoceanic arc terranes (Wrangellia).

Beginning in the Jurassic, increasing amalgamation of intraoceanic arc terranes and oceanic plate materials with pre-existing terranes began to take place, including the Late Jurassic assembly of the Peninsular intraoceanic arc and Alexander-Wrangellia terranes along the Strelna-Gulkana River metamorphic and deformational belts, collision of the intraoceanic Koyukuk arc terrane and its forearc oceanic plate materials with Arctic Alaska terranes in the Early Cretaceous, and construction by oceanic plate offscraping of the Jurassic to Neogene southern Alaska accretionary complex. By the Late Cretaceous, much of the framework of Alaska was established, and younger deformation belts developed across rocks of multiple terranes. For example, Late Cretaceous deformation affected rocks in sedimentary basins deposited on a number of the terranes in central, southwestern, and western Alaska and appears to be related to the collision of Alexander-Wrangellia-Peninsular terrane with the previously amalgamated Alaskan subcontinent to the north. Early Paleogene shortening deformation, perhaps because of an episode of ridge-trench collision in southern Alaska, impacted rocks to variable degrees from southern Alaska to the Brooks Range. The late Cenozoic collision of the Yakutat microplate in southern Alaska has produced deformation not only along the margin of southern Alaska, but also across a broad zone from the Alaska Range to Cook Inlet and apparently in northeastern Alaska as well.

\section{Acknowledgments}

We thank Dwight Bradley, Cynthia Dusel-Bacon, Peter Haeussler, Robert Hildebrand, David Houseknecht, Warren Nokleberg, Chris Potter, Sarah Roeske, Richard Stanley, Alison Till and Wes Wallace for discussions about various aspects of the structural geology and tectonics of Alaska. Ric Wilson kindly contributed GIS data that aided this report. Zenon Valin's work on the underlying GIS database for this project is greatly appreciated. This report benefited from the thoughtful reviews of Christopher Potter and Warren Nokleberg. This study was funded by the USGS Mineral Resources, Energy Resources, and National Mapping Programs. 


\section{References Cited}

Amato, J.M., and Miller, E.L., 2004, Geologic map and summary of the evolution of the Kigluaik Mountains gneiss dome, Seward Peninsula, Alaska, in Whitney, D.L., Teyssier, C., and Siddoway, C.S., eds., Gneiss domes in orogeny: Geological Society of America Special Paper 380, p. 295-306.

Amato, J.M., Miller, E.L., Calvert, A.T. Toro, Jaime, and Wright, J.E., 2003, Potassic magmatism on St. Lawrence Island, Alaska, and Cape Dezhnev, northeastern RussiaGeochemistry, ${ }^{40} \mathrm{Ar} /{ }^{39} \mathrm{Ar}$ ages, and implications for the tectonic evolution of the Bering Strait region: Alaska Division of Geological \& Geophysical Surveys Professional Report 120, p. 120.

Amato, J.M., and Pavlis, T.L, 2010, Detrital zircon ages from the Chugach terrane, southern Alaska, reveal multiple episodes of accretion and erosion in a subduction complex: Geology, v. 38, no. 5, p. 459-462.

Amato, J.M., Pavlis, T.L, Clift, P.D., Kochelek, E.J., Hecker, J.P., Worthman, C.M., and Day, E.M., 2013, Architecture of the Chugach accretionary complex as revealed by detrital zircon ages and lithologic variations-Evidence for Mesozoic subduction erosion in south-central Alaska: Geological Society of America Bulletin, v. 125, p. 1891-1911.

Amato, J.M., Toro, J., Miller, E.S., Gehrels, G.E., Farmer, G.L., Gottlieb, E.S., and Till, A.B., 2009, Late Proterozoic-Paleozoic evolution of the Arctic Alaska-Chukotka terrane based on $\mathrm{U}-\mathrm{Pb}$ igneous and detrital zircon ages-Implication for Neoproterozoic paleogeographic reconstructions: Geological Society of America Bulletin, v. 121, p. 1219-1235.

Anderson, A.V., 1991, Geologic map and cross-sections-Headwaters of the Kongakut and Aichilik Rivers, Demarcation Point (A-4) and Table Mountain (D-4) quadrangles, eastern Brooks Range, Alaska: Alaska Division of Geological and Geophysical Surveys, Public-data File 91-3, 23p., 2 sheets, scale 1:25,000.

Anderson, A.V., Wallace, W.K., and Mull, C.G., 1992, Depositional record of a major tectonic transition in northern Alaska-Middle Devonian to Mississippian rift-basin margin deposits, upper Kongakut River region, eastern Brooks Range, in Thurston, D.K., and Fujita, K., eds., 1992 Proceedings International Conference on Arctic Margins: U.S. Department of the Interior Minerals Management Service Alaska Outer Continental Shelf Region, OCS Study MMS 940040, p. 71-76.

Anfinson, O.A., Leier, A.L., Gaschnig, R., Embry, A.F., and Dewing, K., 2012, U-Pb and Hf isotopic data from Franklinian Basin strata-Insights into the nature of Crockerland and the timing of accretion, Canadian Arctic Islands: Canadian Journal of Earth Sciences, v. 49, p. 1316-1328, doi:10.1139/e2012-067.

Arkle, J.C., Armstrong, P.A., Haeussler, P.J., Prior, M.G., Hartman, S., Sendziak, K.L., and Brush, J.A., 2013, Focused exhumation in the syntaxis of the western Chugach Mountains and Prince William Sound, Alaska: Geological Society of America Bulletin, v. 125, p. 776-793.

Avé Lallemant, H.G., and Oldow, J.S., 1998, Antithetic shear and the formation of back folds in the central Brooks Range fold and thrust belt, Alaska, in Oldow, J.S., and Avé Lallemant, H.G., eds., Architecture of the Central Brooks Range Fold and Thrust Belt, Arctic Alaska: Geological Society of America Special Paper 324, p. 253-259.

Bacon, C.R., Foster, H.L., and Smith, J.G., 1990, Rhyolitic calderas of the Yukon-Tanana terrane, east central Alaska-Volcanic remnants of a mid-Cretaceous magmatic arc: Journal of Geophysical Research, v. 95, p. 21,451-21,461. 
Bauer, M.A., Pavlis, G.L., and Landes, M., 2014, Subduction geometry of the Yakutat terrane, southeastern Alaska: Geosphere, v. 10, p. 1161-1176.

Beaudoin, B.C., Fuis, G.S., Lutter, W.J., Mooney, W.D., and Moore, T.E., 1994, Crustal velocity structure of the northern Yukon-Tanana upland, central Alaska-Results from TACT refraction/wide-angle reflection data: Geological Society of America Bulletin, v. 106, p. 9811001.

Bemis, S.E., Carver, G.A., and Koehler, R.D., 2012, The Quaternary thrust system of the northern Alaska Range: Geosphere, v. 8, p. 196-205.

Bemis, S.P., and Wallace, W.K., 2007, Neotectonic framework of the north-central Alaska Range foothills, in Ridgway, K.D., Trop, J.M., Glen, J.M.G., and O’Neill, J.M., eds., Tectonic Growth of a Collisional Continental Margin-Crustal Evolution of Southern Alaska: Geological Society of America Special Paper 431, p. 549-572.

Benowitz, J.A., Haeussler, PJ., Layer, P.W., O’Sullivan, P.B., Wallace, W.K., and Gillis, R.J., 2012, Cenozoic tectono-thermal history of the Tordrillo Mountains, Alaska-PaleoceneEocene ridge subduction, decreasing relief, and late Neogene faulting: Geochemistry, Geophysics, Geosystems, v. 13, no. 4, doi:10.1029/2011GC003951.

Benowitz, J.A., Layer, P.W., Armstrong, P., Perry, S.E., Haeussler, P.J., Fitzgerald, P.G., and VanLaningham, S., 2011, Spatial variations in focused exhumation along a continental-scale strike-slip fault-The Denali fault of the eastern Alaska Range: Geosphere, b. 7, p. 455-467.

Beranek, L.P., and Mortensen, J.K., 2011, The timing and provenance record of the Late Permian Klondike orogeny in northwestern Canada and arc-continent collision along western North America: Tectonics, v. 30, TC5017, , 23 p., doi:10.1029/2010TC002849.

Beranek, L.P., Mortensen, J.K., Lane, L.S., Allen, T.L., Fraser, T.A., Hadlari, T., and Zantvoort, W.G., 2010, Detrital zircon geochronology of the western Ellesmerian clastic wedge, northwestern Canada-Insights on Arctic tectonics and the evolution of the northern Cordilleran miogeocline: Geological Society of America Bulletin, v. 122, p. 1899-1911, doi:10.1130/B30120.1.

Beranek, L.P., van Staal, C.R., Gordee, S.M., McClelland, W.C., Israel, S., and Mihalynuk, M., 2013, Baltican crustal provenance or Cambrian-Ordovician sandstones of the Alexander terrane, North American Cordillera-Evidence from detrital zircon U-Pb geochronology and Hf isotope geochemistry: Journal of the Geological Society of London, v. 170, p. 7-18.

Beranek, L.P., van Staal, C.R., McClelland, W.C., Joyce, N., and Israel, S., 2014, Late Paleozoic assembly of the Alexander-Wrangellia-Peninsular composite terrane, Canadian and Alaskan Cordillera: Geological Society of America Bulletin, v. 126, p.1531-1550.

Berg, H.C., Jones, D.L., and Richter, D.H., 1972, Gravina-Nutzotin belt-Tectonic significance of an upper Mesozoic sedimentary and volcanic sequence in southern and southeastern Alaska: U.S. Geological Survey Professional Paper 800-D, p. 1-24.

Berger, A.L., Spotila, J.A., Chapman, J.B., Pavlis, T.L., Enkelmann, D., Ruppert, N., and Buscher, J.T., 2008, Architecture, kinematics, and exhumation of a convergent orogenic wedge-A thermochronological investigation of tectonic-climatic interactions within the central St. Elias orogeny, Alaska: Earth and Planetary Science Letters, v. 270, p. 13-24.

Berman, R.G., Ryan, J.J., Gordey, S.P., and Villeneuve, M., 2007, Permian to Cretaceous polymetamorphic evolution of the Stewart River region, Yukon-Tanana terrane, Yukon, Canada-PT evolution linked with in situ SHRIMP monazite geochronology: Journal of Metamorphic Geology, v. 25, p. 803-827. 
Bird, K.J., 1977, Late Paleozoic carbonates from the south-central Brooks Range, in Blean, K.M., ed., The United States Geological Survey in Alaska; accomplishments during 1976: U.S. Geological Survey Circular 751-B, p. B19-B20.

Blodgett, R.B., 1992, Taxonomy and paleobiogeographic affinities of an Early Middle Devonian (Eifelian) gastropod faunule from the Livengood quadrangle, east-central Alaska:

Palaeontographica Abteilung A, v. 221, p. 125-168.

Blodgett, R.B., Boucot, A.J., Rohr, D.M., and Pedder, A.E.H., 2010, The Alexander terrane of Alaska--a displaced fragment of northeast Russia? Evidence from Silurian-Middle Devonian megafossils and stratigraphy: Memoirs of the Association of Australasian Palaeontologists 39, p. 323-339.

Blodgett, R.B., Clough, J.G., Harris, A.G., and Robinson, M.S., 1992, The Mount Copleston Limestone, a new Lower Devonian Formation in the Shublik Mountains, northeastern Brooks Range, Alaska, in Bradley, D.C., and Ford, A.B., eds., Geologic Studies in Alaska by the U.S. Geological Survey, 1990: U.S. Geological Survey Bulletin 1999, p. 3-7.

Blodgett, R.B., Zhang, N., Ormiston, A.R., and Weber, F.R., 1988, A late Silurian age determination for the limestone of the Lost Creek unit, Livengood C-4 quadrangle, east-central Alaska, in Hamilton, T.E., and Galloway, J.P., eds., The United States Geological Survey in Alaska-Accomplishments Circular during 1987: U.S. Geological Survey Circular 1016, p. 5456.

Blythe, A.E., Bird, J.M., and Omar, G.I., 1996, Deformational history of the central Brooks Range, Alaska-Results from fission-track and ${ }^{40} \mathrm{Ar} /{ }^{39} \mathrm{Ar}$ analyses: Tectonics, v. 15 , p. 440 455.

Blythe, A.E., Murphy, J.M., and O’Sullivan, P.B., 1997, Tertiary cooling and deformation in the south-central Brooks Range-Evidence from zircon and apatite fission-track analyses: Journal of Geology, v. 105, p. 583-599.

Boak, J.M., Turner, D.L., Henry, D.J., Moore, T.E., and Wallace, W.K., 1987, Petrology and KAr ages of the Misheguk igneous sequence-an allochthonous mafic and ultramafic complexand its metamorphic aureole, western Brooks Range, Alaska, in Tailleur, I., and Weimer, P., eds., Alaskan North Slope Geology: Pacific Section, Society of Economic Paleontologists and Mineralogists, Bakersfield, California, p. 737-746.

Box, S.E., 1985, Early Cretaceous orogenic belt in northwestern Alaska: internal organization, lateral extent and tectonic interpretation, in Howell, D.G., ed., Tectonostratigraphic Terranes of the Circum-Pacific Region, Circum-Pacific Council for Energy and Mineral Resources, Earth Science Series, v. 1, p. 137-145.

Box, S.E., 1987, Late Cretaceous or younger sw-directed extensional faulting-Cosmos Hills, Brooks Range, Alaska: Geological Society of America Abstracts with Programs, v. 19, no. 6, p. 361.

Box, S.E., and Elder, W.P., 1992, Depositional and biostratigraphic framework of the Upper Cretaceous Kuskokwim Group, southwestern Alaska, in Bradley, D.C., and Ford, A.B., eds., Geologic Studies in Alaska by the U.S. Geological Survey, 1990: U.S. Geological Survey Bulletin 1999, p. 8-16.

Box, S.E., Karl, S.M., Bradley, D.C., Miller, M.L., Ayuso, R.A., and Friedman, R.M., 2015, Tikchik terrane (SW Alaska) records Pennsylvanian-Early Permian collision of oceanic arc with continental Farewell terrane: Geological Society of America Abstracts with Programs, v. 47, no. 4, p. 8. 
Box, S.E., Karl, S.M., Jones, J., Lease, R., Bradley, D.C., Haeussler, P.J., Graham, G., Saltus, R., and Hults, C., 2013, Detrital zircon constraints on sources, age of deformation and localization of mineral deposits of Kahiltna basin, south-central Alaska: Geological Society of America Abstracts with Programs, v. 45, no. 7, p. 77.

Box, S.E., Moll-Stalcup, E.J., Frost, T.P., and Murphy, J.M., 1993, Preliminary geologic map of the Bethel and southern Russian Mission quadrangles, Alaska: U.S. Geological Survey Map MF 2226-A, scale 1:250,000, 20 p.

Box, S.E., Moll-Stalcup, E.J., Wooden, J.L., and Bradshaw, J.Y., 1990, Kilbuck terrane-Oldest known rocks in Alaska: Geology, v. 18, p. 1219-1222.

Box, S.E., and Patton, W.W., Jr., 1989, Igneous history of the Koyukuk terrane, western Alaska - Constraints on the origin, evolution, and ultimate collision of an accreted island arc terrane: Journal of Geophysical Research, v. 94, no. B11, p. 15,843-15,867.

Brabb, E.E., 1970, Preliminary geologic map of the Black River quadrangle, east-central Alaska: U.S. Geological Survey Miscellaneous Geologic Investigations Map I-601, scale 1:250,000.

Bradley, D.C., Dumoulin, J.A., Layer, P., Sunderlin, D., Roeske, S., McClelland, W., Harris, A.G., Abbott, G., Bundtzen, T., and Kusky, T., 2003a, Late Paleozoic orogeny in Alaska's Farewell terrane: Tectonophysics, v. 372, p. 23-40.

Bradley, D.C., Kusky, T.M., Haeussler, P.J., Goldfarb, R., Miller, M., Dumoulin, J., Nelson, S.W., and Karl, S., 2003b, Geologic signature of early Tertiary ridge subduction in Alaska, in Sisson, V.B., Roeske, S.M., and Pavlis, T.L., eds., Geology of a transpressional orogeny developed during ridge-trench interaction along the North Pacific margin: Boulder, Colorado, Geological Society of America Special Paper 371, p. 19-49.

Bradley, D.C., McClelland, W., Friedman, R.M., O’Sullivan, P., Layer, P., Miller, M.L., Dumoulin, J.A., Till, A.B., Abbott, J.G., Bradley, D.C., and Wooden, J.L., 2014, Proterozoic geochronological links between the Farewell, Kilbuck and Arctic Alaska terranes: Journal of Geology, v. 122, p. 237-258.

Brabb, E.E., and Churkin, M. Jr., 1969, Geologic map of the Charley River quadrangle, eastcentral Alaska: U.S. Geological Survey Miscellaneous Geologic Investigations Map I-573, 1 sheet, scale 1:250,000.

Brogan, G.E., Cluff, L.S., Korringa, M.K., and Slemmons, D.B., 1975, Active faults of Alaska: Tectonophysics, v. 29, p. 73-85.

Brosgé, W.P., and Reiser, H.N., 1964, Geologic map and section of the Chandalar quadrangle, Alaska: U.S. Geological Survey Miscellaneous Geologic Investigations Map I-375, scale $1: 250,000$.

Brosgé, W.P., and Reiser, H.H., 1969, Preliminary geologic map of the Coleen quadrangle, Alaska: U.S. Geological Survey Open-File Report 370, 1 sheet, scale 1:250,000.

Brosgé, W.P., and Reiser, H.N., 2000, Geologic map of the Christian quadrangle, Alaska: U.S. Geological Survey Open-File Report 00-192, 14p., scale 1:250,000.

Brosgé, W.P., Reiser, H.N., Dutro, J.T., Jr., and Detterman, R.L., 1976, Reconnaissance geologic map of the Table Mountain quadrangle, Alaska: U.S. Geological Survey Open File Map 76546, 2 sheets, scale 1:200,000.

Brosgé, W.P., Reiser, H.N., Dutro, J.T., Jr., and Detterman, R.L., 1979, Bedrock geologic Map of the Philip Smith Mountains quadrangle, Alaska: U.S. Geological Survey Miscellaneous Field Studies Map MF-897B, scale 1:250,000. 
Brosgé, W.P., Reiser, H.N., Dutro, J.T., Jr., Detterman, R.L., and Tailleur, I.L., 2001, Geologic map of the Arctic quadrangle, Alaska: U.S. Geological Survey Geologic Investigations Series Map I-2673, 2 sheets, scale 1:200,000.

Bruhn, R.L., and Haeussler, P.J., 2006, Deformation driven by subduction and microplate collision-Geodynamics of Cook Inlet basin, Alaska: Geological Society of America Bulletin, v. 118, p. 289-303.

Bundtzen, T.K., Harris, E.E., and Gilbert, W.G., 1997, Geologic map of the eastern half of the McGrath quadrangle, Alaska: Alaska Division of Geological \& Geophysical Surveys Report of Investigations 97-14a, 39 p., scale 1:250,000.

Campbell, R.H., 1967, Areal geology in the vicinity of the Chariot site, Lisburne Peninsula, northwest Alaska: U.S. Geological Survey Professional Paper 395, 71 p.

Chapman, J.B., Pavlis, T.L., Bruhn, R.L., Worthington, L.L., Gulick, S.P.S., and Berger, A.L., 2012, Structural relationships in the eastern syntaxis of the St. Elias orogen, Alaska:

Geosphere, v. 8, p. 105-126, doi:10.1130/GE00677.1.

Chapman, R.M., Yeend, W.E., and Patton, W.W., Jr., 1975, Preliminary reconnaissance geologic map of the western half of Kantishna River quadrangle, Alaska: U.S. Geological Survey OpenFile Map 75-351, scale 1:250,000.

Chian, D., Hackson, H.R., Hutchinson, D.R., Shimeld, J.W., Oakey, G.N., Lebedeva-Ivanova, N., Li Q., Saltus, R.W., and Mosher, D.C., 2016, Distribution of crustal types in Canada Basin, Arctic Ocean: Tectonophysics, http://dx.doi.org/10.1016/j.tecto.2016.01.038.

Christiansen, P.P., and Snee, L.W., 1994, Structure, metamorphism, and geochronology of the Cosmos Hills and Ruby Ridge, Brooks Range schist belt, Alaska: Tectonics, v. 13, p. 193-213.

Churkin, M., Jr., Foster, H.L., and Chapman, R.M., 1982, Terranes and suture zones in eastcentral Alaska: Journal of Geophysical Research, v. 87, p. 3718-3730.

Clift, P.D., Pavlis, T., DeBari, S.M., Draut, A.E., Rioux, M., and Kelemen, P.B, 2005, Subduction erosion of the Jurassic Talkeetna-Bonanza arc and the Mesozoic accretionary tectonics of western North America: Geology, v. 33, p. 881-884.

Cohen, K.M., Finney, S.C., Gibbard, P.L., and Fan, J.-X, 2013, The ICS International Chronostratigraphic Chart: Episodes, v. 36, p. 199-204.

Cole, F., Bird, K.J., Mull, C.G., Wallace, W.K., Sassi, W., Murphy, J.M., and Lee, M., 1999, A balanced cross section and kinematic and thermal model across the northeastern Brooks Range mountain front, Arctic National Wildlife Refuge, Alaska, in ANWR Assessment Team, Oil and gas resource potential of the 1002 area, Arctic National Wildlife Refuge, Alaska: U.S., Geological Survey Open-File Report 98-34, CD-ROM, p. SM 1-60.

Cole, F., Bird, K.J., Toro, J., Roure, F., O’Sullivan, P.B., Pawlewicz, M., and Howell, D.G., 1997, An integrated model for the tectonic development of the frontal Brooks Range and Colville Basin $250 \mathrm{~km}$ west of the Trans-Alaska Crustal Transect: Journal of Geophysical Research, v. 102, p. 20,685-20,708.

Cole, R.B., Layer, P.W., Hooks, B., Cyr, A., and Turner, J., 2007, Magmatism and deformation in a terrane suture zone south of the Denali fault, northern Talkeetna Mountains, Alaska, in Ridgway, K.D., Trop, J.M., Glen, J.M.G., and O’Neill, J.M., eds., Tectonic Growth of a Collisional Continental Margin-Crustal Evolution of Southern Alaska: Geological Society of America Special Paper 431, p. 477-506.

Colpron, M., 2012, Preliminary observations on the geology of the Rackla belt, Mount Ferrell map area (NTS 106C/3), central Yukon, in MacFarlane, K.E., and Sack, P.J., eds., Yukon Exploration and Geology 2011: Yukon Geological Survey, p. 27-43. 
Colpron, M., Nelson, J.L., and Murphy, D.C., 2006, A tectonostratigraphic framework for the pericratonic terranes of the northern Cordillera, in Colpron, M., and Nelson, J.L., eds., Paleozoic evolution and metallogeny of pericratonic terranes at the ancient Pacific margin of North American, Canadian and Alaskan cordillera: Geological Association of Canada Special Paper 45, p. 1-23.

Coney, P.J., and Jones, D.L., 1985, Accretion tectonics and crustal structure in Alaska:

Tectonophysics, v. 119, p. 265-283.

Crone, A.J., Personius, S.F., Craw, P.Z., Haeussler, P.J., and Staft, L.A., 2004, The Susitna Glacier thrust fault-Characteristics of surface ruptures on the fault that initiated the 2002 Denali fault earthquake: Bulletin of the Seismological Society of America, v. 94, no. 6B, p. S5-22.

Csejtey, B., Jr., Nelson, W.H., Jones, D.L., Silberling, N.J., Dean, R.M., Morris, M.S., Lanphere, M.A., Smith, J.G., and Silberman, M.L., 1978, Reconnaissance geologic map and geochronology, Talkeetna Mountains quadrangle, northern part of Anchorage quadrangle, and southwest corner of Healy quadrangle, Alaska: U.S. Geological Survey Open File Report 78558A, scale 1:250,000.

Csejtey, B., Jr., and St. Aubin, D.R., 1981, Evidence for northwestward thrusting of the Talkeetna superterrane, and its regional significance, in Albert, N.R.D., and Hudson, T., eds., The United States Geological Survey in Alaska-Accomplishments during 1970: U.S. Geological Survey Circular 823-B, p. B49-B51.

Cushing, G.W., and Foster, H.L., 1984, Structural observations in the Circle quadrangle, YukonTanana Upland, Alaska, in Coonrad, W.L., and Elliott, R.L., eds., The United States Geological Survey in Alaska-Accomplishments during 1981: U.S. Geological Survey Circular 868, p. 64-65.

Cushing, G.W., and Gardner, M.C., 1987, The structural geology and tectonics of the central Yukon-Koyukuk Basin, western Alaska: Geological Society of America Abstracts with Programs, v. 19, p. 633-634.

Curtis, S.M., Ellersieck, Inyo, Mayfield, C.F., and Tailleur, I.L., 1984, Reconnaissance geologic map of southwestern Misheguk Mountain quadrangle, Alaska: U.S. Geological Survey Miscellaneous Investigations series Map I-1502, scale 1:63,360.

Curtis, S.M., Ellersieck, Inyo, Mayfield, C.F., and Tailleur, I.L., 1990, Reconnaissance geologic map of the De Long Mountains A1 and B1 quadrangles and part of the C2 quadrangle, Alaska: U.S. Geological Survey Miscellaneous Investigations Series Map I-1930, scale 1:63,360.

Davidson, C., Hollister, L.S., and Schmid, S.M., 1992, Role of melt in the formation of a deepcrustal compressive shear zone-The Maclaren Glacier metamorphic belt, south central Alaska: Tectonics, v. 11, p. 348-359.

Davidson, C., and McPhillips, D., 2007, Along strike variations in metamorphism and deformation of the strata of the Kahiltna basin, south-central Alaska, in Ridgway, K.D., Trop, J.M., Glen, J.M.G., and O’Neill, J.M., eds., Tectonic Growth of a Collisional Continental Margin-Crustal Evolution of Southern Alaska: Geological Society of America Special Paper 431, p. 439-454, doi:10.1130/2007.2431(17).

Day, E.M., Pavlis, T.L., and Amato, J.M., 2011, Diverging histories of the Liberty Creek and Iceberg Lake blueschist bodies, south central Alaska [abstract T51F-2426]: Proceedings, American Geophysical Union 2011 Fall Meeting, San Francisco California, 5-9 December.

Day, W.C., Aleinikoff, J.N., and Gamble, B. 2002, Geochemistry and age constraints on metamorphism and deformation in the Fortymile River area, eastern Yukon-Tanana Upland, 
Alaska, in Wilson, F.H., and Galloway, J.P., eds., Studies by the United States Geological Survey in Alaska, 2000: U.S. Geological Survey Professional Paper 1662, p. 5-18.

De Vera, J., McClay, K.R., and King, A.R., 2004, Structure of the Red Dog District, western Brooks Range, Alaska: Economic Geology, v. 99, p. 1415-1434.

Decker, J., Bergman, S.C., Blodgett, R.B., Box, S.E., Bundtzen, T.K., Clough, J.G., Coonrad, W.L., Gilbert, W.G., Miller, M.L., Murphy, J.M., Robinson, M.S., and Wallace, W.K., 1994, Geology of southwestern Alaska, in Plafker, G., and Berg, H.C., eds., The Geology of Alaska: Boulder, Colorado, Geological Society of America, The Geology of North America, v. G-1, p. 285-310.

Detterman, R.L., Bickel, R.S., and Gryc, G., 1963, Geology of the Chandler River Region, Alaska: U.S. Geological Survey Professional Paper 303-E, 324 p., 1 sheet, scale 1:125,000.

Detterman, R.L., Case, J.E., Miller, J.W., Wilson, F.H., and Yount, M.E., 1996, Stratigraphic framework of the Alaska Peninsula: U.S. Geological Survey Bulletin 1969-A, 74 p.

Detterman, R.L., and Hartsock, J.K., 1966, Geology of the Iniskin-Tuxedni Region, Alaska: U.S. Geological Survey Professional Paper 512, 78 p.

Dillon, J.T., Brosgé, W.P., and Dutro, J.T., Jr., 1986, Generalized geologic map of the Wiseman quadrangle, Alaska: U.S. Geological Survey Open-File Report 86-219, scale 1:250,000.

Dover, J.H., 1992, Geologic map and fold- and thrust-belt interpretation of the southeastern part of the Charley River quadrangle, east-central Alaska: U.S. Geological Survey Miscellaneous Investigations Series Map I-1942, 2 sheets, scale 1:100,000.

Dover, J.H., 1994, Geology of part of east-central Alaska, in Plafker, G., and Berg, H.C., eds., The Geology of Alaska: Boulder, Colorado, Geological Society of America, The Geology of North America, v. G-1, p. 153-204.

Dover, J.H., and Miyaoka, R.T., 1988, Reinterpreted geologic map and fossil data, Charley River quadrangle, east-central Alaska: U.S. Geological Survey Miscellaneous Field Studies Map MF-2004, 2 sheets, scale 1:250,000.

Dover, J.H., Tailleur, I.L., and Dumoulin, J.A., 2004, Geologic and fossil locality maps of the west-central part of the Howard Pass quadrangle and part of the adjacent Misheguk Mountain quadrangle, western Brooks Range, Alaska: U.S. Geological Survey Miscellaneous Field Studies Map MF-2413, 2 sheets, scale 1:250,000.

Dumitru, T.A., Miller, E.J., O’Sullivan, P.B., Amato, J.M., Hannula, K.A., Calvert, A.T., and Gans, P.B., 1995, Cretaceous to Recent extension in the Bering Strait region, Alaska:

Tectonics, v. 14, p. 549-563.

Dumoulin, J.A., 2001, Lithologies of the basement complex (Devonian and older) in the National Petroleum Reserve-Alaska, in Houseknecht, D.W., ed., NPRA Core Workshop; Petroleum Plays and Systems in the National Petroleum Reserve-Alaska: SEPM Core Workshop, no. 21, p. 201-214.

Dumoulin, J.A., Harris, A.G., Gagiev, M., Bradley, D.C., and Repetski, J.E., 2002, Lithostratigraphic, conodont, and other faunal links between lower Paleozoic strata in northern and central Alaska and northeastern Russia, in Miller, E.L., Grantz, A., and Klemperer, S.L., eds., Tectonic Evolution of the Bering Shelf-Chukchi Sea-Arctic Margin and Adjacent Landmasses: Boulder, Colorado, Geological Society of America Special Paper 360, p. 291-312.

Duncan, A., Hanks, C., Wallace, W.K., O’Sullivan, P.B., and Parris, T.M., 2012, An integrated model of the structural evolution of the central Brooks Range foothills, Alaska, using structural 
geometry, fracture distribution, geochronology, and microthermometry: American Association of Petroleum Geologists Bulletin, v. 96, p. 2245-2274.

Dusel-Bacon, C., 1994a, Metamorphic history of Alaska, in Plafker, George, and Berg, H.C., eds., The Geology of Alaska: Boulder, Colorado, Geological Society of America, The Geology of North America, v. G-1, p. 495-533.

Dusel-Bacon, C., 1994b, Map and table showing metamorphic rocks of Alaska, in Plafker, George, and Berg, H.C., eds., The Geology of Alaska: Boulder, Colorado, Geological Society of America, The Geology of North America, v. G-1, plate 4, scale 1:2,500,000, 2 sheets.

Dusel-Bacon, C., Aleinikoff, J.N., Day, W.C., and Mortensen, J.K., 2015, Mesozoic magmatism and timing of epigenetic $\mathrm{Pb}-\mathrm{Zn}$-Ag mineralization in the western Fortymile mining district, east-central Alaska-Zircon U-Pb geochronology, whole-rock geochemistry, and $\mathrm{Pb}$ isotopes: Geosphere, v. 11, p. 786-822, doi:10.1130/GES0192.1

Dusel-Bacon, C., Day, W.C., and Aleinikoff, J.N., 2013, Geochemistry, petrography, and zircon U-Pb geochronology of Paleozoic metaigneous rocks in the Mount Veta area of east-central Alaska-Implications for the evolution of the westernmost part of the Yukon-Tanana terrane: Canadian Journal of Earth Sciences, v. 50, p. 826-846.

Dusel-Bacon, C., Hansen, V.L., and Scala, J.A., 1995, High-pressure amphibolite facies dynamic metamorphism and the Mesozoic tectonic evolution of an ancient continental margin, eastcentral Alaska: Journal of Metamorphic Geology, v. 13, p. 9-24.

Dusel-Bacon, C., Hopkins, M.J., Mortensen, J.K., Dashevsky, S.S., Bressler, J.R., and Day, W.C., 2006, Paleozoic tectonic and metallogenic evolution of the pericratonic rocks of eastcentral Alaska and adjacent Yukon Territory, in Colpron, M., and Nelson, JL, eds., Paleozoic Evolution and Metallogeny of Pericratonic Terranes at the Ancient Pacific Margin of North America, Canadian and Alaskan Cordillera: Geological Association of Canada Special Paper 45, p. 25-74.

Dusel-Bacon, C., Lanphere, M.A., Sharp, W.D., Layer, P.W., and Hanson, V.L., 2002, Mesozoic thermal history and timing of structural events for the Yukon-Tanana Upland, east-central Alaska $-{ }^{40} \mathrm{Ar} /{ }^{39} \mathrm{Ar}$ data from metamorphic and plutonic rocks: Canadian Journal of Earth Sciences, v. 39, p. 1013-1051.

Dusel-Bacon, C., and Murphy, J.M., 2001, Apatite fission-track evidence of wide-spread Eocene heating and exhumation in the Yukon-Tanana Upland, interior Alaska: Canadian Journal of Earth Sciences, v. 38, p. 1191-1204.

Dusel-Bacon, C., and Williams, I.S., 2009, Evidence for prolonged mid-Paleozoic plutonism and ages of crustal sources in east-central Alaska from SHRIMP U-Pb dating of syn-magmatic, inherited, and detrital zircon: Canadian Journal of Earth Sciences, v. 46, p. 21-39.

Dusel-Bacon, C., Wooden, J.L., and Layer, P.W., 2003, A Cretaceous SHRIMP U-Pb zircon age for the West Point orthogneiss-Evidence for another gneiss dome in the Yukon-Tanana Upland, in Galloway, J.P., ed., Studies in Alaska by the U.S. Geological Survey during 2001: U.S. Geological Survey Professional Paper 1678, p. 41-60.

Dutro, J.T., Jr., Brosgé, W.P., Lanphere, M.A., and Reiser, H.N., 1976, Geologic significance of Doonerak structural high, central Brooks Range, Alaska: American Association of Petroleum Geologists Bulletin, v. 60, p. 952-961.

Eberhart-Phillips, D., Christensen, D.H., Brocher, T.M., Hansen, R., Ruppert, N.A., Haeussler, P.J., and Abers, G.A., 2006, Imaging the transition from Aleutian subduction to Yakutat collision in central Alaska, with local earthquakes and active source data: Journal of Geophysical Research, v. 111, 31 p., doi:10.1029/2005JB004240. 
Ellersieck, I., Curtis, S.M., Mayfield, C.F., and Tailleur, I.L., 1984, Reconnaissance geologic map of south-central Misheguk Mountain quadrangle: U.S. Geological Survey Miscellaneous Investigations Series Map I-1504, scale 1:63,360.

Ellersieck, I., Curtis, S.M., Mayfield, C.F., and Tailleur, I.L.,1990, Reconnaissance geologic map of the De Long Mountains A2 and B2 quadrangles and part of the C2 quadrangle, Alaska: U.S. Geological Survey Miscellaneous Investigations Series Map I-1931, scale 1:63,360.

Embry, A.F., 1990, Geological and geophysical evidence in support of the hypothesis of anticlockwise rotation of northern Alaska: Marine Geology, p. 93, p. 317-329.

Estabrook, C.H., Nåbělek, J.L., and Lerner-Lam, A.L., 1992, Tectonic model of the PacificNorth American plate boundary in the Gulf of Alaska from broadband analysis of the 1979 St. Elias, Alaska, earthquake and its aftershocks: Journal of Geophysical Research, v. 97, p. 65876612.

Ferris, A., Abers, G.A., Christensen, D.H., and Veenstra, E., 2003, High resolution image of the subducted Pacific plate beneath central Alaska, 50-150 km depth: Earth and Planetary Science Letters, v. 214, p. 575-588.

Finzel, E.S., Trop, J.M., Ridgway, K.D., and Enkelmann, E., 2011, Upper plate proxies for flatslab subduction processes in southern Alaska: Earth and Planetary Science Letters, v. 303, p. 348-360.

Fitzgerald, P.G., Sorkhabi, R.B., Redfield, T.F., and Stump, E., 1995, Uplift and denudation of the central Alaska Range-A case study in the use of apatite fission track thermochronology to determine absolute uplift parameters: Journal Geophysical Research, v. 100, p. 20,175-20,191.

Forbes, R.B., and Lanphere, M.A., 1973, Tectonic significance of mineral ages of blueschists near Seldovia, Alaska: Journal of Geophysical Research, v. 78, p. 1383-1386.

Foster, H.L., 1970, Reconnaissance geologic map of the Tanacross Quadrangle, Alaska: U.S. Geological Survey Miscellaneous Geologic Investigations Map 593, 1 sheet, scale 1:250,000.

Foster, H.L., and Cushing, G.W., 1985, Tertiary (?) folding in the Tanacross quadrangle, in Bartsch-Winkler, S., and Reed, K.M., eds., The United States Geological Survey in Alaska: Accomplishments during 1983: U.S. Geological Survey Circular 945, p. 38-40.

Foster, H.L., Laird, J., Keith, T.E.C., Cushing, G.W., and Menzie, W.D., 1983 Preliminary Geologic Map of the Circle Quadrangle, Alaska: U.S. Geological Survey Open-File Report 83170A, scale 1:250,000.

Freeman, L.K., Griesel, G.A., Newberry, R.J, Elliot, B.A., Szumigala, D.J., Lough, T.A., and Werdon, M., 2014, Revisiting the Ruby terrane-Insights from geologic mapping in the Moran area, central-interior Alaska [abs.]: Newsletter of the Alaska Geological Society, v. 45, no. 2, p. 1-2. http://www.alaskageology.org/documents/14/October2014Newsletter.pdf.

Fuis, G.S., Levander, Alan, Lutter, W.J., Wissinger, E.S., Moore T.E., and Christensen, N.I., 1995, Seismic images of the Brooks Range, Arctic Alaska reveal crustal-scale duplexing: Geology, v. 23, no. 1, p. 65-68.

Fuis, G.S., Moore, T.E., Plafker, G., Brocher, T.M., Fisher, M.A., Mooney, W.D., Nokleberg, W.J., Page, R.A., Beaudoin, B.C., Christensen, N.I., Levander, A.R., Lutter, W.J., Saltus, R.W., and Ruppert, N.A., 2008, Trans-Alaska Crustal Transect and continental evolution involving subduction underplating and synchronous foreland thrust: Geology, p. 36, p. 267270.

Gabrielse, H., Murphy, D.C., and Mortensen, J.K., 2006, Cretaceous and Cenozoic dextral orogeny-parallel displacements, magmatism, paleogeography, north-central Canadian Cordillera, in Haggart, J.W., Enkin, R.J., and Monger, J.W.H., eds., Paleogeography of the 
North American Cordillera-Evidence For and Against Large-Scale Displacements:

Geological Association of Canada Special Paper 46, p. 255-276.

Gamble, B.M., Reed, B.L., Richter, D.H., and Lanphere, M.A., 2013, Geologic map of the east half of the Lime Hills 1:250,000-scale quadrangle: U.S. Geological Survey Open File Report 2013-1090, scale 1:250,000.

Gardner, M.C., Bergman, S.C., Cushing, G.W., MacKevett, E.M., Plafker, G., Campbell, R.B., Dodds, C.J., McClelland, W.C., and Mueller, P.A., 1988, Pennsylvanian pluton stitching of Wrangellia and the Alexander terrane, Wrangell Mountains, Alaska: Geology, v. 16, p. 967971.

Gardner, M.C., MacKevett, E.M., and McClelland, W.D., 1986, The Chitina fault system of southern Alaska-An Early Cretaceous collisional suture zone: Geological Society of America Abstracts with Programs, v. 18, p.108.

Gasser, D., Bruand, E., Stüwe, K., Foster, D.A., Schuster, R., Fügenschuh, B., and Pavlis, T., 2011, Formation of a metamorphic complex along an obliquely convergent margin-Structural and thermochronological evolution of the Chugach Metamorphic Complex, southern Alaska: Tectonics, v. 30, 25 p., TC2012, doi:10.1029/2010TC002776.

Gehrels, G.E., Butler, R.F., and Bazard, D.R., 1996, Detrital zircon geochronology of the Alexander terrane, southeastern Alaska: Geological Society of America Bulletin, v. 108, p. 722-734.

Ghent, E.D., Roeske, S.M., Stout, M.Z., Bradshaw, J.Y., and Snee, L.W., 2001, Mesozoic granulite facies metamorphism of the Pitka mafic-ultramafic complex, Northern Alaska [abs.]: Geological Society of America Abstracts with Programs, v. 33, no. 6, p. 249-250.

Gillis, R.J., Decker, P.L., Wartes, M.A., Loveland, A.M., and Hubbard, T.D., 2014, Geologic map of the south-central Sagavanirktok quadrangle, North Slope, Alaska: Alaska Division of Geological and Geophysical Surveys Report of Investigations 2014-4, 24 p., 2 sheets, scale $1: 63,360$.

Gilman, T., Feineman, M., and Fisher, D., 2009, The Chulitna terrane of south-central AlaskaA rifted volcanic arc caught between the Wrangellia composite terrane and the Mesozoic margin of North America: Geological Society of America Bulletin, v. 121, p. 979-991.

Glen, J.M.G., Schmidt, J., and Morin, R., 2007, Gravity and magnetic character of south-central Alaska-Constraints on geologic and tectonic interpretations, and implications for mineral exploration, in Ridgeway, K.D., Trop, J.M., Glen, J.M.G., and O’Neill, J.M., eds., Tectonic growth of a collisional continental margin-Crustal evolution of southern Alaska: Geological Society of America Special Paper 431, p. 593-622.

Gordey, S.P., and Makepeace, A.J., 2001, Bedrock Geology, Yukon Territory: Geological Survey of Canada Open File 3754; 2 sheets, scale 1:1,000,000.

Gottlieb, E.S., Meisling, K.E., Miller, E.L., and Mull, C.G., 2014, Closing the Canada BasinDetrital zircon geochronology relationships between the North Slope of Arctic Alaska and the Franklinian mobile belt of Arctic Canada: Geosphere, v. 10, p. 1366-1384.

Gottschalk, R.R., 1990, Structural evolution of the schist belt, south-central Brooks Range fold and thrust belt, Alaska: Journal of Structural Geology, v. 12, p. 453-469.

Gottschalk, R.R., and Oldow, J.S., 1988, Low-angle normal faults in the south-central Brooks Range fold and thrust belt, Alaska: Geology, v. 16, p. 395-399.

Gottschalk, R.R., and Snee, L.W., 1998, Tectonothermal evolution of metamorphic rocks in the south-central Brooks Range, Alaska-Constraints from ${ }^{40} \mathrm{Ar} /{ }^{39} \mathrm{Ar}$ geochronology, in Oldow, 
J.S., and Avé Lallemant, H.G., eds., Architecture of the Central Brooks Range Fold and Thrust Belt, Arctic Alaska: Geological Society of America Special Paper 324, p. 225-251.

Grantz, A., 1960, Geologic map of Talkeetna Mountains (A-2) quadrangle, Alaska and the contiguous area to the north and northwest: U.S. Geological Survey Miscellaneous Geologic Investigations Map I-313, 1 sheet, scale 1:48,000.

Grantz, A., 1966, Strike-slip faults in Alaska: U.S. Geological Survey Open-File Report, 82 p.

Grantz, A., Dinter, D.A., and Culotta, R.C., 1987, Structure of the continental shelf north of the Arctic National Wildlife Refuge, in Bird, K.J., and Magoon, L.B., eds., Petroleum Geology of the northern part of the Arctic National Wildlife Refuge, northeastern Alaska, U.S. Geological Survey Bulletin 1778, p. 271-276.

Grantz, A., Eittreim, S.L., and Dinter, D.A., 1979, Geology and tectonic development of the continental margin north of Alaska, in Keen, C.E., ed., Crustal properties across passive margins: Tectonophysics, v. 59, p. 263-291.

Grantz, A., and May, S.D., 1983, Rifting history and structural development of the continental margin north of Alaska, in Watkins, J.S., and Drake, C.L., eds., Studies in continental margin geology: American Association of Petroleum Geologists Memoir 34, p. 77-100.

Hacker, B.R., Kelemen, P.B., Rioux, M., McWilliams, M.O., Gans, P.B., Reiners, P.W., Layer, P.W., Soderlund, U., and Vervoort, J.D., 2011, Thermochronology of the Talkeetna intraoceanic arc of Alaska-Ar/Ar, U- Th/He, Sm- Nd, and Lu- Hf dating: Tectonics, v. 30, p. 1-23.

Haeussler, P.J., 2008, An overview of the Neotectonics of Interior Alaska-Far-field deformation from the Yakutat microplate collision, in Freymueller, J.T., Haeussler, P.J., Wesson, R., and Ekstrom, G., eds., Active Tectonics and Seismic Potential of Alaska: Geophysical Monograph Series 179, American Geophysical Union, Washington D.C., p. 83108; doi:10.1029/179GM05.

Haeussler, P.J., Armstrong, P.A., Liberty, Lee, M., Ferguson, K., Finn, S.P., Arkle, J.C., and Pratt, T.L., 2015, Focused exhumation along megathrust splay faults in Prince William Sound, Alaska: Quaternary Science Reviews, v. 113, p. 8-22.

Haeussler, P.J., Bradley, D.C., and Goldfarb, R.J., 2003, Brittle deformation along the Gulf of Alaska margin in response to Paleocene-Eocene triple junction migration, in Sisson, V.B., Roeske, S.M., and Pavlis, T.L., eds., Geology of a transpressional orogeny developed during ridge-trench interaction along the North Pacific margin: Boulder, Colorado, Geological Society of America Special Paper 371, p. 119-140.

Haeussler, P.J., Bruhn, R.L., and Pratt, T.L., 2000, Potential seismic hazards and tectonics of the upper Cook Inlet basin, Alaska, based on analysis of Pliocene and younger deformation:

Geological Society of America Bulletin, v. 112, p. 1414-1429.

Haeussler, P.J., O’Sullivan, P., Berger, A.L., and Spotila, J.A., 2008, Neogene exhumation of the Tordrillo Mountains, Alaska, and correlations with Denali (Mt. McKinley) in Freymueller, J.T., Haeussler, P.J., Wesson, R., and Ekstrom, G., eds., Active Tectonics and Seismic Potential of Alaska: Geophysical Monograph Series 179, American Geophysical Union, Washington D.C., p. 269-285; doi:10.1029/179GM05.

Haeussler, P.J., and Saltus, R.W., 2011, Location and extent of Tertiary structures in Cook Inlet Basin, Alaska, and mantle dynamics that focus deformation and subsidence, in Dumoulin, J.A., and Galloway, J.P., eds., Studies by the U.S. Geological Survey in Alaska, 2008-2009: U.S. Geological Survey Professional Paper 1776-D, p. 1-26. 
Hampton, B.A., Ridgway, K.D., O’Neill, J.M., Gehrels, G.E., Schmidt, J., and Blodgett, R.B., 2007, Pre-, syn-, and post-collisional stratigraphic framework and provenance of Upper Triassic-Upper Cretaceous strata in the northwestern Talkeetna Mountains, Alaska, in Ridgeway, K.D., Trop, J.M., Glen, J.M.G., and O’Neill, J.M.,, eds., Tectonic Growth of a Collisional Continental Margin-Crustal Evolution of Southern Alaska: Geological Society of America Special Paper 431, p. 401-438.

Hanks, C.L., 1993, The Cenozoic structural evolution of a fold-and-thrust belt, northeastern Brooks Range, Alaska: Geological Society of America Bulletin, v. 105, p. 287-305.

Hanks, C.L., and Wallace, W.K., 1990, Cenozoic thrust emplacement of a Devonian batholith, northeastern Brooks Range: Involvement of crystalline rocks in a foreland fold-and-thrust belt: Geology, v. 18, p 395-398.

Hannula, K.A., and McWilliams, M.O., 1995, Reconsideration of the age of blueschist facies metamorphism on the Seward Peninsula, Alaska, based on phengite ${ }^{40} \mathrm{Ar} /{ }^{39} \mathrm{Ar}$ results, in Patrick, B.E., and Day, H.W., eds., Special issue on Cordilleran high-pressure metamorphic terranes: Journal of Metamorphic Geology, v. 13, p. 125-139.

Hannula, K.A., Miller, E.L., Dumitru, T.A., Lee, J., and Rubin, C.M., 1995, Structural and metamorphic relations in the southwest Seward Peninsula, Alaska-Crustal extension and the unroofing of blueschists: Geological Society of America Bulletin, v. 107, p. 536-553.

Hansen, V.L, 1990, Yukon-Tanana terrane-A partial acquittal: Geology, v. 18, p. 365-369. Hansen, V.L., and Dusel-Bacon, C., 1998, Structural and kinematic evolution of the Yukon-

Tanana Upland tectonites, east-central Alaska-A record of late Paleozoic to Mesozoic crustal assembly: Geological Society of America Bulletin, v. 110, p. 211-230.

Harris, R., 1998, Origin and tectonic evolution of the metamorphic sole beneath the Brooks Range ophiolite, Alaska, in Oldow, J.S., and Avé Lallemant, H.G., eds., Architecture of the Central Brooks Range Fold and Thrust Belt, Arctic Alaska: Geological Society of America Special Paper 324, p. 293-312.

Harris, R., 2004, Tectonic evolution of the Brooks Range ophiolite, northern Alaska: Tectonophysics, v. 392, p. 143-163.

Harrison, J.C., St-Onge, M.R, Petrov, O.V., Strelnikov, S.I., Lopatin, B.G., Wilson, F.H., Tella, S., Paul, D., Lynds, T., Shokalsky, S.P., Hults, C.K., Bergman, S., Jepsen, H.F., and Solli, A., 2011, Geological map of the Arctic: Geological Survey of Canada, “A” Series Map 2159A, 9 sheets, doi:10.4095/287868.

Helwig, J., Kumar, N., Emmet, P., and Dinkelman, M.G., 2011, Regional seismic interpretation of crustal framework, Canadian Arctic passive margin, Beaufort Sea, with comments on petroleum potential, in Spencer, A.M., Embry, A.F., Gautier, D.L., Stoupakova, A.V., and Sørensen, K., eds., Arctic Petroleum Geology: Geological Society of London Memoir 35, p. 527-543.

Hitzman, M.W., Proffett, J.M., Jr., Schmidt, J.M., and Smith, T.E., 1986, Geology and mineralization of the Ambler district, northwestern Alaska: Economic Geology, v. 81, p. 1592-1618.

Hitzman, M.W., Smith, T.E., and Proffett, J.M., Jr., 1982, Bedrock geology of the Ambler district, southwestern Brooks Range, Alaska, Alaska Division of Geological and Geophysical Surveys Geologic Report 75, scale 1:125,000, 2 sheets.

Hoare, J.M., and Coonrad, W.L., 1978, Geologic map of the Goodnews and Hagemeister Island quadrangles region, southwestern Alaska: U.S. Geological Survey Open-File Report 78-9-B. scale 1:250,000. 
Houseknecht, D.W., Bird, K.J., and Garrity, C.P., 2012, Assessment of undiscovered petroleum resources of the Amerasia basin petroleum province: U.S. Geological Survey Scientific Investigations Report 2012-5146, 36 p.

Hults, C.P., Wilson, F.H., Donelick, R.A., and O’Sullivan, P.B., 2013, Two flysch belts having distinctly different provenance suggest no stratigraphic link between the Wrangellia composite terrane and the paleo-Alaskan margin: Lithosphere, v. 5, p. 575-594.

Johnsson, M.J., 2000, Tectonic assembly of east-central Alaska-Evidence from CretaceousTertiary sandstones of the Kandik River terrane: Geological Society of America Bulletin, v. 112, p. 1023-1042.

Johnston, S.T., 2001, The Great Alaskan Terrane Wreck-Reconciliation of paleomagnetic and geological data in the northern Cordillera: Earth and Planetary Science Letters, v. 193, p. 259272.

Julian, F.E., and Oldow, J.S., 1998, Structure and lithology of the lower Paleozoic Apoon assemblage, eastern Doonerak window, central Brooks Range, Alaska, in Oldow, J.S., and Avé Lallemant, H.G., eds., Architecture of the Central Brooks Range Fold and Thrust Belt, Arctic Alaska: Geological Society of America Special Paper 324, p. 65-80.

Kalbas, J.L., Ridgway, K.D., Miller, M.L., and Bradley, D.C., 2007, Multi-stage Cretaceous basin development in southwestern Alaska-Marine depositional responses to syn- to early post-collision (?) margin evolution: Geological Society of America Abstracts with Programs, v. 39, no. 6, p. 489.

Kalbas, J.L., Ridgway, K.D., Miller, M.L., and Bradley, D.C., 2015, Depositional systems and provenance of the Kuskokwim Group-Insights into the paleogeography of the Late Cretaceous foreland basin system of southwestern Alaska: Geological Society of America Abstracts with Programs, v. 47, no. 4, p. 9.

Karl, S.M., Aleinikoff, J.N., Dickey, C.F, and Dillon, J.T., 1989, Age and chemical composition of Proterozoic intrusive rocks at Mount Angayukaqsraq, western Brooks Range, Alaska, in Dover, J.H., and Galloway, J.P., eds., Geologic Studies in Alaska by the U.S. Geological Survey, 1988: U.S. Geological Survey Bulletin 1903, p. 10-19.

Karl, S.M., Dumoulin, J.A., Ellersieck, Inyo, Harris, A.G., and Schmidt, J.M., 1989, Preliminary geologic map of the Baird Mountains quadrangle, Alaska: U.S. Geological Survey Open-File Report 89-551, 65 p., scale 1:250,000, 1 sheet.

Kelley, J.S., 1988, Preliminary geologic map of the Chandler Lake quadrangle, Alaska: U.S. Geological Survey Open File Report 88-42, scale 1:125,000, 2 sheets.

Kusky, T.M., Bradley, D.C., and Haeussler, P.J., 1997a, Progressive deformation of the Chugach accretionary complex, Alaska, during a Paleogene ridge-trench encounter: Journal of Structural Geology, v. 19, p. 139-157.

Kusky, T.M., Bradley, D.C., Haeussler, P.J., and Karl, S.M., 1997b, Controls on accretion of flysch and mélange belts at convergent margins_-Evidence from the Chugach Bay thrust and Iceworm mélange, Chugach accretionary wedge, Alaska: Tectonics, v. 16, p. 855-878.

Labrado, A., Pavlis, T.L., Amato, J.M. and Day, E.M., 2015, The tectonic significance of the Early Cretaceous forearc-metamorphic assemblage in south-central Alaska based on detrital zircon U-Pb dating of sedimentary protoliths: Canadian Journal of Earth Sciences, v. 52, p. 1182-1190.

Lagoe, M.B., Eyles, C.H., Eyles, N., and Hale, C., 1993, Timing of late Cenozoic tidewater glaciation in the far north Pacific: Geological Society of America Bulletin, v. 105, p. 15421560. 
Lahr, J.C., and Plafker, G., 1980, Holocene Pacific-North American plate interaction in southern Alaska-Implications for the Yakataga seismic gap: Geology, v. 8, p. 483-486.

Lampe, C., Bird, K.J., Moore, T.E., Ratliff, R.A., and Freeman, B., 2012, Modeling-Integrating structural modeling, fault property analysis, and petroleum systems modeling-An example from the Brooks Range Foothills of the Alaska North Slope, in Peters, K.E., Curry, D.J., and Kacewicz, M., eds., Basin Modeling-New Horizons in Research and Applications: American Association of Petroleum Geologists Hedberg Series, no. 4, p. 119-136.

Lane, L.S., 1998, Latest Cretaceous-Tertiary tectonic evolution of northern Yukon and adjacent Arctic Alaska: American Association of Petroleum Geologists Bulletin, v. 82, p. 1353-1371.

Lane, L.S., 2007, Devonian-Carboniferous paleogeography and orogenesis, northern Yukon and adjacent Arctic Alaska: Canadian Journal of Earth Sciences, v. 44, p. 679-694.

Lane, L.S., Gehrels, G.E., and Layer, P.W., 2016, Provenance and paleogeography of the Neruokpuk Formation, northwest Laurentia-An integrated synthesis: Geological Society of America Bulletin, v. 128, p. 239-257.

Lane, L.S., Kelley, J.S., and Wrucke, C.T., 1995, Stratigraphy and structure of the Clarence River area, Yukon-Alaska north slope-A USGS-GSC co-operative project: Geological Survey of Canada, Current Research 1995-E, p. 1-9.

Law, R.D., Miller, E.L., Little, T. A., and Lee, J., 1994, Extensional origin of ductile fabrics in the schist belt, central Brooks Range, Alaska-II. Microstructural and petrofabric evidence: Journal of Structural Geology, v. 16, p. 919-940.

Layer, P.W., and Newberry, R.J., 2005, A long-term effort to determine ${ }^{40} \mathrm{Ar} /{ }^{39} \mathrm{Ar}$ ages of Alaskan mineral deposits: Report to the U.S. Geological Survey Mineral Resources External Research Program, grant 04HQGR0163, Final report, 64 p.

Lease, R.O., Haeussler, P.J., and O’Sullivan, P., 2016, Changing exhumation patterns during Cenozoic growth and glaciation of the Alaska Range-Insight from detrital geo- and thermochronology: Tectonics, 35, p. 934-955 doi:10.1002/2015TC004067.

Lesh, M.E., and Ridgway, K.D., 2007, Geomorphic evidence of active transpressional deformation in the Tanana foreland basin, south-central Alaska, in Ridgway, K.D., Trop, J.M., Glen, J.M.G., and O’Neill, J.M., eds., Tectonic Growth of a Collisional Continental MarginCrustal Evolution of Southern Alaska: Geological Society of America Special Paper 431, p. 573-592.

Little, T.A., 1992, Development of wrench folds along the Border Ranges fault system, southern Alaska, U.S.A.: Journal of Structural Geology, v. 14, p. 343-359.

Little, T.A., Miller, E.L., and Lee, J., 1994, Extensional origin of ductile fabrics in the Schist Belt, central Brooks Range, Alaska-geologic and structural studies: Journal of Structural Geology, v. 16, p. 899-918.

Loney, R.A., and Himmelberg, G.R., 1989, The Kanuti Ophiolite, Alaska: Journal of Geophysical Research, v. 94, no. B11, p. 15,869-15,900.

Lowey, G.W., 1998, A new estimate of the amount of displacement on the Denali Fault system based on the occurrence of carbonate megaboulders in the Dezadeash Formation (JuraCretaceous), Yukon, and the Nutzotin Mountains sequence (Jura-Cretaceous), Alaska: Bulletin of Canadian Petroleum Geology, v. 46, p. 379-386.

Macdonald, F.A., McClelland, W.C., Schrag, D.P., and Macdonald, W.P., 2009, Neoproterozoic glaciation on a carbonate platform margin in Arctic Alaska and the origin of the North Slope subterrane: Geological Society of America Bulletin, v. 121, p. 448-473. 
MacKevett, E.M., 1978, Geologic map of the McCarthy quadrangle, Alaska: U.S. Geological Survey Miscellaneous Investigations Map I-1032, scale 1:250,000.

Mair, J.L., Hart, C.J.R., and Stephens, J.R., 2006, Deformation history of the northwestern Selwyn Basin, Yukon, Canada-Implications for orogeny evolution and mid-Cretaceous magmatism: Geological Society of America Bulletin, v. 118, p. 304-323.

Manuszak, J.D., Ridgway, K.D., Trop, J.M., and Gehrels, G.E., 2007, Sedimentary record of the tectonic growth of a collisional continental margin-Upper Jurassic-Lower Cretaceous Nutzotin Mountains sequence, eastern Alaska Range, Alaska, in Ridgway, K.D., Trop, J.M., Glen, J.M.G., and O’Neill, J.M., eds., Tectonic Growth of a Collisional Continental MarginCrustal Evolution of Southern Alaska: Geological Society of America Special Paper 431, p. 345-377.

Mayfield, C.F., Curtis, S.M., Ellersieck, I., and Taillieur, I.L., 1984, Reconnaissance geologic map of southeastern Misheguk Mountain quadrangle, Alaska: U.S. Geological Survey Miscellaneous Investigation Series Map I-1503, scale, 1:63,360, 2 sheets.

Mayfield, C.F., Curtis, S.M., Ellersieck, I., and Taillieur, I.L., 1990, Reconnaissance geologic map of the De Long Mountains A3 and B3 quadrangles and parts of the A4 and B4 quadrangles: U.S. Geological Survey Miscellaneous Investigations Series Map I-1929, scale 1:63,360.

Mayfield, C.F., Ellersieck, I., and Tailleur, I.L., 1987, Reconnaissance geologic map of the Noatak C5, D5, D6, and D7 quadrangles, Alaska: U.S. Geological Survey Miscellaneous Investigation Series Map I-1814, scale 1:63,360, 1 sheet.

Mayfield, C.F., and Tailleur, I.L., 1978, Bedrock geology map of the Ambler River quadrangle, Alaska: U.S. Geological Survey Open-File Map 78-120A, scale 1:250,000, 1 sheet.

Mayfield, C.F., Tailleur, I.L., and Ellersieck, I., 1988a, Stratigraphy, structure, and palinspastic synthesis of the western Brooks Range, northwestern Alaska, chap. 7 in Gryc, G., ed., Geology and exploration of the National Petroleum Reserve in Alaska, 1974 to 1982: U.S. Geological Survey Professional Paper 1399, p. 143-186.

Mayfield, C.F., Tailleur, I.L., and Kirschner, C.E., 1988b, Bedrock geologic map of the National Petroleum Reserve in Alaska, in Gryc, G., ed., Geology and exploration of the National Petroleum Reserve in Alaska, 1974 to 1982: U.S. Geological Survey Professional Paper 1399, p. 187-190.

Malkowski, M.A., and Hampton, B.A., 2014, Sedimentology, U-Pb detrital geochronology, and Hf isotopic analyses from Mississippian-Permian stratigraphy of the Mystic subterrane, Farewell terrane, Alaska: Lithosphere, v. 6, p. 383-398.

Mazzotti, S., and Hyndman, R.D., 2002, Yakutat collision and strain transfer across the northern Canadian Cordillera: Geology, v. 30, p. 495-498.

Meigs, A.J., and Imm, T.A., 1995, Geometry and deformation of a duplex and its roof layerObservations from the Echooka anticlinorium, northeastern Brooks Range, Alaska, in Combellick, R.A., and Tannian, F., eds., Short notes on Alaska Geology 1995: Alaska Division of Geological and Geophysical Surveys Professional Report 117C, p. 19-31.

Miller, E.L., and Hudson, T.L., 1991, Mid-Cretaceous extensional fragmentation of a JurassicEarly Cretaceous compressional orogen, Alaska: Tectonics, v. 10, p. 781-796.

Miller, M.L., Belkin, H.E., Blodgett, R.B., Bundtzen, T.K., Cady, J.W., Goldfarb, R.J., Gray, J.E., McGimsey, R.G., and Simpson, S.L., 1989, Preliminary geologic map, Sleetmute quadrangle, Alaska: U.S. Geological Survey Open-File Report 89-363, scale 1:250,000, 115 p. 
Miller, M.L., Bradshaw, J.Y., Kimbrough, D.L., Stem, T.W., and Bundtzen, T.K., 1991, Isotopic evidence for Early Proterozoic age of the Idono Complex, west-central Alaska: Journal of Geology, v. 99, no. 2, p. 209-223.

Miller, M.L., and Bundtzen, T.K., 1994, Generalized geologic map of the Iditarod quadrangle, Alaska, showing potassium-argon, major oxide, trace-element, fossil, paleocurrent, and archeological sample localities: U.S. Geological Survey Map MF 2219-A, scale 1:250,000, 48 p.

Miyaoka, R.T., and Dover, J.H., 1985, Preliminary study of shear sense in mylonites, eastern Ray Mountains, Tanana quadrangle: U.S. Geological Survey Circular 967, p. 29-32.

Molenaar, C.M., 1982, Umiat field, an oil accumulation in a thrust-faulted anticline, North Slope of Alaska, in Powers, R.B., ed., Geologic Studies of the Cordilleran Thrust Belt: Rocky Mountains Association of Geologists, v. 2, p. 537-548.

Moll, E.J., Silberman, M.L., and Patton, W.W., Jr., 1981, Chemistry, mineralogy, and K-Ar ages of igneous and metamorphic rocks of the Medfra quadrangle, Alaska: U.S. Geological Survey Open-File Report 80-811C, 1 sheet, scale 1:250,000.

Moll-Stalcup, E.J., and Arth, J.G., 1989, The nature of the crust in the Yukon-Koyukuk province as inferred from the chemical and isotopic composition of five Late Cretaceous to early Tertiary volcanic fields in western Alaska, J. Geophys. Res., 15,989-16,020.

Moll-Stalcup, E.J., and Arth, J.G., 1992, Isotopic and chemical constraints on the petrogenesis of Blackburn Hills volcanic field, western Alaska: Geochimica et Cosmochimica Acta, v. 55, p. 3753-3716.

Moore, T.E., 1999, Balanced cross section, Bathtub syncline to Beaufort Sea through Niguanak structural high, Arctic National Wildlife Refuge (ANWR), northeastern Alaska, chap BC in ANWR Assessment Team, The Oil and Gas Resource Potential of the 1002 Area, Arctic National Wildlife Refuge, Alaska: U.S. Geological Survey Open-File Report 98-34, p. BC1BC61.

Moore, T.E., 2010, Detrital zircon U-Pb age populations in time and space in the Arctic Alaska terrane (T31A-2146) [abs.]: presented at 2010 Fall Meeting, American Geophysical Union, San Francisco, 13-17 December.

Moore, T.E., 2013, Structurally collapsed part of Laurentian margin in the northeastern Brooks Range, Arctic Alaska [abs.]: AAPG Polar Petroleum Potential Meeting, October 15-18, Stavanger Norway; American Association of Petroleum Geologists Search and Discovery, http://www.searchanddiscovery.com/abstracts/html/2013/90177arctic/abstracts/moore.html.

Moore, T.E., and Bird, K.J., 2009, Is the North Slope a displaced part of the Caledonian orogenic belt? [abs.]: AAPG Search and Discovery Article \#90096, AAPG Polar Petroleum Potential Arctic Conference and Exhibition, Moscow, Russia, http://www.searchanddiscovery.com/abstracts/html/2009/arctic/abstracts/moore03.htm?q=\%2 BtextStrip\%3A90096.

Moore, T.E., and Box, S.E., 2016 Age, distribution and style of deformation in Alaska north of $60^{\circ} \mathrm{N}$ : Implications for assembly of Alaska: Tectonophysics, 38 p., http://dx.doi.org/10.1016/j.tecto.2016.06.025.

Moore, T.E., Dumitru, T.A., Adams, K.E., Witebsky, S.N., and Harris, A.G., 2002, Origin of the Lisburne Hills-Herald arch structural belt-Stratigraphic, structural, and fission-track evidence from the Cape Lisburne area, northwestern Alaska, in Miller, E.L., and Grantz, A., eds., Tectonic evolution of the Bering Shelf-Chukchi Sea-Arctic Margin and adjacent landmasses: Geological Society of America Special Paper 360, p. 77-109. 
Moore, T.E., Grantz, A., and Roeske, S.M., 1994, Continent-ocean transition in Alaska: the tectonic assembly of eastern Denalia, in Speed, R.C., ed., Phanerozoic evolution of North America continent ocean transitions: Boulder, Colorado, Geological Society of America Decade of North American Geology Continent-Ocean Transect Volume, p. 399-441.

Moore, T.E., and O’Sullivan, P.B., 2013, Remnants in northeastern Alaska of part of a Devonian collisional zone from the northern margin of Laurentia [abs.]: Geological Society of America Abstracts with Programs, v. 45, p. 164.

Moore, T.E., O’Sullivan, P.B., Potter, C.J., and Donelick, R.A., 2015: Provenance and detrital zircon geochronologic evolution of lower Brookian foreland basin deposits of the western Brooks Range, Alaska, and implications for early Brookian tectonism: Geosphere, v. 11, p. 93-122, doi:10.1130/GES01043.1.

Moore, T.E., and Potter, C.J., 2008, Preliminary retrodeformable regional cross section, western Brooks Range, in Kelley, K.F., ed., Regional fluid flow and basin modeling in northern Alaska: U.S. Geological Survey Circular 1319, p. 28-31.

Moore, T.E., and Potter, C.J., 2011, Wedge-tip relations of the Early Cretaceous Brooks Range Deformation Front near the Dalton Highway [abs.]: AAPG Search and Discovery Article \#90125, AAPG Pacific Section Meeting, Anchorage, Alaska 8-11 May 2011.

Moore, T.E., Potter, C.J., O’Sullivan, P.B., Shelton, K.L., and Underwood, M.B., 2004, Two stages of deformation and fluid migration in the west-central Brooks Range fold and thrust belt, in Swennen, R., Roure, F., and Granath, W., eds., Deformation, Fluid Flow, and Reservoir Appraisal in Foreland Fold and Thrust Belts: American Association of Petroleum Geologists Hedberg Series, no. 1, p. 157-186.

Moore, T.E., Wallace, W.K., Bird, K.J., Karl, S.M., Mull, C.G., and Dillon, T.T., 1994, Geology of northern Alaska, in Plafker, G., and Berg, H.C., eds., The Geology of North America, v. G1, The Geology of Alaska: Boulder, Colorado, Geological Society of America, p. 49-140.

Moore, T.E., Wallace, W.K., Mull, C.G., Adams, K.E., Plafker, G., and Nokleberg, W.J., 1997, Crustal implications of bedrock geology along the Trans-Alaska Crustal Transect (TACT) in the Brooks Range, northern Alaska: Journal of Geophysical Research, v. 102, no. B9, p. 20,645-20,684.

Mortensen, J.K., and Dusel-Bacon, Cynthia, 2014, Nature and U-Pb zircon ages of midCretaceous calderas and tuffs in eastern Alaska and western Yukon-Implications for landscape evolution in the northern Cordillera [abs.]: Geological Society of America Abstracts with Programs, v. 46, no. 6, p. 794.

Mull, C.G., 1978, Apparent south-vergent folding and possible nappes in the Schwatka Mountains: U.S. Geological Survey Circular 751-B, p. B29-B31.

Mull, C.G., 1985, Cretaceous tectonics, depositional cycles, and the Nanushuk Group, Brooks Range and Arctic Slope, Alaska, in Huffman, A.C., ed., Geology of the Nanushuk Group and related rocks, North Slope, Alaska: U.S. Geological Survey Bulletin 1614, p. 7-36.

Mull, C.G., Adams, K.E., and Dillon, J.T., 1987, Stratigraphy and structure of the Doonerak fenster and Endicott Mountains allochthon, central Brooks Range, Alaska, in Tailleur, I.L, and Weimer, P., eds., Alaskan North Slope geology: Society of Economic Paleontologists and Mineralogists, Pacific Section, Publication 50, p. 663-680.

Mull, C.G., Glenn, R.K., and Adams, K.E., 1997, Tectonic evolution of the central Brooks Range mountain front-Evidence from the Atigun Gorge region: Journal of Geophysical Research, v. 102, p. 20,749-20,772. 
Mull, C.G., Harris, E.E., Delaney, P.R., and Swenson, R.F., 2009, Geologic map of the Cobblestone Creek-May Creek area, east-central Brooks Range foothills, Alaska: Alaska Division of Geological and Geophysical Surveys Preliminary Interpretive Report 2009-5, scale 1:63,360.

Mull, C.G., Houseknecht, D.W., and Bird, K.J., 2003, Revised Cretaceous and Tertiary stratigraphic nomenclature in the Colville Basin, northern Alaska: U.S. Geological Survey Professional Paper 1673, 51 p.

Mull, C.G., Houseknecht, D.W., Pessel, G.H., and Garrity, C.P., 2004, Geologic map of the Umiat quadrangle, Alaska: U.S. Geological Survey Scientific Investigations Map 2817-A, scale 1:250,000.

Mull, C.G., Houseknecht, D.W., Pessel, G.H., and Garrity, C.P., 2005, Geologic map of the Ikpikpuk River quadrangle, Alaska: U.S. Geological Survey Scientific Investigations Map 2817-B, scale 1:250,000.

Mull, C.G., Housknecht, D.W., Pessel, G.H., and Garrity, C.P., 2006a, Geologic map of the Lookout Ridge quadrangle, Alaska: U.S. Geological Survey Scientific Investigations Map 2817-C, scale 1:250,000.

Mull, C.G., Housknecht, D.W., Pessel, G.H., and Garrity, C.P., 2006b, Geologic map of the Utukok River quadrangle, Alaska: U.S. Geological Survey Scientific Investigations Map 2817-D, scale 1:250,000.

Mull, C.G., Houseknecht, D.W., Pessel, G.H., and Garrity, C.P., 2008, Geologic map of the Point Lay quadrangle, Alaska: U.S. Geological Survey Scientific Investigations Map 2817-E, scale $1: 250,000$.

Mull, C.G., Moore, T.E., Harris, E.E., and Tailleur, I.L., 1994, Geologic map of the Killik River quadrangle, Brooks Range: U.S. Geological Survey Open File Report 94-679, scale 1:250,000.

Murphy, J.M., 1987, Early Cretaceous cessation of terrane accretion, northern Eek Mountains, southwestern Alaska, in Hamilton, T.D., and Galloway. J.P., eds., Geologic studies in Alaska by the U.S. Geological Survey during 1986: U.S. Geological Survey Circular 998, p. 83-85.

Nelson, J.L., Colpron, M., Piercey, S.J., Dusel-Bacon, C., Murphy, D.C., and Roots, C.F., 2006, Paleozoic tectonic and metallogenetic evolution of pericratonic terranes in Yukon, northern British Columbia and eastern Alaska, in Colpron, M., and Nelson, J.L., eds., Paleozoic evolution and metallogeny of pericratonic terranes at the ancient Pacific margin of North America, Canadian and Alaskan Cordillera: Geological Association of Canada, Special Paper 45, p. 323-360.

Nelson, S.W., and Grybeck, Donald, 1980, Geologic map of the Survey Pass quadrangle, Brooks Range, Alaska: U.S. Geological Survey Miscellaneous Field Studies Map MF-1176A, scale $1: 250,000$.

Nelson, W.H., Carlson, C., and Case, J.E., 1983, Geologic map of the Lake Clark quadrangle, Alaska: U.S. Geological Survey Map MF 1114-A, scale 1:250,000.

Nokleberg, W.J., Jones, D.L., and Silberling, N.J., 1985, Origin, migration, and accretion of the Maclaren and Wrangellia terranes, eastern Alaska Range, Alaska: Geological Society of America Bulletin, v. 96, p. 1251-1270.

Nokleberg, W.J., Parfenov, L.M., Monger, J.W.H., Norton, I.O., Khanchuk, A.I., Stone, D.B., Scotese, C.R., Scholl, D.W., and Fujita, K., 2000, Phanerozoic tectonic evolution of the Circum-North Pacific: U.S. Geological Survey Professional Paper 1626, 122 p.

Nokleberg, W.J., Plafker, G., Lull, J.S., Wallace, W.K., and Winkler, G.R., 1989, Structural analysis of the southern Wrangellia, and northern Chugach terranes along the Trans-Alaska 
Crustal Transect, northern Chugach Mountains, Alaska: Journal of Geophysical Research, v. 94, p. 4297-4320.

Nokleberg, W.J., Plafker, G., and Wilson, F.H., 1994, Geology of south-central Alaska, in Plafker, G., and Berg, H.C., eds., The Geology of Alaska: Boulder, Colorado, Geological Society of America, Geology of North America, v. G-1, p. 311-366.

O’Neill, J.M., Ridgway, K.D., and Eastham, K.R., 2003, Mesozoic Sedimentation and Deformation Along the Talkeetna Thrust Fault, South-Central Alaska-New Insights and Their Regional Tectonic Significance, in Galloway, J.P., ed., Studies by the United States Geological Survey in Alaska in 2000: U.S. Geological Survey Professional Paper 1678, p. 8392.

O’Sullivan, P.B., 1996, Late Mesozoic and Cenozoic thermal-tectonic evolution of the North Slope foreland basin, Alaska, in Johnsson, M.J., and Howell, D.G., eds., Thermal Evolution of Sedimentary Basins in Alaska: U.S., Geological Survey Bulletin, v. 2142, p. 45-79.

O’Sullivan, P.B., Green, P.F., Bergman, S.C., Decker, J., Duddy, I.R., Gleadow, A.J.W., and Turner, D.L., 1993, Multiple phases of Tertiary uplift and erosion in the Arctic National Wildlife Refuge, Alaska, revealed by apatite fission track analysis: American Association of Petroleum Geologists Bulletin, v. 77, p. 359-385.

O’Sullivan, P.B., Kelley, K.D., and Jennings, S., 2000, Post-mineralization thermotectonic evolution of the region of the Red Dog Pb-Zn-Ag mine, northwest Alaska [abs.]: Geological Society of Australia Abstracts, v. 58, p. 255-257.

O’Sullivan, P.B., Moore, T.E., and Murphy, J.M., 1998a, Tertiary uplift of the Mt. Doonerak antiform, central Brooks Range, Alaska: apatite fission-track evidence from the Trans-Alaska crustal transect, in Oldow, J.S., and Avé Lallemant, H.G., eds., Architecture of the Central Brooks Range Fold and Thrust Belt, Arctic Alaska: Geological Society of America Special Paper 324, p. 179-193.

O’Sullivan, P.B., Murphy, J.M., and Blythe, A.E., 1997; Late Mesozoic and Cenozoic thermotectonic evolution of the central Brooks Range and adjacent North Slope foreland basin, Alaska-Including fission track results from the Trans-Alaska Crustal Transect (TACT): Journal of Geophysical Research, v. 102, p. 20,821-20,845.

O’Sullivan, P.B., and Wallace, W.K., 2002, Out-of-sequence, basement-involved structures in the Sadlerochit Mountains region of the Arctic National Wildlife Refuge, Alaska-Evidence and implications from fission-track thermochronology: Geological Society of America Bulletin, v. 114, p. 1356-1378.

O’Sullivan, P.B., Wallace, W.K., and Murphy, J.M., 1998b, Fission-track evidence for apparent out-of-sequence Cenozoic deformation along the Philip Smith mountain front, northeastern Brooks Range, Alaska: Earth and Planetary Science Letters, v 164, p. 435-449.

Oldow, J.S., Avé Lallemant, H.G., Julian, F.E., and Seidensticker, C.M., 1987, Ellesmerian(?) and Brookian deformation in the Franklin Mountains, northeast Brooks Range, Alaska and its bearing on the origin of the Canada basin: Geology, v. 15, p. 37-41.

Page, R.A., Biswas, N.N., Lahr, J.C., and Pulpan, H., 1991, Seismicity of continental Alaska, in Slemmons, D.B., Engdahl, E.R., Zoback, M.C., and Blackwell, D.D., eds., Neotectonics of North America: Boulder, Colorado, Geological Society of America, Geology of North America Map Volume 1, p. 47-68.

Page, R.A., Plafker, G., and Pulpan, H., 1995, Block rotation in east-central Alaska-A framework for evaluating earthquake potential?: Geology, v. 23, p. 629-632. 
Pallister, J.S., Budahn, J.R., and Murchey, B.L., 1989, Pillow basalts of the Angayucham terrane-Oceanic-plateau and island crust accreted to the Brooks Range: Journal of Geophysical Research, v. 94, p. 15,901-15923.

Parris, T.M., Burruss, R.C., and O’Sullivan, P.B., 2003, Deformation and the timing of gas generation and migration in the eastern Brooks Range foothills, Arctic National Wildlife Refuge, Alaska: American Association of Petroleum Geologists Bulletin, v. 87, p. 1823-1846.

Patrick, B.E., 1988, Synmetamorphic structural evolution of the Seward Peninsula blueschist terrane, Alaska: Journal of Structural Geology, v. 10, p. 555-565.

Patton, W.W., Jr., and Box, S.E., 1989, Tectonic Setting of the Yukon-Koyukuk Basin and Its Borderlands, Western Alaska: Journal of Geophysical Research, v. 94, no. B11, p. 15,807$15,820$.

Patton, W.W., Jr., Box, S.E., and Grybeck, D.J., 1994a, Ophiolites and other mafic-ultramafic complexes in Alaska, in Plafker, G., and Berg, H.C., eds., The Geology of Alaska: Boulder, Colorado, Geological Society of America, The Geology of North America, v. G-1, p. 671-686.

Patton, W.W., Jr., Box, S.E., Moll-Stalcup, E.J., and Miller, T.P., 1994b, Geology of westcentral Alaska, in Plafker, G., and Berg, H.C., eds., The Geology of Alaska: Boulder, Colorado, Geological Society of America, The Geology of North America, v. G-1, p. 241-269.

Patton, W.W., Jr., Box, S.E., and Grybeck, D.J., 1994c, Ophiolites and other mafic-ultramafic complexes in Alaska, in Plafker, G., and Berg, H.C., eds., The Geology of Alaska: Boulder, Colorado, Geological Society of America, The Geology of North America, v. G-1, p. 671-686.

Patton, W.W., Jr., and Csejtey, Bela, Jr., 1980, Geologic map of St. Lawrence Island, Alaska: U.S. Geological Survey Miscellaneous Investigations Series Map I-1203.

Patton, W.W., Jr., Miller, T.P., Chapman, R.M., and Yeend, W., 1978, Geologic map of the Melozitna quadrangle, Alaska: U.S. Geological Survey Miscellaneous Investigations Series Map I-1071, 1 sheet, scale 1:250,000.

Patton, W.W., Jr., Moll, E.J., Dutro, J.T., Jr., Silberman, M.L., and Chapman, R.M., 1980, Preliminary geologic map of the Medfra quadrangle, Alaska: U.S. Geological Survey Open File Report 80-811A, scale: 1:250,000.

Patton, W.W., Jr., and Moll-Stalcup, E.J., 1996, Geologic map of the Unalakleet quadrangle, west-central Alaska: U.S. Geological Survey Miscellaneous Investigations Map I-2559, scale 1:250,000, 39 p.

Patton, W.W., Jr., Wilson, F.H., and Labay, K.A., 2006, Reconnaissance geologic map of the Lower Yukon River region: U.S. Geological Survey Open-File Report 2006-1292, scale 1:500,000, http://pubs.usgs.gov/of/2006/1292/.

Patton, W.W., Jr., Wilson, F.H., Labay, K.A., and Shew, N., 2009, Geologic Map of the YukonKoyukuk Basin, Alaska: U.S. Geological Survey Scientific Investigations Map 2909, scale 1:500,000, 26 p.

Pavlis, T.L., 1989, Middle Cretaceous orogenesis in the northern Cordillera-A Mediterranean analog of collision related extensional tectonics: Geology, v. 17, p. 947-950.

Pavlis, T.L., Chapman, J.B., Bruhn, R.L., Ridgway, K., Worthington, L.L., Gulick, S.P.S, and Spotila, J., 2012, Structure of the actively deforming fold-thrust belt of the St. Elias orogeny with implications for glacial exhumation and three-dimensional tectonic processes: Geosphere, v. 8, p. 991-1019.

Pavlis, T.S., Monteverde, D.H., Bowman, J.R., Rubenstone, J.L., and Reason, M.D., 1988, Early Cretaceous near-trench plutonism in southern Alaska-A tonalite-trondhjemite intrusive 
complex injected during ductile thrusting along the Border Ranges fault system: Tectonics, v. 7, p. 1179-1199.

Pavlis, T.L., Picornell, C., and Serpa, L., 2004, Tectonic processes during oblique collisionInsights from the St. Elias orogeny, northern North American Cordillera: Tectonics, v. 23, 14 p., doi:10.1029/2003TC001557.

Pavlis, T.L., and Roeske, S.M., 2007, The Border Ranges fault system, southern Alaska, in Ridgway, K.D., Trop, J.M., Glen, J.M.G., and O’Neill, J.M., eds., Tectonic Growth of a Collisional Continental Margin-Crustal Evolution of Southern Alaska: Geological Society of America Special Paper 431, p. 95-127.

Pavlis, T.L., and Sisson, V.B., 1995, Structural history of the Chugach metamorphic complex in the Tana River region, eastern Alaska-A record of Eocene ridge subduction: Geological Society of America Bulletin, v. 107, p. 1333-1355.

Pavlis, T.L., and Sisson, V.B., 2003, Development of a subhorizontal decoupling horizon in a transpressional system, Chugach metamorphic complex, Alaska-Evidence for rheological stratification of the crust, in Sisson, V.B., Roeske, S.M., and Pavlis, T.L., eds., Geology of a transpressional orogeny developed during ridge-trench interaction along the North Pacific margin: Boulder, Colorado, Geological Society of America Special Paper 371, p. 191-216.

Pavlis, T.L., Sisson, V.B., Foster, H.L., Nokleberg, W.J., and Plafker, G., 1993, Mid-Cretaceous extensional tectonics of the Yukon-Tanana terrane, Trans-Alaska Crustal Transect (TACT), east-central Alaska: Tectonics, v. 12, p. 103-122.

Peapples, P.R., Wallace, W.K., Wartes, M.A., Swenson, R.F., Mull, C.G., Dumoulin, J.A., Harris, E.E., Finzel, E.S., Reifenstuhl, R.R., and Loveland, A.M., 2007, Geologic map of the Siksikpuk River area, Chandler Lake quadrangle, Alaska: Alaska Division of Geological and Geophysical Surveys Preliminary Interpretive Report 2007-1, scale 1:63,360.

Petrov, O., Smelror, M., Shokalsky, S., Morozov, A., Kashubin, S., Grikurov, G., Sobolev, N., Petrov, E., 2013, A new international tectonic map of the Arctic (TeMAr) at 1:5 M scale and geodynamic evolution in the Arctic region [abs.]: Geophysical Research Abstracts, v. 15, EGU2013-13481, presented at European Geophysical Union, 7-12 April 2013, Vienna, Austria, p. 13481.

Plafker, G., and Berg, H.C., 1994, Overview of the geology and tectonic evolution of Alaska, in Plafker, G., and Berg, H.C., eds., The Geology of Alaska: Boulder, Colorado, Geological Society of America, The Geology of North America, v. G-1, p. 989-1021.

Plafker, G., Moore, J.C., and Winkler, G.R., 1994, Geology of the southern Alaska margin, in Plafker, G., and Berg, H.C., eds., The Geology of Alaska: Boulder, Colorado, Geological Society of America, The Geology of North America, v. G-1, p. 389-449.

Plafker, G., Nokleberg, W.J., and Lull, J.S., 1989, Bedrock geology and tectonic evolution of the Wrangellia, Peninsular, and Chugach terranes along the trans-Alaska crustal transect in the northern Chugach Mountains and southern Copper River basin: Journal of Geophysical Research, v. 94, p. 4255-4295.

Popov, L.Y., Blodgett, R.B., and Anderson, A.V., 1994, First occurrence of the Genus

Bicarinatina (Brachiopoda, Inarticulata) from the Middle Devonian in North America (Alaska): Journal of Paleontology, v. 68, p. 1214-1218.

Potter, C.J., Grow, J.A., Perry, W.J., Moore, T.E., O’Sullivan, P.B., Phillips, J.D., and Saltus, R.W., 2004, Tertiary thrust systems and fluid flow beneath the Beaufort coastal plain (1002 Area), Arctic National Wildlife Refuge, Alaska, U.S.A, in Swennen, R., Roure, F., and Granath, W., eds., Deformation, Fluid Flow, and Reservoir Appraisal in Foreland Fold and 
Thrust Belts: American Association of Petroleum Geologists Hedberg Series, no. 1, p. 187214.

Potter, C.J., and Moore, T.E., 2003, Brookian structural plays in the National Petroleum Reserve, Alaska: U.S. Geological Survey Open-File Report 03-266, 49 p., http://geopubs.wr.usgs.gov/open-file/of03-266/.

Reiser, H.N., Brosgé, W.P., Dutro, J.T., Jr., and Detterman, R.L., 1980, Geologic map of the Demarcation Point quadrangle, Alaska: U.S. Geological Survey Miscellaneous Investigations Series Map I-1133, scale 1:250,000, 1 sheet.

Reiser, H.N., Brosgé, W.P. Dutro, J.T., Jr., and Detterman, R.L., 1971, Preliminary geologic map, Mt. Michelson quadrangle, Alaska: U.S. Geological Survey Open File Report 71-237, 2 sheets, scale 1:250,000.

Reiser, H.N., Lanphere, M.A., and Brosgé, W.P., 1966, Jurassic age of a mafic igneous complex, Christian quadrangle, Alaska: U.S. Geological Survey Professional Paper 525-C, p. C68-C71.

Reifenstuhl, R.R., Dover, J.H., Newberry, R.J., Clautice, K.H., Liss, S.A., Blodgett, R.B., Bundtzen, T.K., and Weber, F.R., 1997, Interpretive geologic bedrock map of the Tanana B-1 quadrangle, central Alaska: Alaska Division of Geological and Geophysical Surveys Report of Investigations 97-15b, 17 p., 1 sheet scale 1:63,360

Reifenstuhl, R.R., Dover, J.H., Newberry, R.J., Clautice, K.H., Liss, S.A., Blodgett, R.B., and Weber, F.R., 1998, Interpretive geologic bedrock map of the Tanana A-1 and A-2 quadrangles, central Alaska: Alaska Division of Geological and Geophysical Surveys Public-Data File 9837b, version 1.1, 16 p., 1 sheet, scale 1:63,360.

Riccio, S.J., Fitzgerald, P.G., Benowitz, J.A., and Roeske, S.M., 2014, The role of thrust faulting in the formation of the eastern Alaska Range-Thermochronological constraints from the Susitna Glacier Thrust Fault region of the intracontinental strike-slip Denali Fault system: Tectonics, v. 33, p. 2195-2217, doi:10.1002/2014TC003646.

Richter, D.H., Lanphere, M.A., and Matson, N.A., Jr., 1975, Granitic Plutonism and Metamorphism, Eastern Alaska Range, Alaska: Geological Society of America Bulletin, v. 86, p. 819-829.

Ridgway, K.D., Trop, J.M., Nokleberg, W.J., Davidson, C.M., and Eastham, K.D., 2002, Mesozoic and Cenozoic tectonics of the eastern and central Alaska Range-Progressive basin development and deformation within a suture zone: Geological Society of America Bulletin, v. 114, p. 1480-1504.

Rioux, M., Hacker, B., Mattinson, J., Kelemen, P., Blusztajy, J., and Gehrels, G., 2007, Magmatic development of an intra-oceanic arc-High-precision U-Pb zircon and whole-rock isotopic analyses from the accreted Talkeetna arc, south-central Alaska: Geological Society of America Bulletin, v. 119, p. 1168-1184.

Robinson, M.S., Smith, T.E., and Metz, P.A., 1990, Bedrock geology of the Fairbanks Mining district: Alaska Division of Geological and Geophysical Surveys Professional Report 106, 2 sheets, scale 1:63,360.

Roeske, S.M., Dusel-Bacon, C., Aleinikoff, J.N., Snee, L.W., and Lanphere, M.A., 1995, Metamorphic and structural history of continental crust at a Mesozoic collisional margin, the Ruby terrane, central Alaska, in Patrick, B.E., and Day, H.W., eds., Special issue on Cordilleran high-pressure metamorphic terranes: Journal of Metamorphic Geology, v. 13, p. 25-40.

Roeske, S.M., Mattinson, J.M., and Armstrong, R.L., 1989, Isotope ages of glaucophane schists on the Kodiak Islands, southern Alaska, and their implications for the Mesozoic tectonic 
history of the Border Ranges fault system: Geological Society of America Bulletin, v. 101, p. 1021-1037.

Roeske, S.M., and McClelland, W.C., 1997, Preservation of the subduction zone boundary between the Ruby terrane and Tozitna terrane, west-central Alaska: Geological Society of America Abstracts with Programs, v. 29, no. 5, p. 60.

Roeske, S.M., McClelland, W.C., and Koepele, P., 1998, Late Early Cretaceous transtension in the Ruby terrane, west-central Alaska [abs.]: Geological Society of America Abstracts with Programs, v. 30, no. 7, p. 176.

Roeske, S.M., McClelland, W.C., and Till, A.B., 2015: Generation of the Ruby batholith, northcentral Alaska, by an Early Cretaceous short-lived voluminous intrusive event [abs.]: Geological Society of America Abstracts with Programs v. 47, no. 4, p. 1.

Rohr, D.M., Blodgett, R.B., and Beckstead, D., 2008, Paleogeography of Woodchopper Volcanics, Yukon-Charley Rivers National Preserve, Alaska: Alaska Park Science, v. 7, no. 1, p. 23-27.

Sable, E.G., Mangus, M.D., Morris, R.H., and Dutro, J.T., Jr.., 1984, Geologic map of the eastcentral Kukpowruk-Nuka Rivers Region, northwestern Alaska: U.S. Geological Survey Miscellaneous Field Studies Map MF-1670, 2 sheets, scale 1:63,360.

St. Amand, P., 1957, Geological and geophysical synthesis of the tectonics of portions of British Columbia, the Yukon Territory, and Alaska: Geological Society of America Bulletin, v. 68, p. 1343-1370.

Scharman, M.R., Pavlis, T.L., Day, E.M., and O’Driscoll, L.J., 2011, Deformation and structure in the Chugach metamorphic complex, southern Alaska-Crustal architecture of a transpressional system from a down plunge section: Geosphere, v. 7, p. 992-1012.

Seidensticker, C.M., and Oldow, J.S., 1998, Structural development and kinematic history of ramp-footwall contraction in the Doonerak multiduplex, central Brooks Range, Arctic Alaska, in Oldow, J.S., and Avé Lallemant, H.G., eds., Architecture of the Central Brooks Range Fold and Thrust Belt, Arctic Alaska: Geological Society of America Special Paper 324, p. 81-108.

Sherwood, K.W., Johnson, P.P., Craig, J.D., Zerwick, S.A., Lothamer, R.T., Thurston, D.K., and Hurlber, S.B., 2002, Structure and stratigraphy of the Hanna Trough, U.S. Chukchi Shelf, Alaska, in Miller, E.L., Grantz, A., and Klemperer, S.L., eds., Tectonic evolution of the Bering Shelf-Arctic Margin and Adjacent Landmasses: Geological Society of America Special Paper 360, p. 39-66.

Silberling, N.J., Jones, D.L., Monger, J.W.H., and Coney, P.J., 1992, Lithotectonic terrane map of the North American Cordillera: U.S. Geological Survey Miscellaneous Investigations Map I-2176, scale 1:5,000,000.

Sisson, V.B., and Onstott, T.C., 1986, Dating blueschist metamorphism-A combined ${ }^{40} \mathrm{Ar} /{ }^{39} \mathrm{Ar}$ and electron microprobe approach: Geochimica et Cosmochimica Acta, v. 50, p. 2111-2117.

Solie, D.N., and Mull, C.G., 1991, Kikiktat Mountain klippe-A link between the Copter Peak and Nuka Ridge allochthons, northcentral Brooks Range, Alaska, in Reger, R.D., ed., Short notes on Alaskan geology, 1991: Alaska Division of Geological and Geophysical Surveys Professional Report 111, p. 77-88.

Stanley, R.G., Haeussler, P.J., Benowitz, J.A., Lewis, K.A., Shellenbaum, D.P., Saltus, R.W., Shah, A.K., Phillips, J.D., and Potter, C.J., 2014, Tectonic implications of new geological and geophysical results from the Susitna basin, south-central Alaska [abs.]: American Association of Petroeum Geologists Search and Discovery Article \#10608, 2 p. 
Stanley, R.G., Till, A.B., Simpson, M.K., Schenk, C.J., Saltus, R.W., Rowan, E.L., Phillips, J.D., Morin, R.L., Lillis, P.G., and Crews, J.M., 2005, Assessment of undiscovered oil and gas resources in Yukon Flats, east-central Alaska [abs.]: Geological Society of America Abstracts with Programs, v. 37, no. 4, p. 95, Pacific Section, American Association of Petroeum Geologists and Cordilleran Section GSA, Joint Meeting, San Jose, California. http://gsa.confex.com/gsa/2005CD/finalprogram/abstract_85058.htm.

Staples, R.D., Gibson, H.D., Berman, R.G., Berman, R.G., Ryan, J.J., and Colpron, M., 2013, A window into the Early to mid-Cretaceous infrastructure of the Yukon-Tanana terrane recorded in multi-stage garnet of west-central Yukon, Canada: Journal of Metamorphic Geology, v. 31, p. 729-753.

Strauss, J.V., Macdonald, F.A., Taylor, J.F., Repetski, J.E., and McClelland, W.C., 2013, Laurentian origin for the North Slope of Alaska-Implications for the tectonic evolution of the Arctic: Lithosphere, v. 5, p. 477-482.

Tempelman-Kluit, D.J., 1979, Transported cataclasite, ophiolite and granodiorite in YukonEvidence of arc-continent collision: Geological Survey of Canada Paper 79-14, 27p.

Thurston, S.P., 1985, Structure, petrology, and metamorphic history of the Nome Group blueschist terrane, Salmon Lake area, Seward Peninsula, Alaska: Geological Society of America Bulletin, v. 96, p. 600-617.

Till, A.B., Dumoulin, J.A., Ayuso, R.A., Aleinikoff, J.N., Amato, J.M., Slack, J.F., and Shanks, W.C.P., III, 2014, Reconstruction of an early Proterozoic continental margin based on the nature of protoliths in the Nome Complex, Seward Peninsula, Alaska, in Dumoulin, J.A., and Till, A.B., eds., Reconstruction of a Late Proterozoic to Devonian Continental Margin Sequence, Northern Alaska, Its Paleogeographic Significance, and Contained Base-Metal Sulfide Deposits: Geological Society of America Special Paper 506, p. 1-28.

Till, A.B., Dumoulin, J.A., Harris, A.G., Moore, T.E., Bleick, H.A., and Siwiec, B.R., 2008, Bedrock geologic map of the southern Brooks Range, Alaska, and accompanying conodont data: U.S. Geological Survey Open-File Report 2008-1149, 2 sheets, 88 p.

Till, A.B., Dumoulin, J.A., Phillips, J.D., Stanley, R.G., and Crews, J.M., 2006, Generalized bedrock geologic map, Yukon Flats region, east-central Alaska: U.S. Geological Survey OpenFile Report 2006-1304, 25 p., scale 1:500,000.

Till, A.B., Dumoulin, J.A., Werdon, M.B., and Bleick, H.A., 2011, Bedrock Geologic Map of the Seward Peninsula, Alaska, and Accompanying Conodont Data: U.S. Geological Survey Scientific Investigations Map 3131, scale 1:500,000, 75 p.

Till, A.B., and Roeske, S.M., 2015, Accommodation of Mesozoic rotational opening of Canada Basin-The role of the Ruby terrane: Geological Society of America Abstracts with Programs, v. 47, no. 4, p. 1.

Till, A.B., Roeske, S.M., Bradley, D.C., Friedman, F. and Layer, P.W., 2007, Early Tertiary transtension-related deformation and magmatism along the Tintina fault system, Alaska, in Till, A.B., Roeske, S.M., Sample, J.C., and Foster, D.A., eds., Exhumation Associated with Continental Strike-Slip Fault Systems: Geological Society of America Special Paper 434, p. 233-264.

Till, A.B., Schmidt, J.M., and Nelson, S.W., 1988, Thrust involvement of metamorphic rocks, southwestern Brooks Range, Alaska: Geology, v. 16, p. 930-933.

Till, A.B., and Snee, L.W., 1995, ${ }^{40} \mathrm{Ar} /{ }^{39} \mathrm{Ar}$ evidence that deformation of blueschists in continental crust was synchronous with foreland fold and thrust belt deformation, western 
Brooks Range, Alaska, in Patrick, B.E., and Day, H.W., eds., Special issue on Cordilleran high-pressure metamorphic terranes: Journal of Metamorphic Geology, v. 13, p. 41-60.

Toro, J., Gans, P.B., McClelland, W.C., and Dumitru, T.A., 2002, Deformation and exhumation of the Mount Igikpak region, central Brooks Range, Alaska, in Miller, E.L., and Grantz, A., eds., Tectonic evolution of the Bering Shelf-Chukchi Sea-Arctic Margin and adjacent landmasses: Geological Society of America Special Paper 360, p. 111-132.

Trop, J.M., and Ridgway, K.D., 2007, Mesozoic and Cenozoic tectonic growth of southern Alaska-A sedimentary basin perspective, in Ridgway, K.D., Trop, J.M., Glen, J.M.G., and O’Neill, J.M., eds., Tectonic Growth of a Collisional Continental Margin-Crustal Evolution of Southern Alaska: Geological Society of America Special Paper 431, p. 55-94.

Trop, J.M., Ridgway, K.D., Manuszak, J.D., and Layer, P.W., 2002, Sedimentary basin development on the allochthonous Wrangellia composite terrane, Mesozoic Wrangell Mountains basin, Alaska-A long-term record of terrane migration and arc construction: Geological Society of America Bulletin, v. 114, p. 693-717.

Trop, J.M., Ridgway, K.D., and Spell, T.L., 2003, Sedimentary record of transpressional tectonics and ridge subduction in the Tertiary Matanuska Valley-Talkeetna Mountains forearc basin, southern Alaska, in Sisson, V.B., Roeske, S.M., and Pavlis, T.L., eds., Geology of a transpressional orogen developed during ridge-trench interaction along the North Pacific margin: Boulder, Colorado, Geological Society of America Special Paper 371, p. 89-118.

Trop, J.M., Ridgway, K.D., and Sweet, A.R., 2004, Stratigraphy, palynology, and provenance of the Colorado Creek basin, Alaska, U.S.A.-Oligocene transpressional tectonics along the central Denali fault system: Canadian Journal of Earth Sciences, v. 41, p. 457-480.

Trop, J.M., Szuch, D.A., Rioux, M., and Blodgett, R.B., 2005, Sedimentology and provenance of the Upper Jurassic Naknek Formation, Talkeetna Mountains, Alaska-Bearings on the accretionary tectonic history of the Wrangellia composite terrane: Geological Society of America Bulletin, v. 117, nos. 5,6, p. 570-588.

Turner, D.L., Forbes, R.B., Aleinikoff, J.N., McDougall, I., and Hedge, C.E., 2009, Geologic and Geochronologic Studies of the Early Proterozoic Kanektok Metamorphic Complex of Southwestern Alaska: U.S. Geological Survey Open File Report 2009-1248, 45 p.

Tuzzolino, A.L., Newberry, R.J., and Freeman, L.K., 2014, The No Name pluton-A potential rare-earth element (REE) resource in the Ruby batholith, Alaska (presentation at Alaska Miners Association, 245h Biennial Mining Conference, Fairbanks, Alaska, April 7-13, 2014): Alaska Division of Geological \& Geophysical Surveys, 30 p. doi:10.14509/27286.

Tysdal, R.G., and Case, J.E., 1979, Geologic map of the Seward and Blying Sound quadrangles, Alaska: U.S. Geological Survey Miscellaneous Investigations Map I-1150, 12 p., scale $1: 250,000$.

Vogl, J.J., 2002, Late-orogenic backfolding and extension in the Brooks Range collisional orogeny, northern Alaska: Journal of Structural Geology, v. 24, p. 1753-1776.

Vogl, J.J., 2003, Thermal-baric structure and P-T history of the Brooks Range metamorphic core, Alaska: Journal of Metamorphic Geology, v. 21, p. 269-284.

Vogl J.J., Calvert, A.T., and Gans, P.B., 2002, Mechanisms and timing of exhumation of collision-related metamorphic rocks, southern Brooks Range, Alaska-Insights from ${ }^{40} \mathrm{Ar} /{ }^{39} \mathrm{Ar}$ thermochronology: Tectonics, v. 21, 17 p., doi:10.1029/2000TC001270.

Wallace, W.K., 2008, Yakataga fold-and-thrust belt-Structural geometry and tectonic implications of a small continental collisional zone, in Freymueller, J.T., Haeussler, P.J., 
Wesson, R.L., Ekström, G., eds., Tectonics and seismic hazards of Alaska: American Geophysical Union Geophysical Monograph 179, p. 237-256, doi:10.1029/179GM13.

Wallace, W.K., and Hanks, C.L., 1990, Structural provinces of the northeastern Brooks Range, Arctic National Wildlife Refuge, Alaska: American Association of Petroleum Geologists Bulletin, v. 74, p. 1100-1118.

Wallace, W.K., Moore, T.E., and Plafker, G., 1997, Multistory duplexes with forward dipping roofs, north central Brooks Range, Alaska: Journal of Geophysical Research, v. 102, p. 20,773-20,796.

Weber, F.R., Wheeler, K.L., Rinehart, C.D., Chapman, R.M., and Blodgett, R.B., 1992, Geologic map of the Livengood Quadrangle, Alaska: U.S. Geological Survey Open-File Report 92-562, 20 p., 1 sheet, scale 1:250,000.

Winkler, G.R., 1992, Geologic map, cross sections, and summary geochronology of the Anchorage quadrangle, southern Alaska: U.S. Geological Survey Miscellaneous Investigations Map I-2283, scale 1:250,000.

Winkler, G.R., and Plafker, G., 1981, Geologic map and cross sections of the Cordova and Middleton Island quadrangles, southern Alaska: U.S. Geological Survey Open File Report 811164, scale 1:250,000.

Winkler, G.R., Silberman, M.L., Grantz, A., Miller, R.J., and MacKevett, E.M., Jr., 1981, Geologic map and summary geochronology of the Valdez quadrangle, southern Alaska: U.S. Geological Survey Open File Report 80-892-A, scale 1:250,000, 2 sheets.

Worthington, L.L., Van Avendonk, H.J.A., Gulick, S.P.S., Christeson, G.L., and Pavlis, T.L., 2012, Crustal structure of the Yakutat terrane and the evolution of subduction and collision in southern Alaska, Journal of Geophysical Research, v. 117, B01102, doi:10.1029/2011JB008493. 


\begin{tabular}{|c|c|c|c|c|c|c|}
\hline \multirow{5}{*}{ Cenozoic } & \multicolumn{2}{|c|}{$\begin{array}{l}\text { TIME-SLICE } \\
\text { INTERVAL }\end{array}$} & MA & STAGE & EPOCH & $\begin{array}{c}\text { PERIOD } \\
\text { Ouaternary }\end{array}$ \\
\hline & \multirow{3}{*}{ C } & C3 & \multirow{3}{*}{$\begin{array}{l}15 \\
34 \\
66\end{array}$} & & Miocene & Neogene \\
\hline & & $\mathrm{C} 2$ & & & Oligocene & \multirow[b]{2}{*}{ Paleogene } \\
\hline & & C1 & & -ーーーー & Paleocene & \\
\hline & \multirow{3}{*}{ LM } & LM3 & \multirow{3}{*}{$\begin{array}{c}86 \\
113 \\
145\end{array}$} & Santonian & Late & \multirow{3}{*}{ Cretaceous } \\
\hline \multirow{3}{*}{$\begin{array}{l}\text { Late } \\
\text { Mesozoic }\end{array}$} & & LM2 & & $\begin{array}{l}\text { Coniacian } \\
\text { Albian }\end{array}$ & ------ & \\
\hline & & LM1 & & $\bar{A} \overline{p t i a n}-$ & Early & \\
\hline & \multirow{3}{*}{ EM } & EM3 & \multirow{4}{*}{$\begin{array}{l}170 \\
201 \\
252\end{array}$} & Bajocian & $--\frac{\text { Late }}{\text { Middle }}$ & \multirow{2}{*}{ Jurassic } \\
\hline \multirow{3}{*}{$\begin{array}{c}\text { Early } \\
\text { Mesozoic }\end{array}$} & & EM2 & & Aalean & Early & \\
\hline & & EM1 & & & & Triassic \\
\hline & \multirow{4}{*}{ LP } & LP4 & & & & Permian \\
\hline \multirow{5}{*}{$\begin{array}{c}\text { Late } \\
\text { Paleozoic }\end{array}$} & & LP3 & \multirow{4}{*}{$\begin{array}{l}299 \\
323 \\
347 \\
383\end{array}$} & & & Pennsylvanian \\
\hline & & LP2 & & Visean & $-\frac{\text { Late }}{\text { Middle }}$ & Mississippian \\
\hline & & LP1 & & $\begin{array}{l}\text { Tournaisian } \\
\text { Frasnian }\end{array}$ & $\begin{array}{l}\text { Early } \\
\text { Late }\end{array}$ & \\
\hline & \multirow{4}{*}{ EP } & & & Givetian & Middle & Devonian \\
\hline & & EP3 & \multirow{4}{*}{$\begin{array}{l}444 \\
485 \\
541\end{array}$} & & Early & Silurian \\
\hline \multirow{3}{*}{$\begin{array}{c}\text { Early } \\
\text { Paleozoic }\end{array}$} & & EP2 & & & & Ordovician \\
\hline & & EP1 & & & & Cambrian \\
\hline & \multirow{3}{*}{$P$} & P3 & & & & Neoproterozoic \\
\hline \multirow[t]{2}{*}{ Proterozoic } & & $\mathrm{P} 2$ & \multirow{3}{*}{$\begin{array}{l}1000 \\
1600 \\
2500\end{array}$} & & & Mesoproterozoic \\
\hline & & P1 & & & & Paleoproterozoic \\
\hline Archean & A & & & & & Archean \\
\hline
\end{tabular}

Figure 1. Time scale from Cohen and others (2013) divided into 20 labeled time intervals defined by the working group for the Tectonic Map of the Arctic and adjusted to fit the geology of Alaska. Deformational episodes identified in Alaska are assigned to 14 of these time intervals according to their ages of deformation as summarized in table 1. Time intervals with deformational events in Alaska are colored; time intervals lacking deformational events in Alaska are uncolored. 


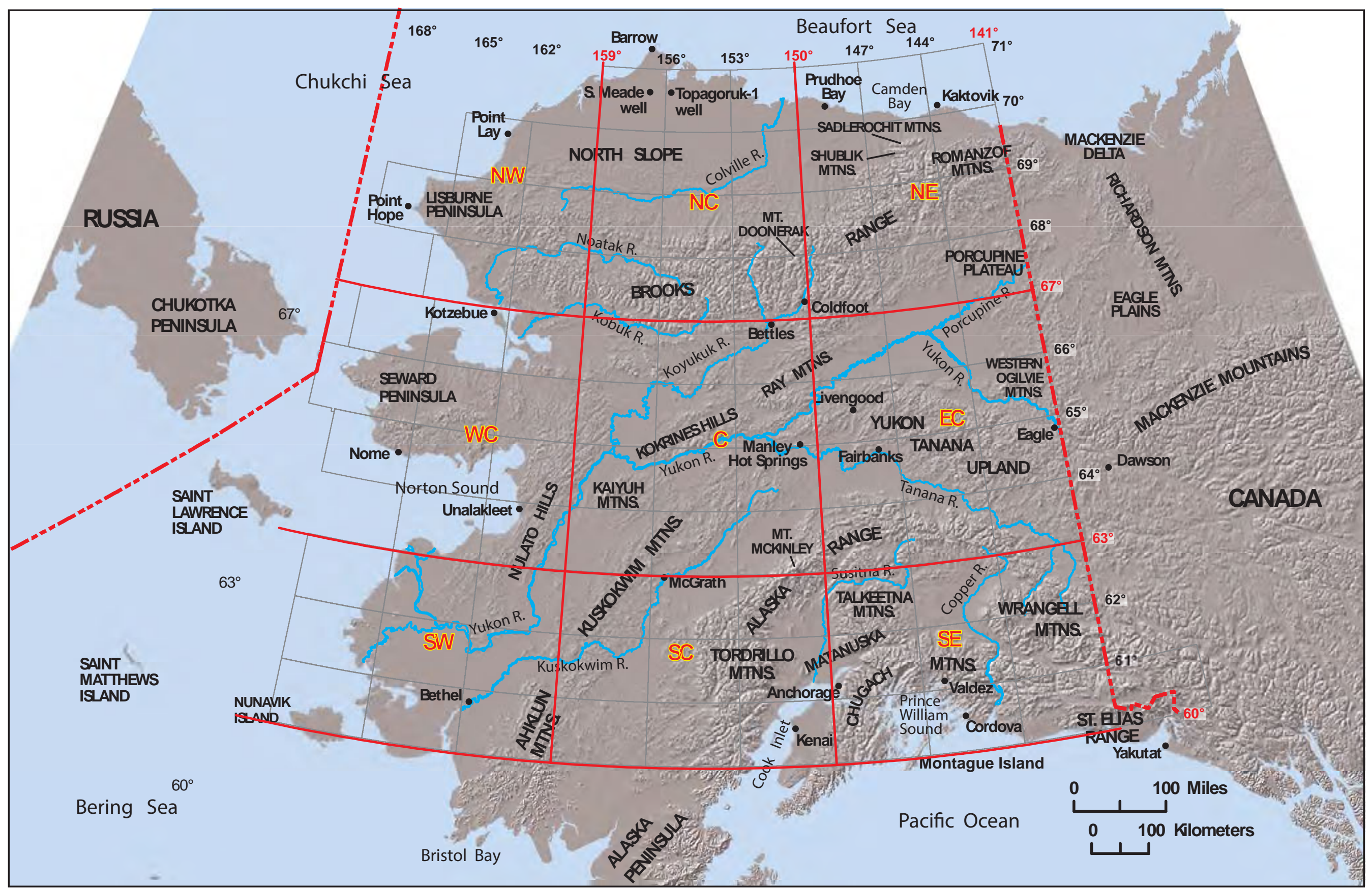

Figure 2. Physiographic map of Alaska north of latitude $60^{\circ} \mathrm{N}$. and adjacent area, showing important cities and towns, major rivers, and geographic features referred to in this paper. Red lines divide the State into nine subareas or quadrants that are used in tables 1 and 2 to locate areas of shared deformation (lines at latitudes $60^{\circ}, 63^{\circ}$, and $67^{\circ} \mathrm{N}$. and longitudes $150^{\circ}$ and $159^{\circ} \mathrm{W}$.; international borders at longitudes $141^{\circ}$ and $169^{\circ} \mathrm{W}$. [part] are also shown). Also shown is grid of $3^{\circ}$ quadrangles for Alaska (see Plafker and Berg, 1994, their fig. 3 , for quadrangle names). NW, northwest; NC, north-central; NE, northeast; WC, west-central; C, central; EC, east-central; SW, southwest; SC, south-central; SE, southeast. 


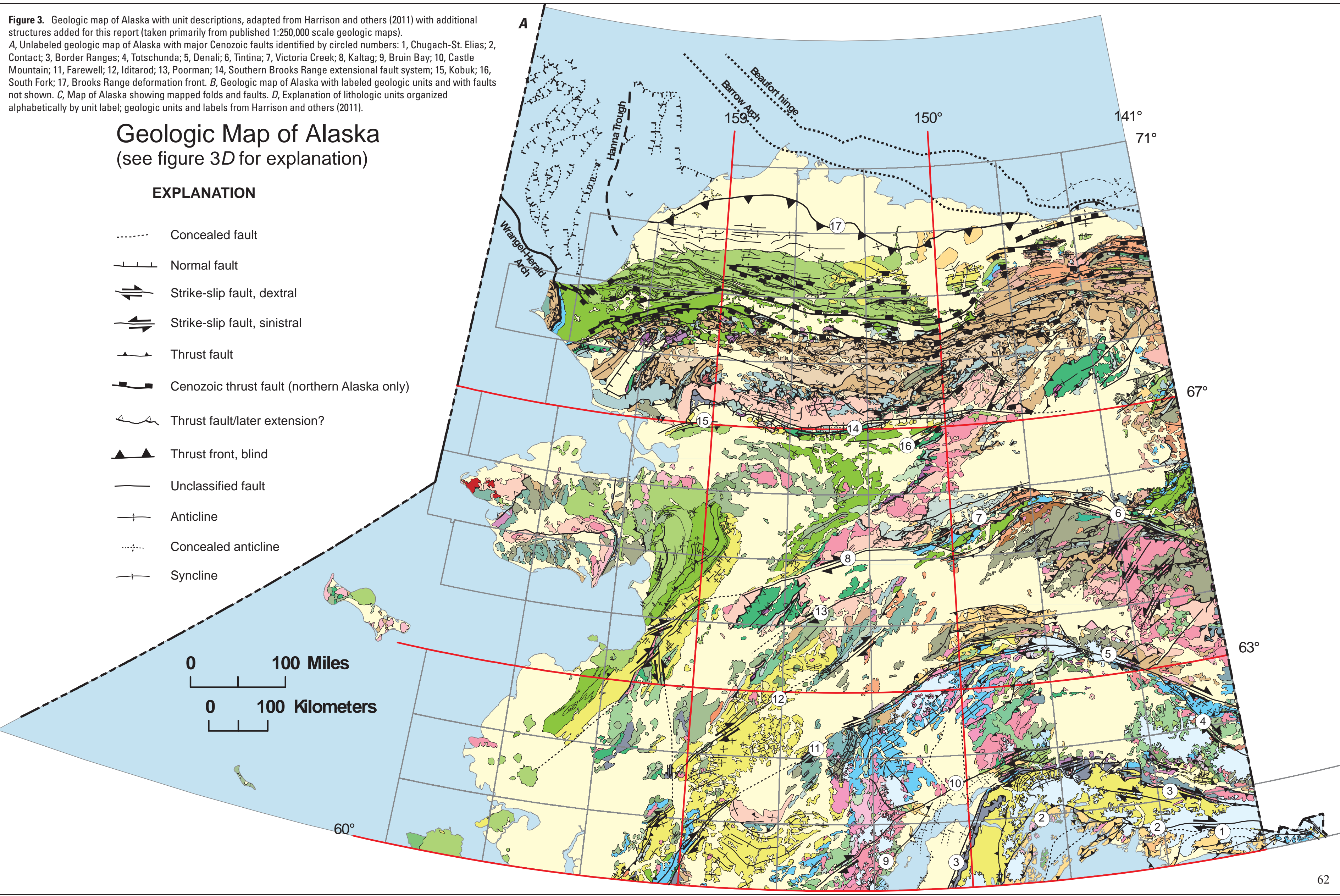




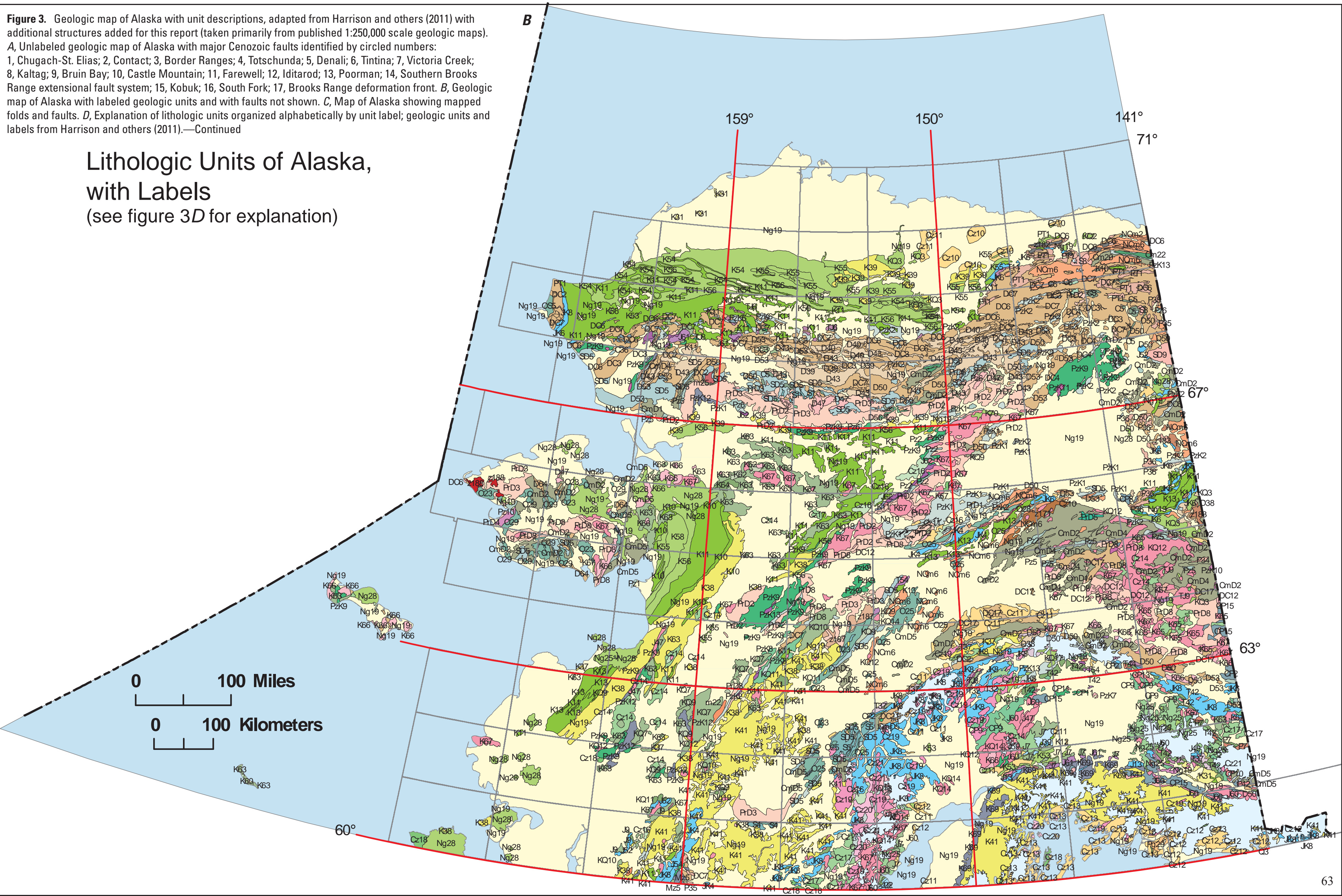




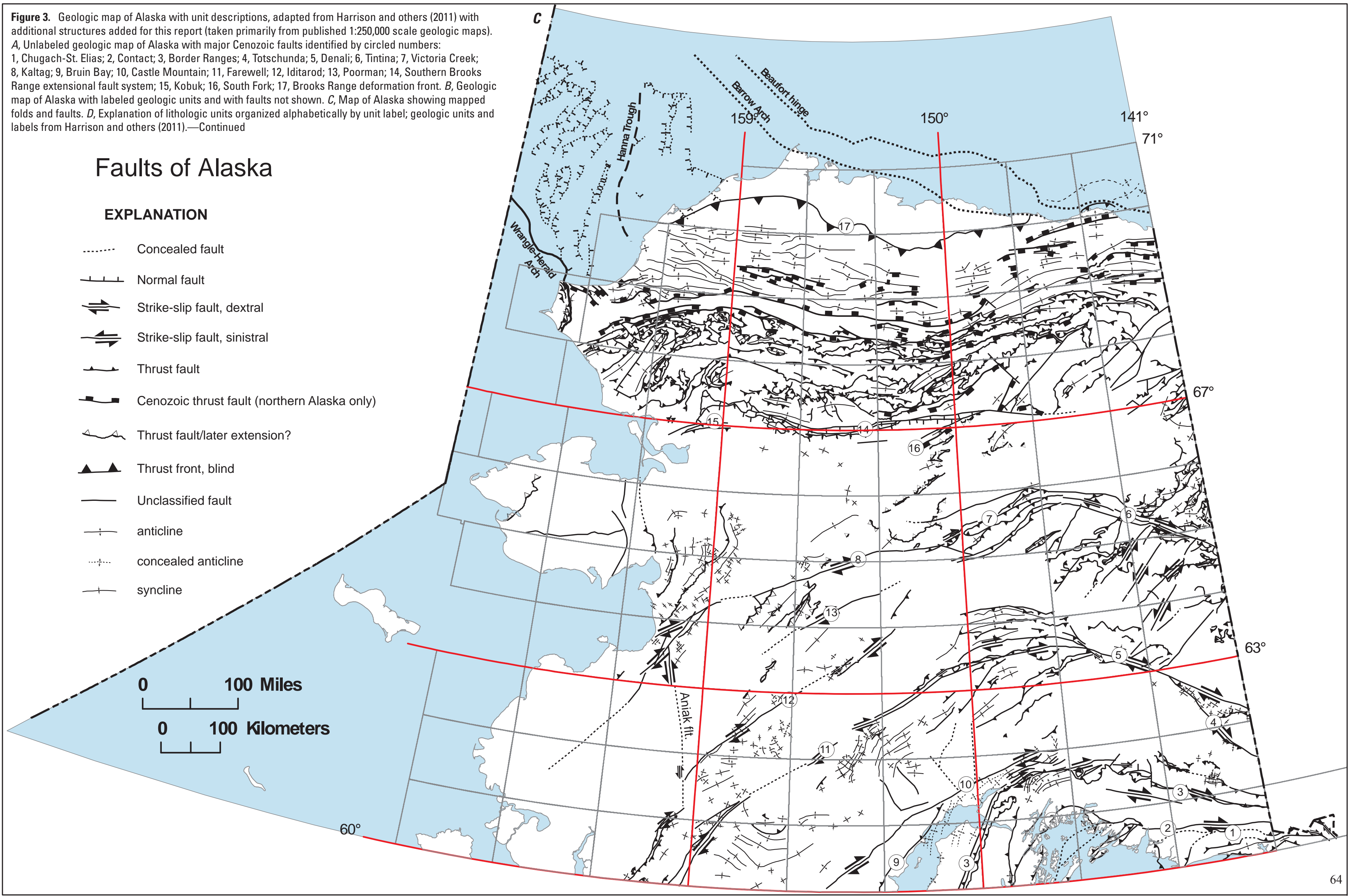




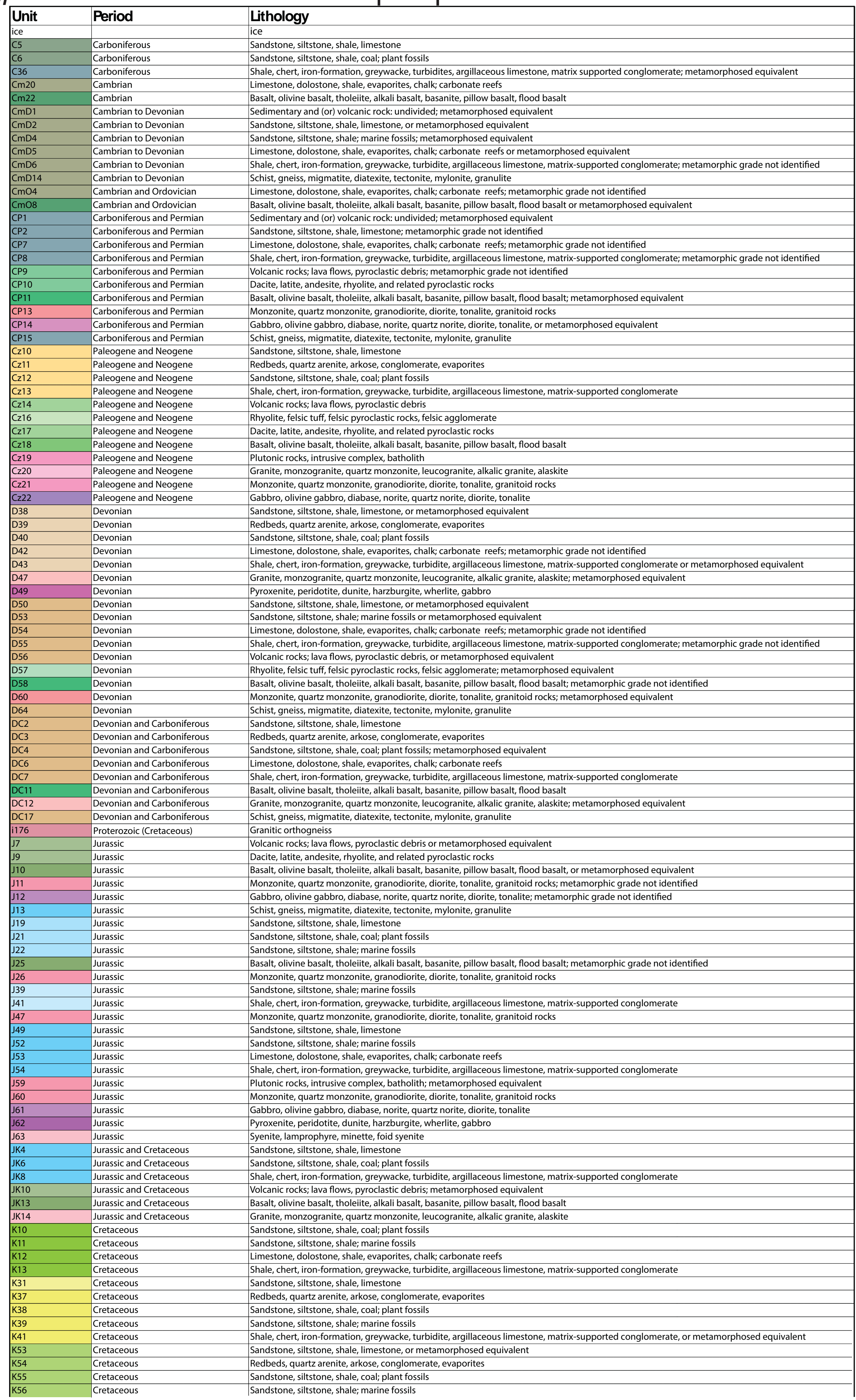


Volcanic rocks; lava flows, pyroclastic debris

Cretaceous

Trachyte, phonolite carbonatitic lava,

Rhyolite, felsic tuff, felsic pyroclastic rocks, felsic agglomerate

Dacite, latite, andesite, rhyolite, and related pyroclastic rocks

Cretaceous

Basalt, olivine basalt, tholeiite, alkali basalt, basanite, pillow basalt, flood basalt

Plutonic rocks, intrusive complex, batholith, or metamorphosed equivalent

Granite, monzogranite, quartz monzonite, leucogranite, alkalic granite, alaskite

Monzonite, quartz monzonite, granodiorite, diorite, tonalite, granitoid rocks

Mélange, polymict breccia, accretionary wedge complex

Schist, gneiss, migmatite, diatexite, tectonite, mylonite, granulite

Sandstone, siltstone, shale, limestone

Cretaceous

Cretaceous and younge

Cretaceous and younger

Cretaceous and younger

Cretaceous and younger

Cretaceous and younger

Cretaceous and younger

Cretaceous and younger

Cretaceous and younge

Cretaceous and younger

Cretaceous and younger

Cretaceous and younger

Cretaceous and younger

Cretaceous and younger

Paleoproterozoic (metamorphic)

Proterozoic (metamorphic)

Mesozoic

Redbeds, quartz arenite, arkose, conglomerate, evaporites

Shale, chert, iron-formation, greywacke, turbidite, argillaceous limestone, matrix-supported conglomerate

Volcanic rocks; lava flows, pyroclastic debris

Rhyolite, felsic tuff, felsic pyroclastic rocks, felsic agglomerate

Dacite, latite, andesite, rhyolite, and related pyroclastic rocks

Basalt, olivine basalt, tholeiite, alkali basalt, basanite, pillow basalt, flood basalt

Plutonic rocks, intrusive complex, batholith

Granite, monzogranite, quartz monzonite, leucogranite, alkalic granite, alaskite

Monzonite, quartz monzonite, granodiorite, diorite, tonalite, granitoid rocks

Gabbro, olivine gabbro, diabase, norite, quartz norite, diorite, tonalite

Mélange, polymict breccia, accretionary wedge complex

Schist, gneiss, migmatite, diatexite, tectonite, mylonite, granulite

Metaplutonic rocks, amphibolite, and minor metasedimentary rocks

Metasedimentary and metavolcanic rocks

Mélange, polymict breccia, accretionary wedge complex

Sandstone, siltstone, shale, limestone; metamorphic grade not identified

Limestone, dolostone, shale, evaporites, chalk; carbonate reefs; metamorphic grade not identified

Shale, chert, iron-formation, greywacke, turbidite, argillaceous limestone, matrix-supported conglomerate or metamorphosed equivalent

Granite, monzogranite, quartz monzonite, leucogranite, alkalic granite, alaskite; metamorphosed equivalent

Sedimentary and (or) volcanic rock: undivided

Volcanic rocks; lava flows, pyroclastic debris

Rhyolite, felsic tuff, felsic pyroclastic rocks, felsic agglomerate

Dacite, latite, andesite, rhyolite, and related pyroclastic rocks

Basalt, olivine basalt, tholeiite, alkali basalt, basanite, pillow basalt, flood basalt

Limestone, dolostone, shale, evaporites, chalk; carbonate reefs or metamorphosed equivalent

Shale, chert, iron-formation, greywacke, turbidite, argillaceous limestone, matrix-supported conglomerate, or metamorphosed equivalent

Trachyte, phonolite, carbonatitic lava, leucitic volcanic rocks

Schist, gneiss, migmatite, diatexite, tectonite, mylonite, granulite

Shale, chert, iron-formation, greywacke, turbidites, argillaceous limestone, matrix supported conglomerate; metamorphosed equivalent Sandstone, siltstone, shale, limestone

Sedimentary and (or) volcanic rock: undivided; metamorphosed equivalent

Sandstone, siltstone, shale, limestone

Redbeds, quartz arenite, arkose, conglomerate, evaporites; metamorphic grade not identified

Monzonite, quartz monzonite, granodiorite, diorite, tonalite, granitoid rocks

Sandstone, siltstone, shale; marine fossils

Sedimentary and (or) volcanic rock: undivided; or metamorphosed equivalent

Sandstone, siltstone, shale, limestone, or metamorphosed equivalent

Limestone, dolostone, shale, evaporites, chalk; carbonate reefs or metamorphosed equivalent

Shale, chert, iron-formation, greywacke, turbidite, argillaceous limestone, matrix-supported conglomerate; metamorphosed equivalent

Basalt, olivine basalt, tholeiite, alkali basalt, basanite, pillow basalt, flood basalt; metamorphosed equivalent

Gabbro, olivine gabbro, diabase, norite, quartz norite, diorite, tonalite

Pyroxenite, peridotite, dunite, harzburgite, wherlite, gabbro, or metamorphosed equivalent

Schist, gneiss, migmatite, diatexite, tectonite, mylonite, granulite

Sandstone, siltstone, shale, limestone

Sedimentary and (or) volcanic rock: undivided; metamorphic grade not identified

Sandstone, siltstone, shale, limestone; metamorphic grade not identified

Sandstone, siltstone, shale; marine fossils; metamorphosed equivalent

Limestone, dolostone, shale, evaporites, chalk; carbonate reefs; metamorphosed equivalent

Shale, chert, iron-formation, greywacke, turbidite, argillaceous limestone, matrix-supported conglomerate: metamorphosed equivalent

Volcanic rocks; lava flows, pyroclastic debris; metamorphic grade not identified

Basalt, olivine basalt, tholeiite, alkali basalt, basanite, pillow basalt, flood basalt; metamorphic grade not identified

Gabbro, olivine gabbro, diabase, norite, quartz norite, diorite, tonalite; metamorphosed equivalent

Pyroxenite, peridotite, dunite, harzburgite, wherlite, gabbro; metamorphic grade not identified

Sedimentary and (or) volcanic rock: undivided; or metamorphosed equivalent

Sandstone, siltstone, shale, limestone, or metamorphosed equivalent

Sandstone, siltstone, shale; marine fossils

Shale, chert, iron-formation, greywacke, turbidite, argillaceous limestone, matrix-supported conglomerate; metamorphic grade not identified

Igneous complex; volcanic and subvolcanic rocks; metamorphosed equivalent

Volcanic rocks; lava flows, pyroclastic debris

Basalt, olivine basalt, tholeiite, alkali basalt, basanite, pillow basalt, flood basalt, or metamorphosed equivalent

Gabbro, olivine gabbro, diabase, norite, quartz norite, diorite, tonalite

Pyroxenite, peridotite, dunite, harzburgite, wherlite, gabbro, or metamorphosed equivalent

Mélange, polymict breccia, accretionary wedge complex; metamorphic grade not identified

Schist, gneiss, migmatite, diatexite, tectonite, mylonite, granulite

Sandstone, siltstone, shale; marine fossils; metamorphic grade not identified

Sandstone, siltstone, shale, limestone; metamorphosed equivalent

Limestone, dolostone, shale, evaporites, chalk; carbonate reefs; metamorphic grade not identified

Shale, chert, iron-formation, greywacke, turbidite, argillaceous limestone, matrix-supported conglomerate; metamorphic grade not identified

Granite, monzogranite, quartz monzonite, leucogranite, alkalic granite, alaskite; metamorphic grade not identified

Limestone, dolostone, shale, evaporites, chalk; carbonate reefs or metamorphosed equivalent

Granite, monzogranite, quartz monzonite, leucogranite, alkalic granite, alaskite; metamorphic grade not identified

Sandstone, siltstone, shale: marine fossils

Sedimentary and (or) volcanic rock: undivided; or metamorphosed equivalent

Limestone, dolostone, shale, evaporites, chalk; carbonate reefs or metamorphosed equivalen

Basalt, olivine basalt, tholeiite, alkali basalt, basanite, pillow basalt, flood basalt or metamorphosed equivalent

Pyroxenite, peridotite, dunite, harzburgite, wherlite, gabbro

Sedimentary and (or) volcanic rock: undivided; metamorphosed equivalent

Gabbro, olivine gabbro, diabase, norite, quartz norite, diorite, tonalite, or metamorphosed equivalent

Redbeds, quartz arenite, arkose, conglomerate, evaporites

Limestone, dolostone, shale, evaporites, chalk; carbonate reefs or metamorphosed equivalent

Shale, chert, iron-formation, greywacke, turbidite, argillaceous limestone, matrix-supported conglomerate; metamorphic grade not identified Volcanic rocks; lava flows, pyroclastic debris; metamorphic grade not identified

Monzonite, quartz monzonite, granodiorite, diorite, tonalite, granitoid rocks

Gabbro, olivine gabbro, diabase, norite, quartz norite, diorite, tonalite

Triassic and Jurassic

Neoproterozoic (sedimentary)

Proterozoic (sedimentary)

roterozoic (sedimentary)

roterozoic (sedimentary)

Proterozoic (sedimentary)

Calcareous sandstone, shale, quartz-eye grit, quartzite, micaceous quartzite, and minor limestone

Dolostone, silty dolostone, chert, stromatolitic

Quartzite and quartz-rich sandstone

Pelitic schist, paragneiss

Graphitic siltite, slate, graywacke, calcareous siltite

Figure 3. Geologic map of Alaska with unit descriptions, adapted from Harrison and others (2011) with additional structures added for this report (taken primarily from published 1:250,000 scale geologic maps). A Unlabeled geologic map of Alaska with major Cenozoic faults identified by circled numbers:

1, Chugach-St. Elias; 2, Contact; 3, Border Ranges; 4, Totschunda; 5, Denali; 6, Tintina; 7, Victoria Creek;

8, Kaltag; 9, Bruin Bay; 10, Castle Mountain; 11, Farewell; 12, Iditarod; 13, Poorman; 14, Southern Brooks Range extensional fault system; 15, Kobuk; 16, South Fork; 17,

Brooks Range deformation front. B, Geologic map of Alaska with labeled geologic units and with faults not shown. C, Map of Alaska showing mapped folds and faults. $D$,

Explanation of lithologic units organized alphabetically by unit label; geologic units and labels from Harrison and others (2011).-Continued 
Figure 4. Tectonostratigraphic terrane map of Alaska, generalized from Silberling and others (1992) by combining similar and related terranes (see text for details). Revised terranes include Arctic Alaska (AA),

Angayucham-Tozitna-Innoko (ATI), Farewell (FW), Livengood (LG)

McKinley-Windy (MK), and Wickersham-White Mountains (WW) terranes;

Yukon-Tanana subdivided into allochthonous Yukon-Tanana (YTa), Chatanika

klippe (YTc), and parautochthonous Yukon-Tanana (YTp). Abbreviations for othe terranes are $\mathrm{AX}$, Alexander; $\mathrm{BP}$, Broad Pass; $\mathrm{CG}$, Chugach; $\mathrm{CH}$, Chulitna; GD, Goodnews; KIL, Kilbuck; KY, Koyukuk; LG, Livengood; MN, Minchumina; MNK, Minook: NAm, cratonal North America; NY, Nyak; PC, Porcupine; PE, Peninsular PN, Pingston: PW, Prince William: RB, Ruby; SU, Susitna; SV Seventymile: TG Togiak: TK, The hik; WF, West Fork; WR, Wrangellia; YA, Yakutat Major Cenoz,

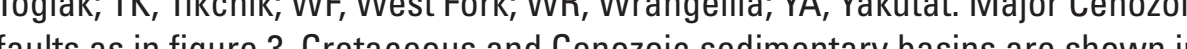

white.

\section{Simplified Terrane Map}

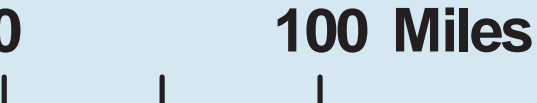

$0 \quad 100$ Kilometers

100 Miles

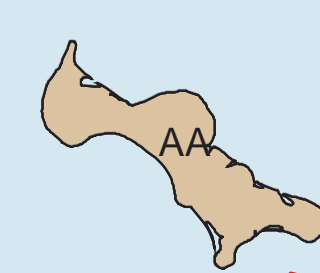
,

AA
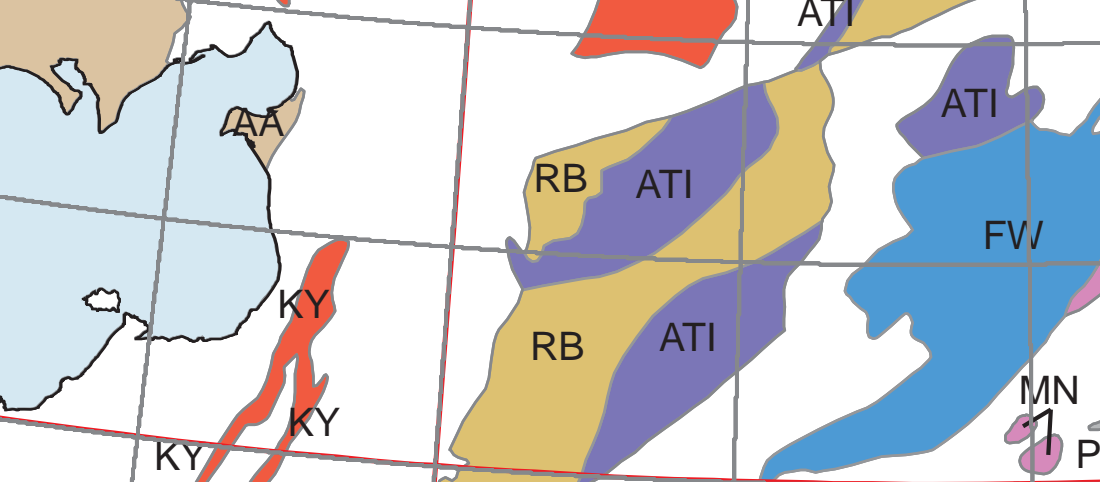

.

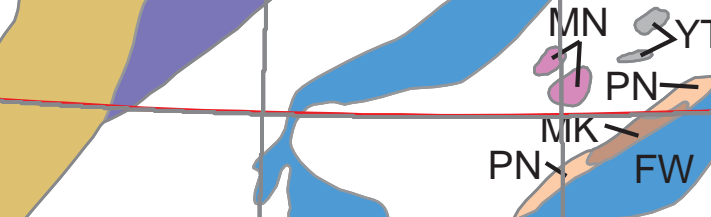
$\mathrm{PN} \times \mathrm{MW}$
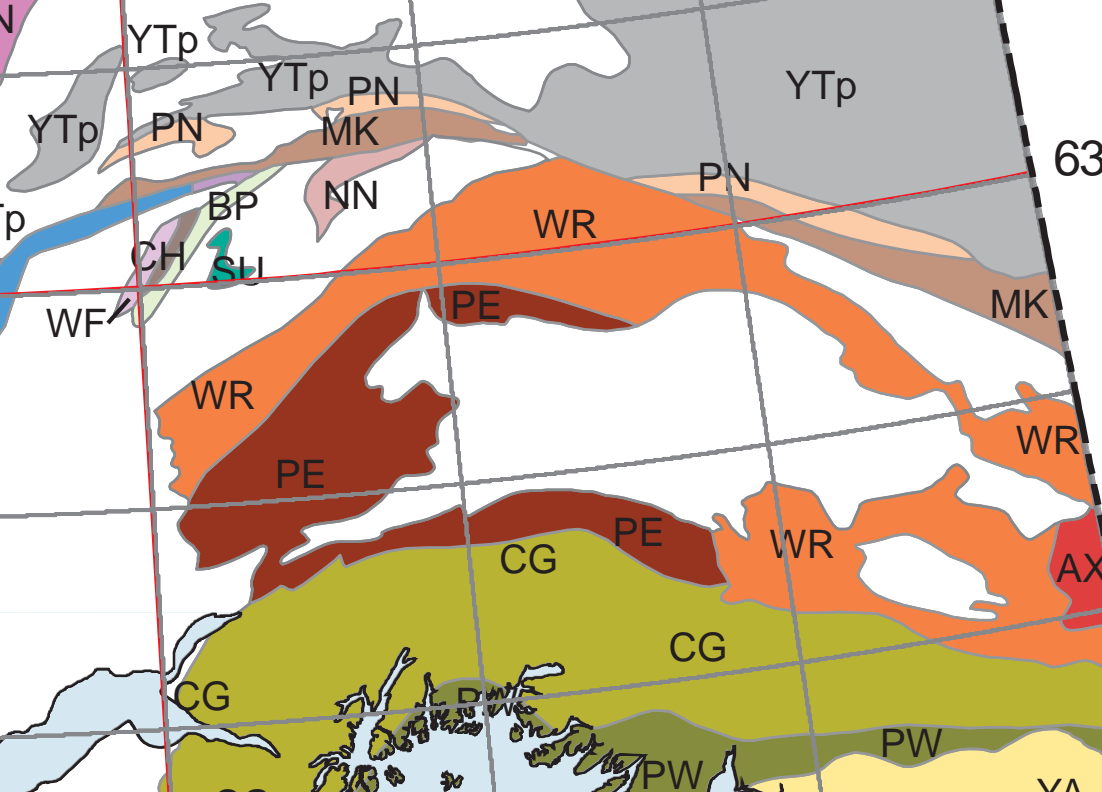

$\mathrm{YTa}$ 


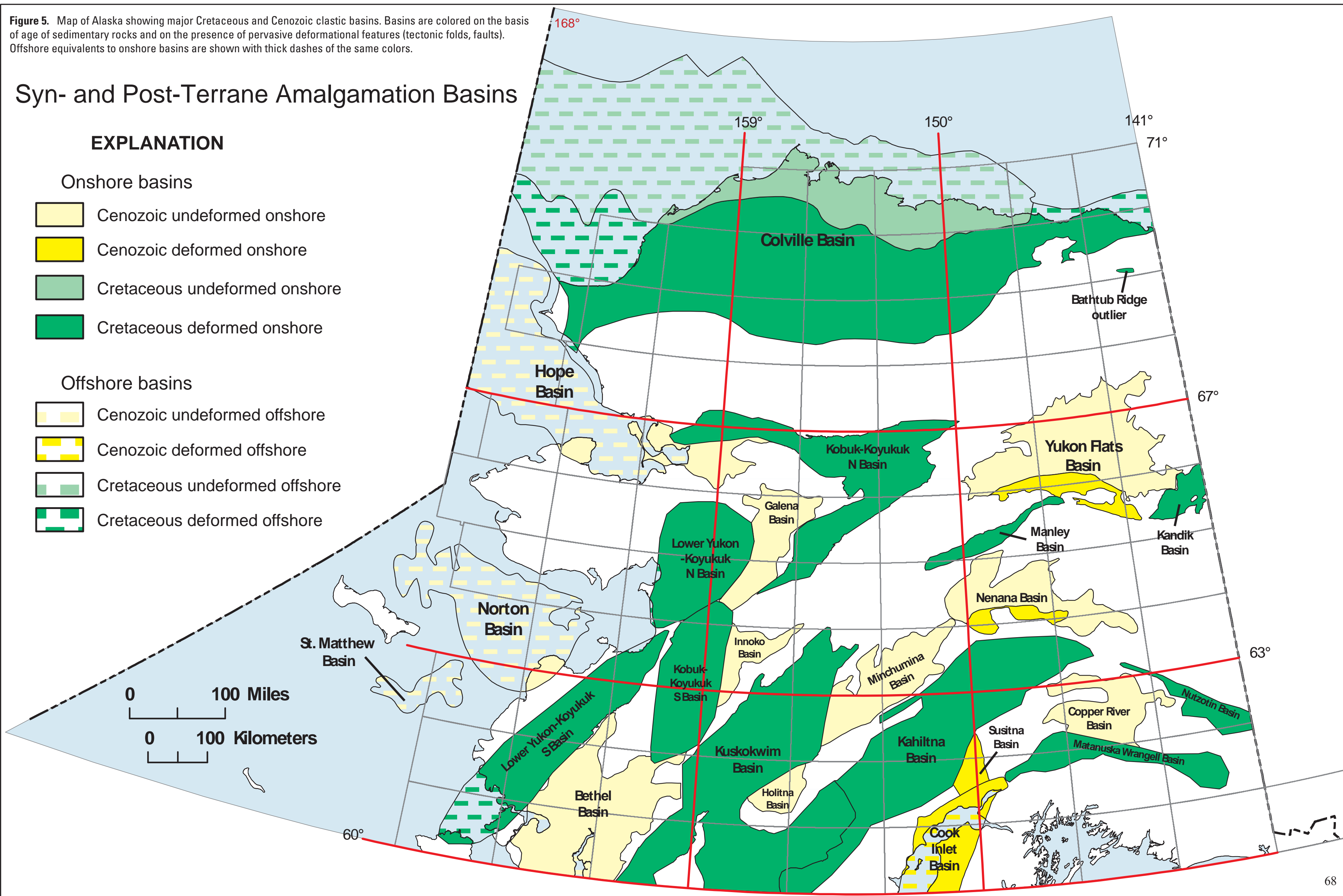


Figure 6. Map of Alaska showing distribution of ophiolitic sections of mafic and

utramafic intrusive rocks, of accretionary assemblages composed primarily of basat

and interleaved chert, of accretionary assemblages composed primarily of clas

nonmarine) deposited in a foreland basin setting. As used in this paper, the combined

Angayucham-Tozitina-Innoko terrane consists of basalt-chert accretionary

assemblages and ophiolite units in NW, NC, NE, C, and northern EC (north of

Tintina-Victoria Creek Faults) quadrants (red lines; see figure 2 for locations).

Numbers indicate locations of ophiolitic klippen (Patton and others, 1994c): 1, lyikrok

Mountain; 2, Asik Mountain; 3, Avan Hills; 4, Misheguk Mountain; 5, Siniktanneyak

Mountain; 6, Jade Mountains; 7, Christian; 8, Pitka; 9, Kanuti; 10, Yuki; 11, Mount

Hurst-Disha; 12, American Eagle; 13, Mount Sorenson; 14, Salcha River; 15, Border

Ranges ultramafic and mafic assemblage (BRUMA).

\section{Selected Tectonically Important Lithologic Assemblages}

\section{EXPLANATION}

Ophiolite

Basalt-chert accretionary assemblages

Sedimentary accretionary assemblages

Molasse

100 Miles

0

100 Klometers

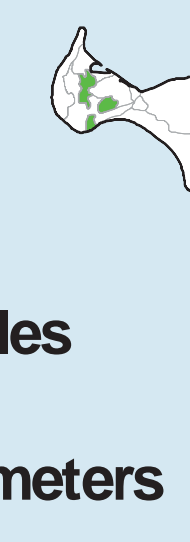

$60^{\circ}$

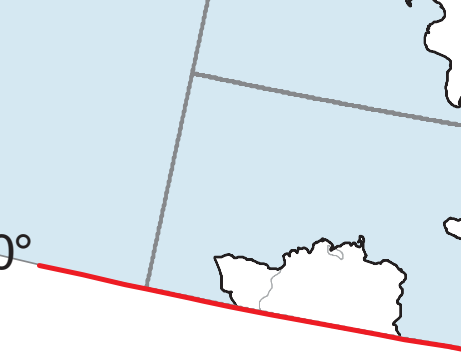

(
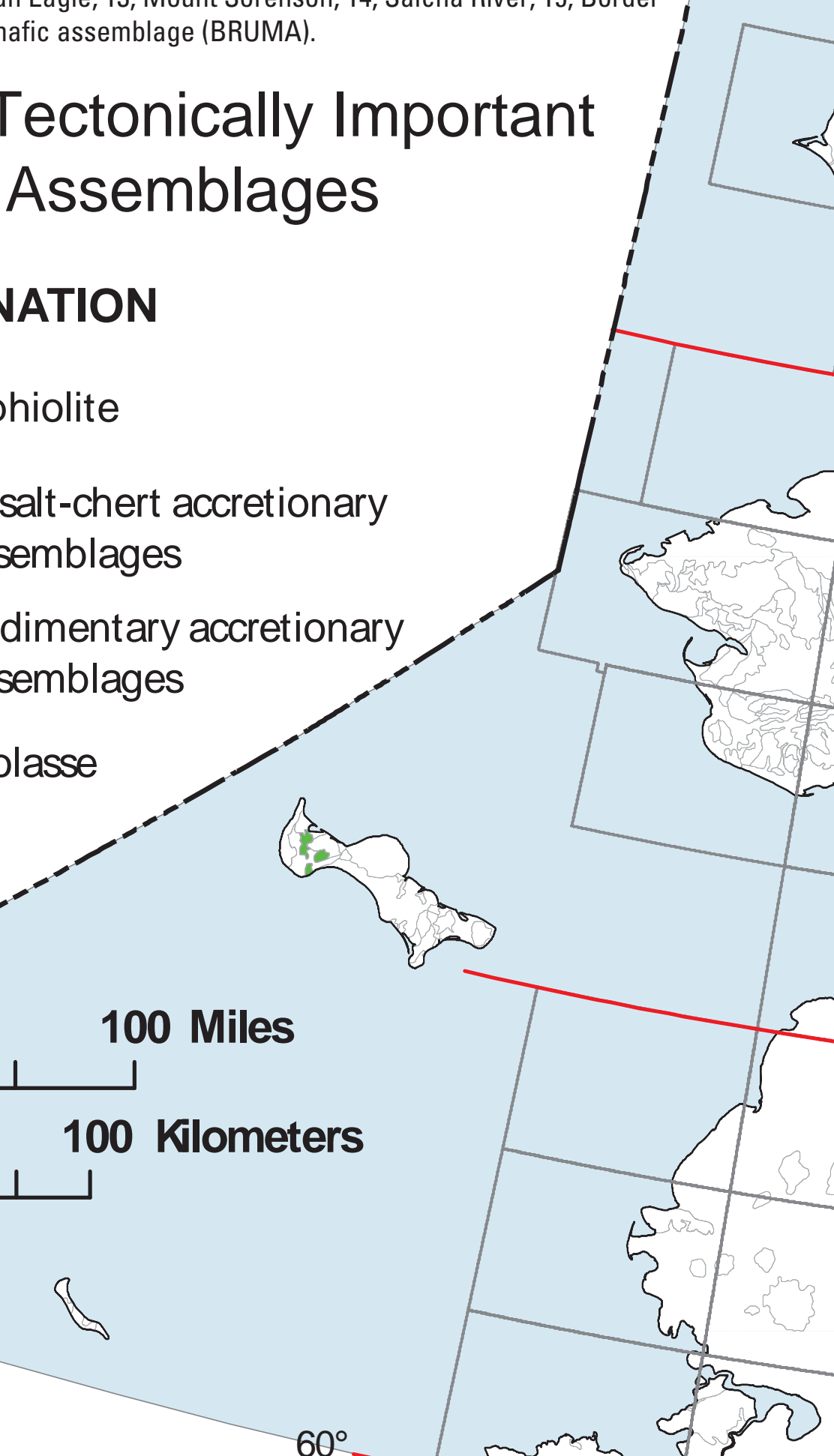
Figure 8. Maps showing distribution of areas in Alaska affected by $\mathrm{P} 1$

deformation (2.5-1.6 Ga, Paleoproterozoic). A, Distribution of geologic map

units (Harrison and others, 2011) affected by P1 deformation; unaffected unit

polygons shown in outline. $B$, Generalized P1 deformation areas colored by

deformational style; base map shows terranes with major Cenozoic faults

(from figure 4). Mtns., Mountains; ter., terrane.

\section{Map Units Affected by}

P1 (2.5-1.6 Ga) Deformation

EXPLANATION

P1 deformation

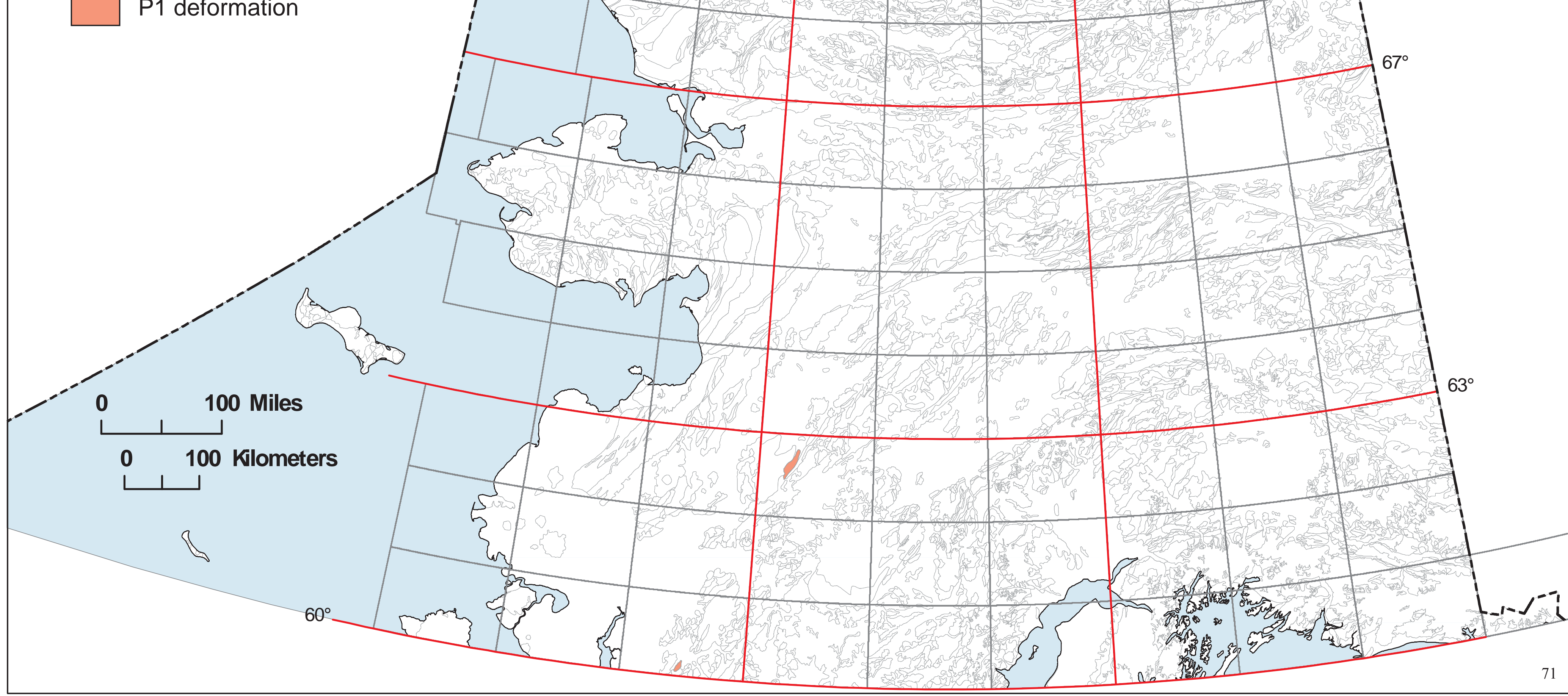


Figure 8. Maps showing distribution of areas in Alaska affected by P1

deformation (2.5-1.6 Ga, Paleoproterozoic). A, Distribution of geologic map

units (Harrison and others, 2011) affected by P1 deformation; unaffected unit

polygons shown in outline. $B$, Generalized P1 deformation areas colored by

deformational style; base map shows terranes with major Cenozoic faults

(from figure 4). Mtns., Mountains; ter., terrane.-Continued

\section{P1 (2.5-1.6 Ga) Structural}

Styles and Kinematics

\section{EXPLANATION}

DEFORMATIONAL STYLE

Penetrative contractional style

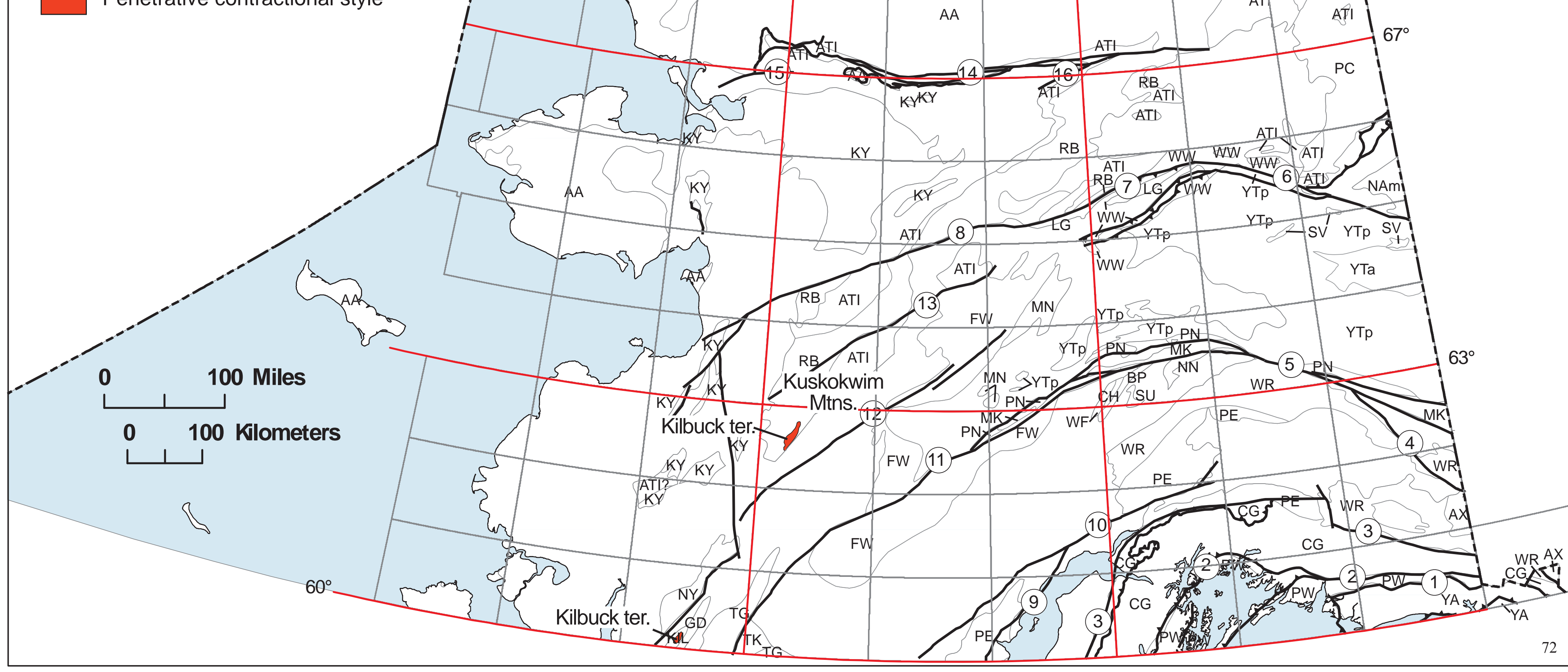




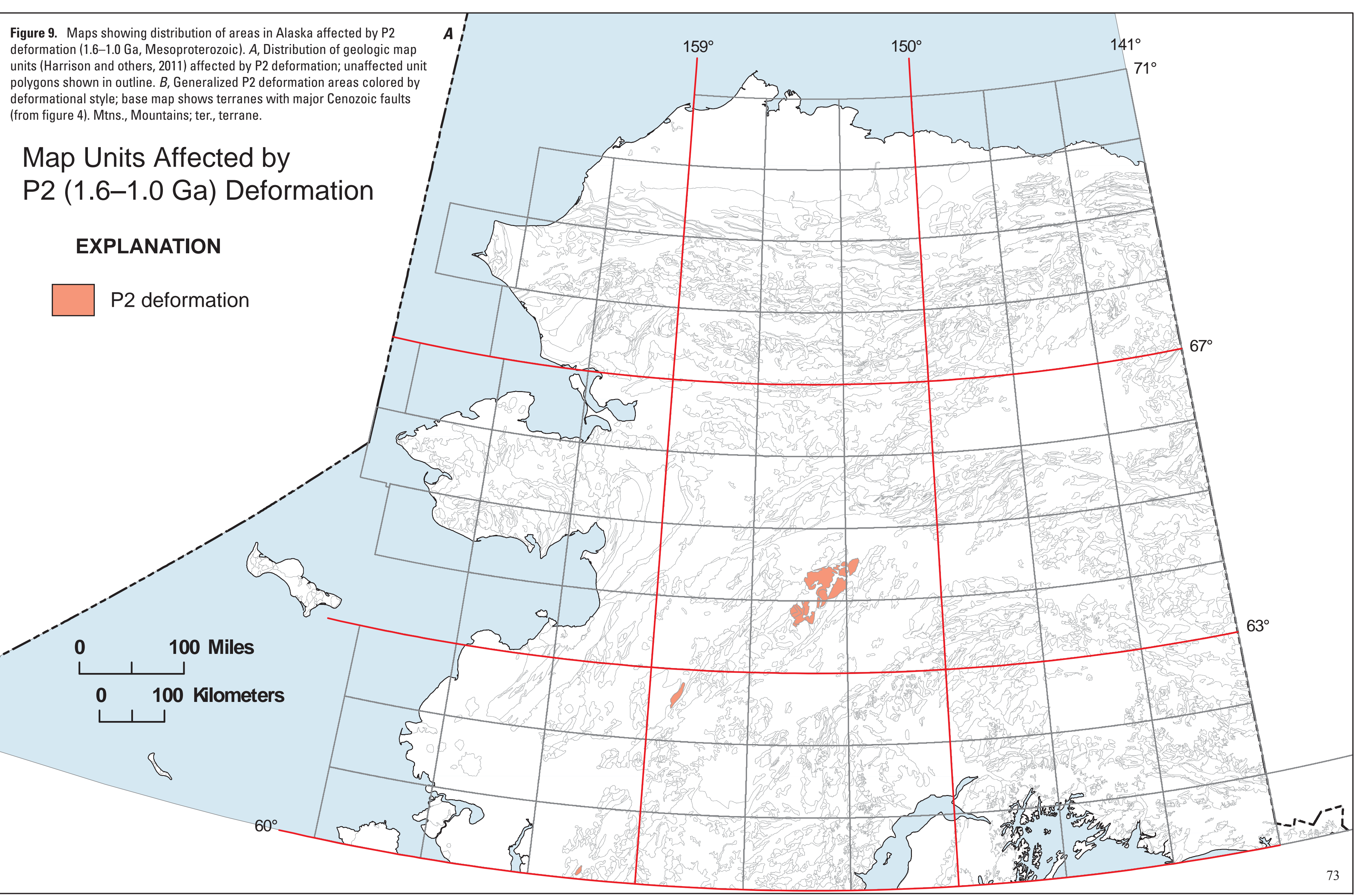




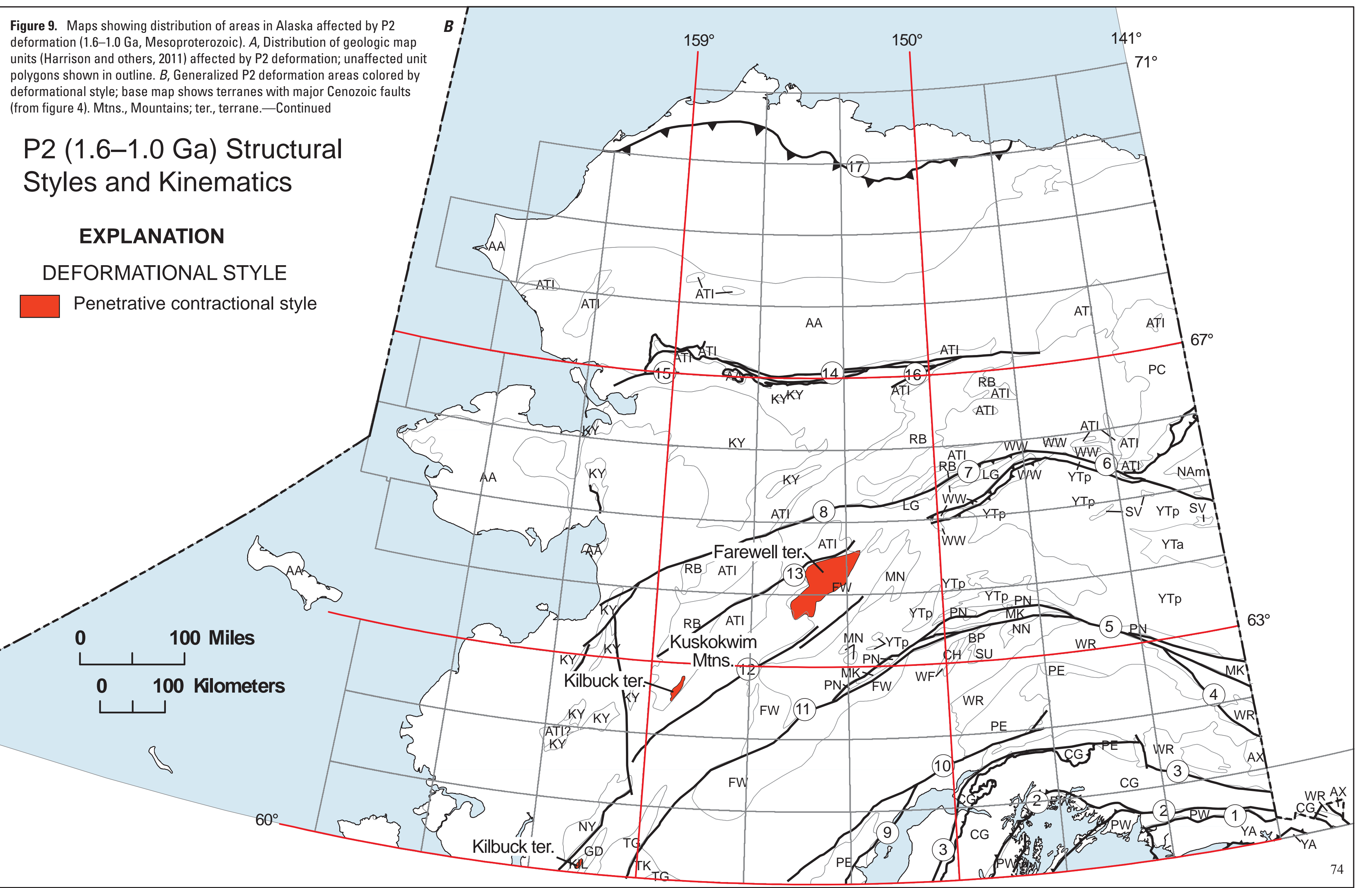




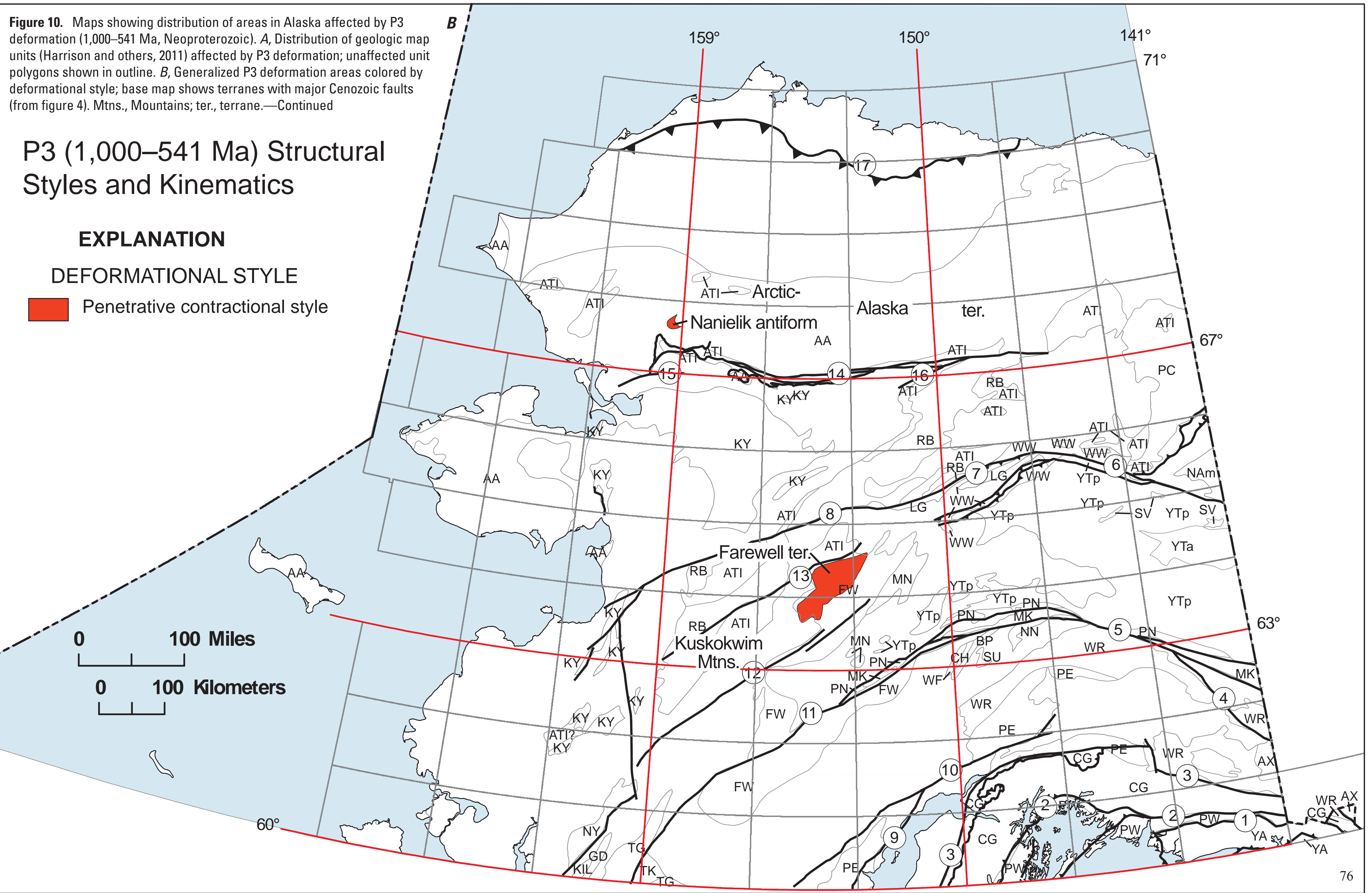




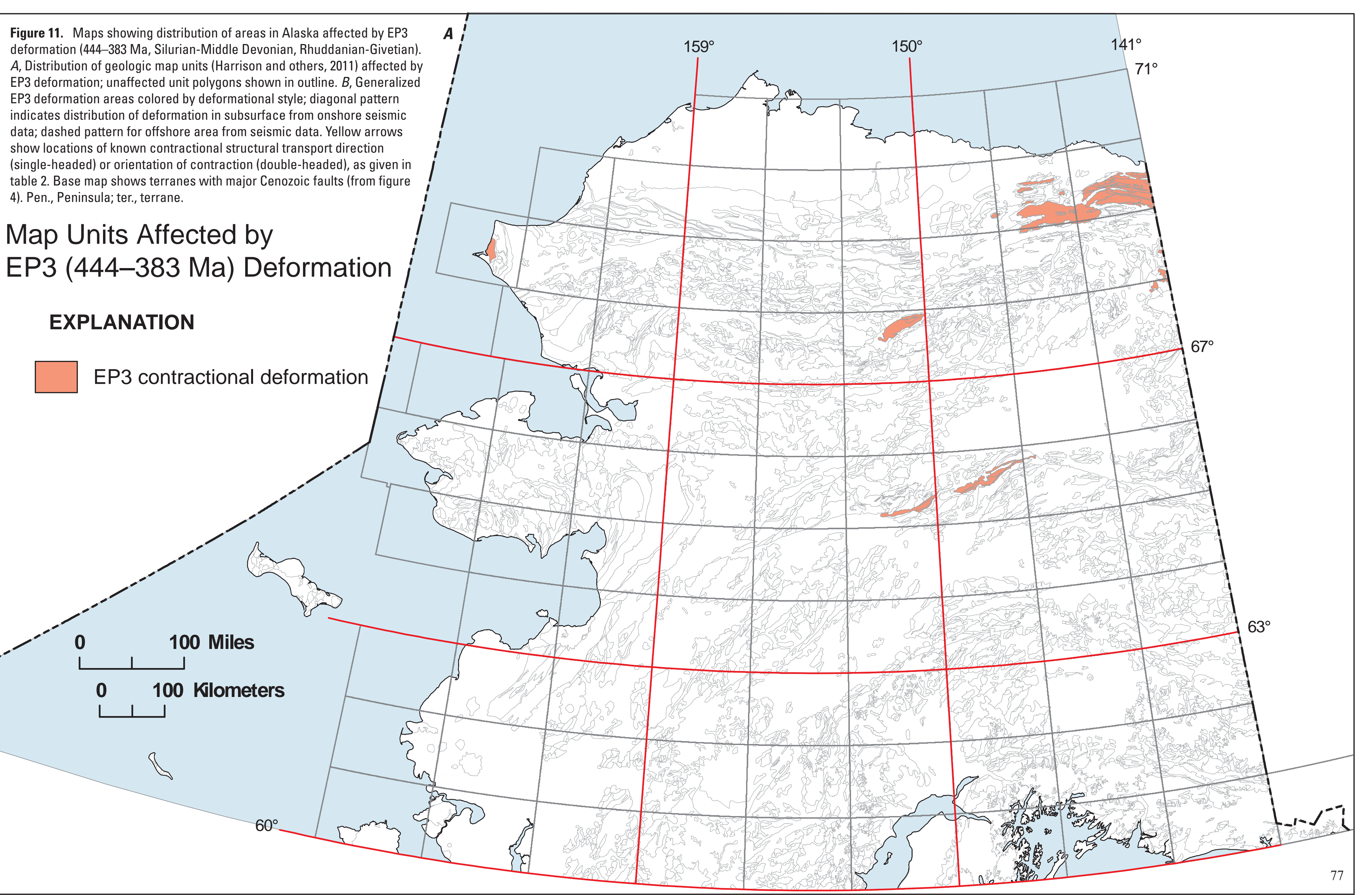


Figure 12. Maps showing distribution of areas in Alaska affected by LP3 deformation (323-299 Ma, Pennsylvanian). A, Distribution of geologic map units (Harrison and others, 2011) affected by LP3 deformation; unaffected

unit polygons shown in outline. $B$, Generalized LP3 deformation areas

colored by deformational style. Base map shows terranes with major

Cenozoic faults (from figure 4). ter., terrane.

\section{Map Units Affected by}

LP3 (323-299 Ma) Deformation

\section{EXPLANATION}

LP3 deformation

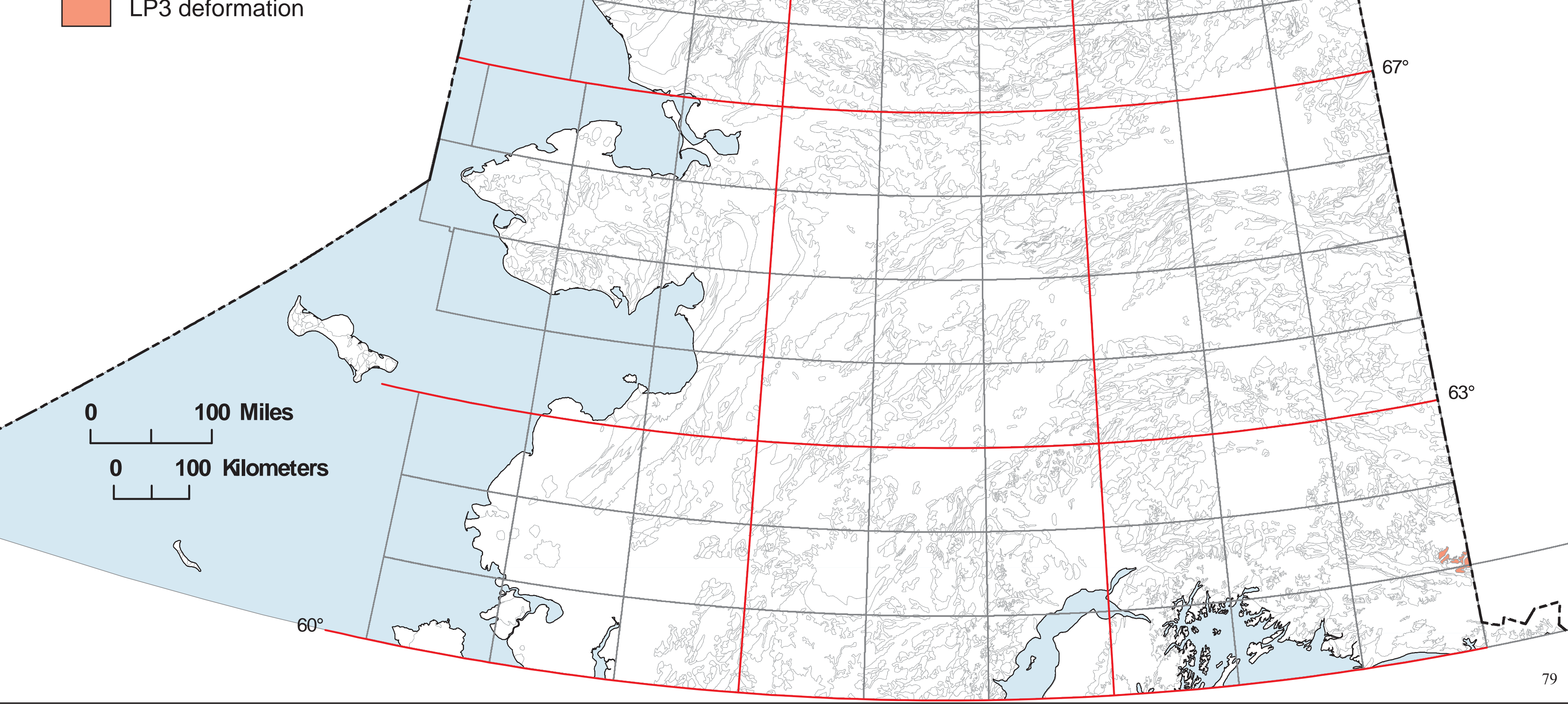




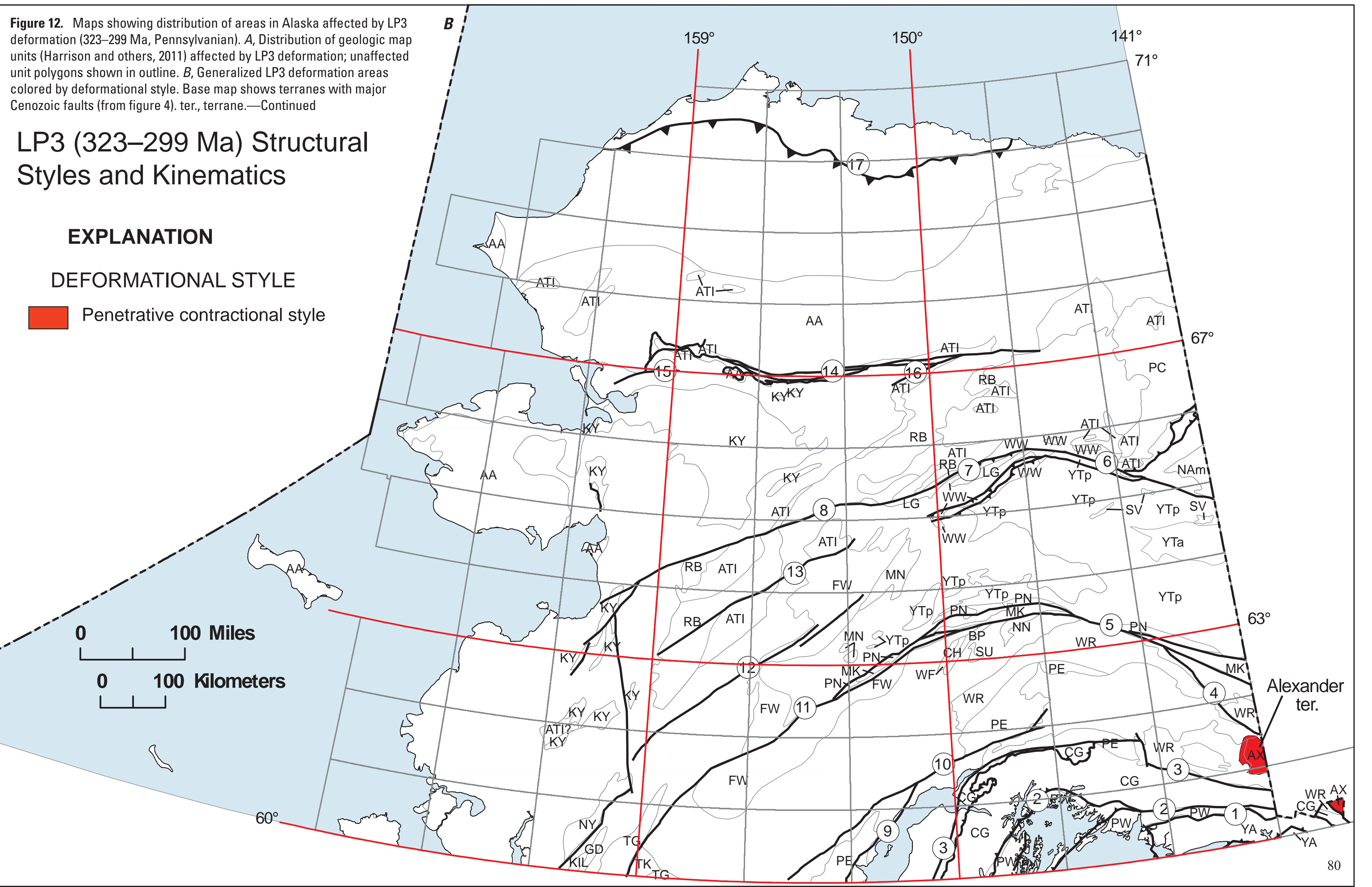


Figure 13. Maps showing distribution of areas in Alaska affected by LP4 deformation (299-252 Ma, Permian). A, Distribution of geologic map units

(Harrison and others, 2011) affected by LP4 deformation; unaffected unit

polygons shown in outline. $B$, Generalized LP4 deformation areas colored

by deformational style. Yellow numbered arrows (keyed to table 2) show

locations of known contractional structural transport direction

(single-headed) or orientation of contraction (double-headed). Base map

shows terranes with major Cenozoic faults (from figure 4). ter, terrane.

\section{Map Units Affected by}

LP4 (299-252 Ma) Deformation

\section{EXPLANATION}

LP4 contractional deformation

\section{$0 \quad 100$ Miles}

0

100 Kilometers

L 1

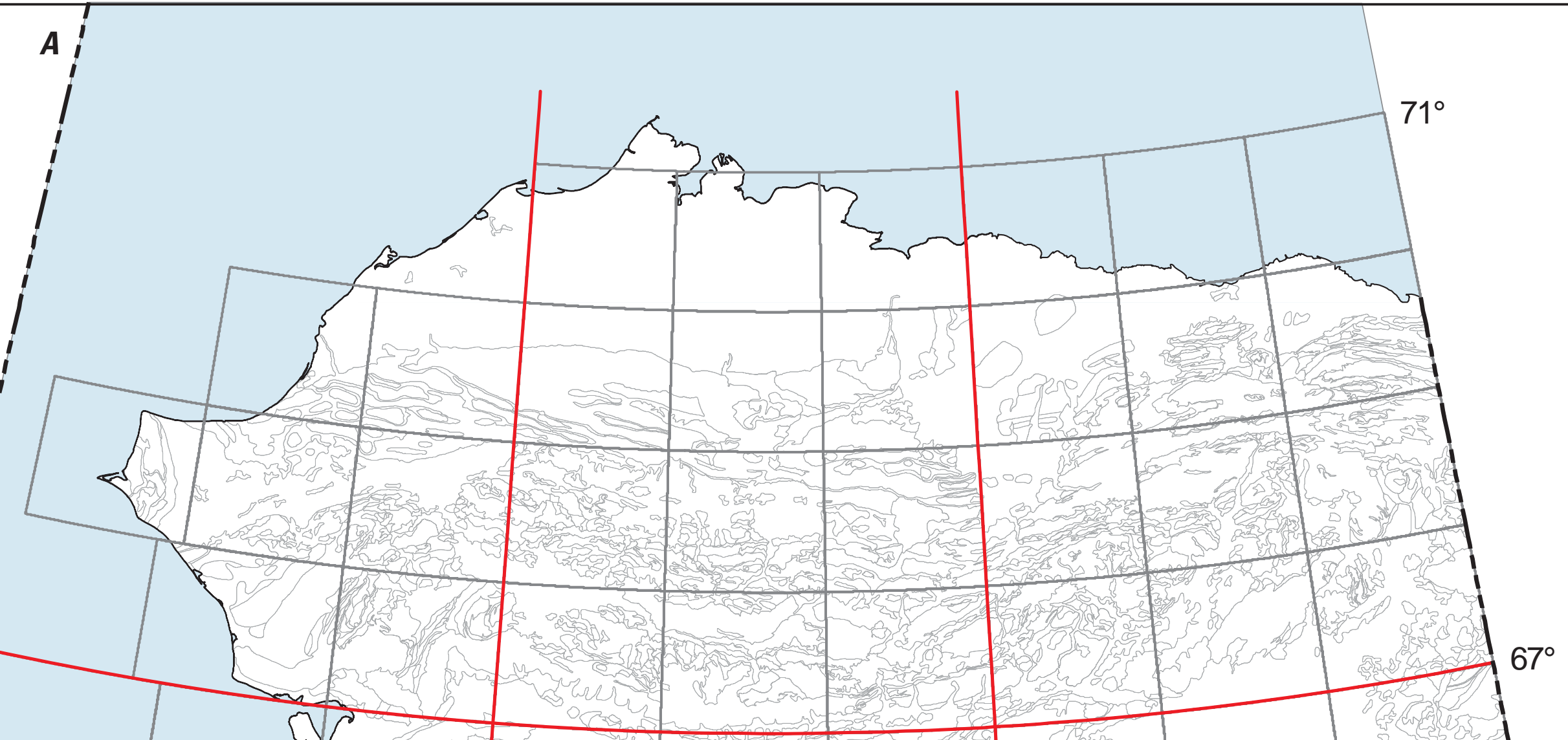

remeters

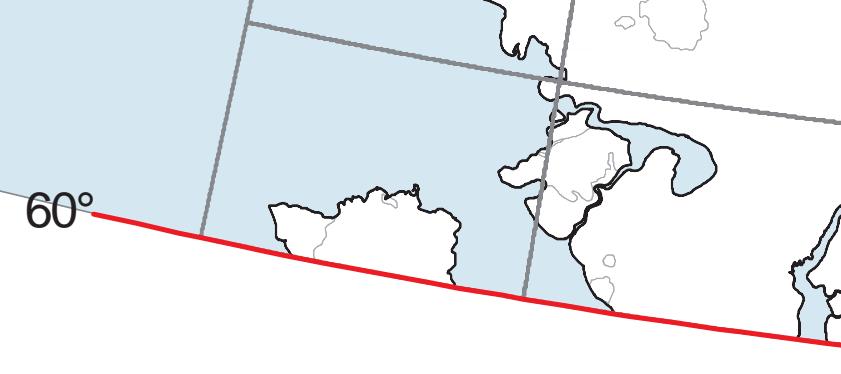




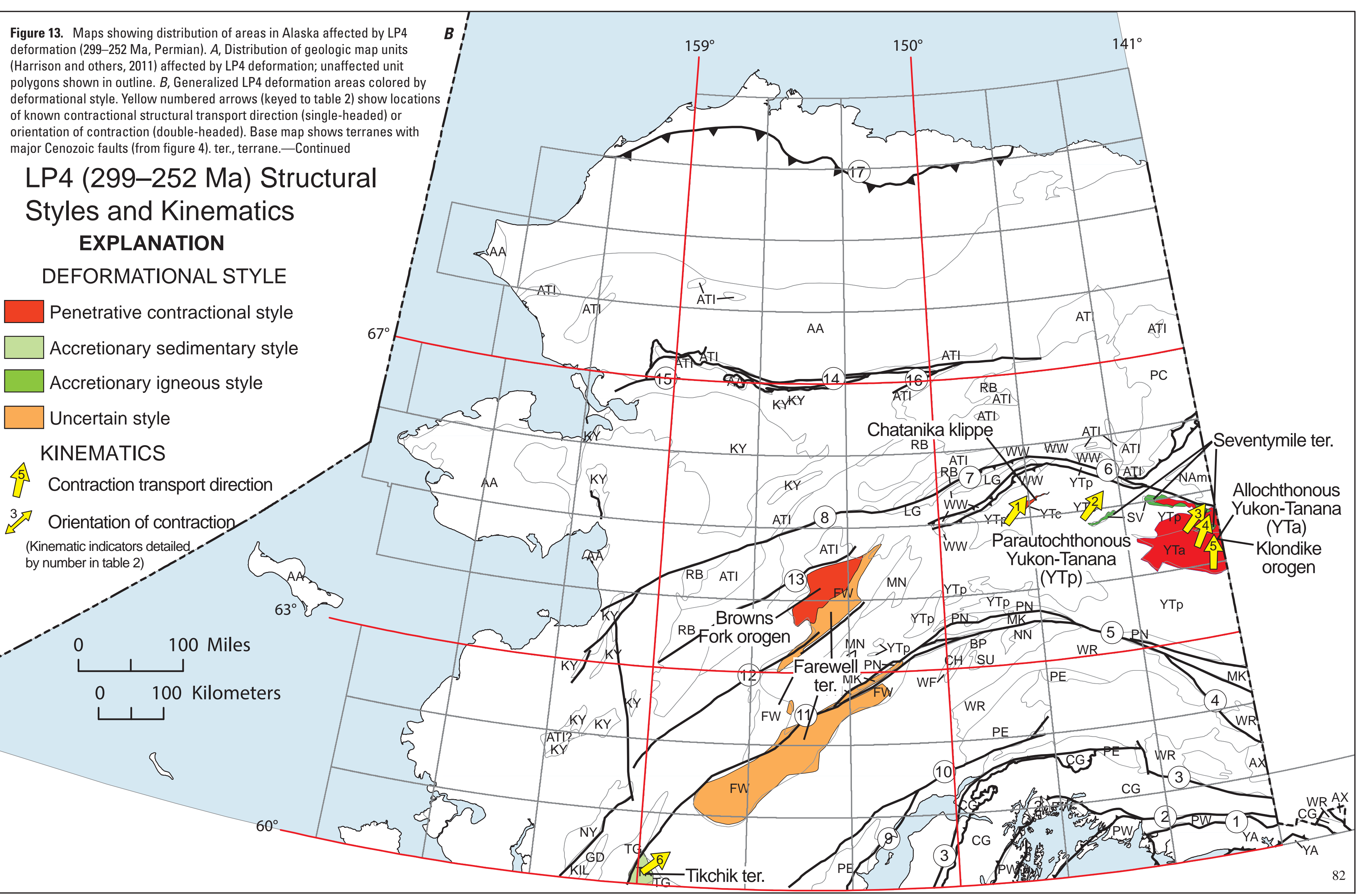


Figure 14. Maps showing distribution of areas in Alaska affected by EM2 deformation (201-170 Ma, Early Jurassic, Hettangian-Aalenian). A,

Distribution of geologic map units (Harrison and others, 2011) affected by

EM2 deformation; unaffected unit polygons shown in outline. $B$, Generalized

EM2 deformation areas colored by deformational style. Yellow numbered

arrows (keyed to table 2) show locations of known contractional structura

transport direction (single-headed) or orientation of contraction

(double-headed). Base map shows terranes with major Cenozoic faults

(from figure 4).

\section{Map Units Affected by}

EM2 (201-170 Ma) Deformation

\section{EXPLANATION}

EM2 contractional deformation

\section{$0 \quad 100$ Miles}

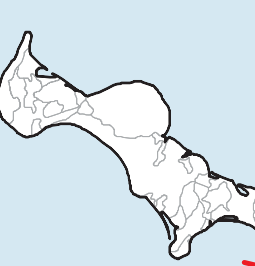

0

100 Kilometers
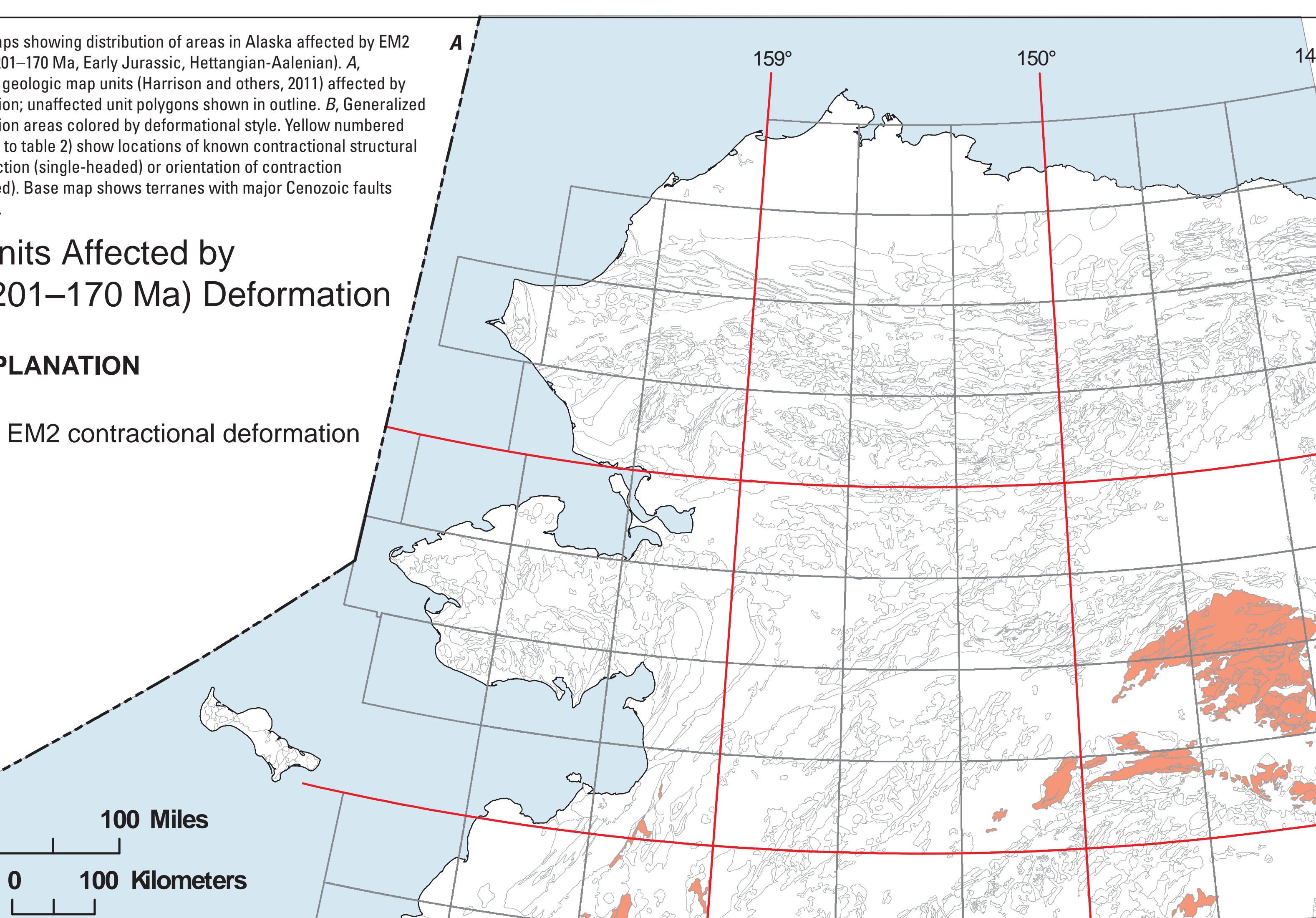


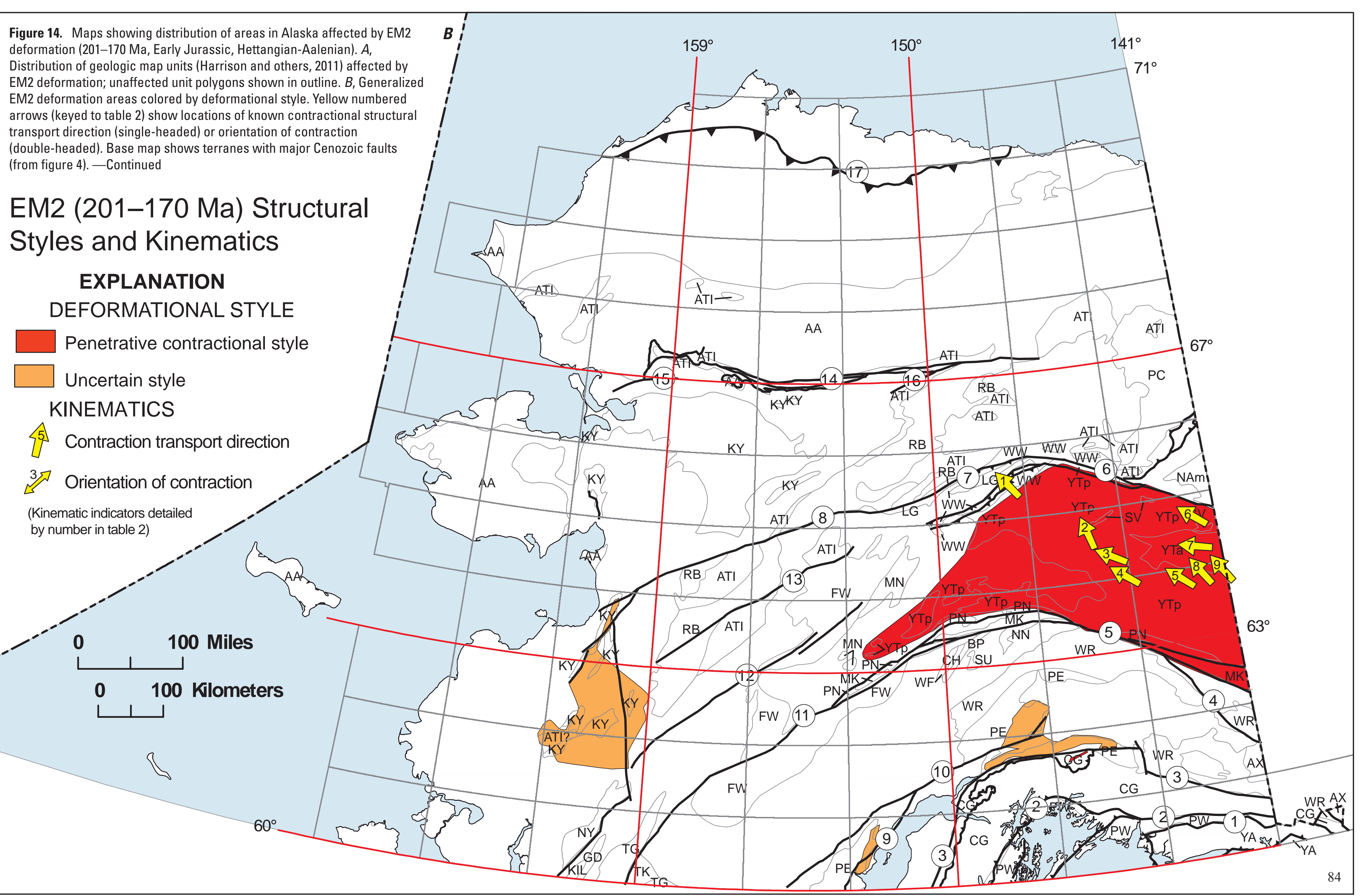


Figure 15. Maps showing distribution of areas in Alaska affected by EM3 deformation (170-145 Ma, Middle and Late Jurassic, Bajocian-Tithonian). $A$

Distribution of geologic map units (Harrison and others, 2011) affected by

EM3 deformation; unaffected unit polygons shown in outline. $B$, Generalized

EM3 deformation areas colored by deformational style. Yellow numbered

arrows (keyed to table 2) show locations of known contractional structura

transport direction (single-headed) or orientation of contraction

(double-headed). Base map shows terranes with major Cenozoic faults

(from figure 4) assemb, assemblage; cplx, complex; flt fault; metam,

metamorphic; Mtns., Mountains; Rv., River; seq, sequence; ter., terrane.

\section{Map Units Affected by}

EM3 (170-145 Ma) Deformation

\section{EXPLANATION}

EM3 contractional deformation

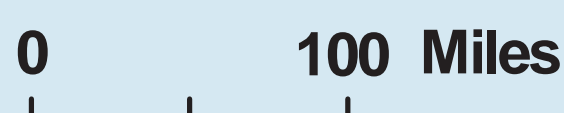

0

100 Kilometers

L ل 


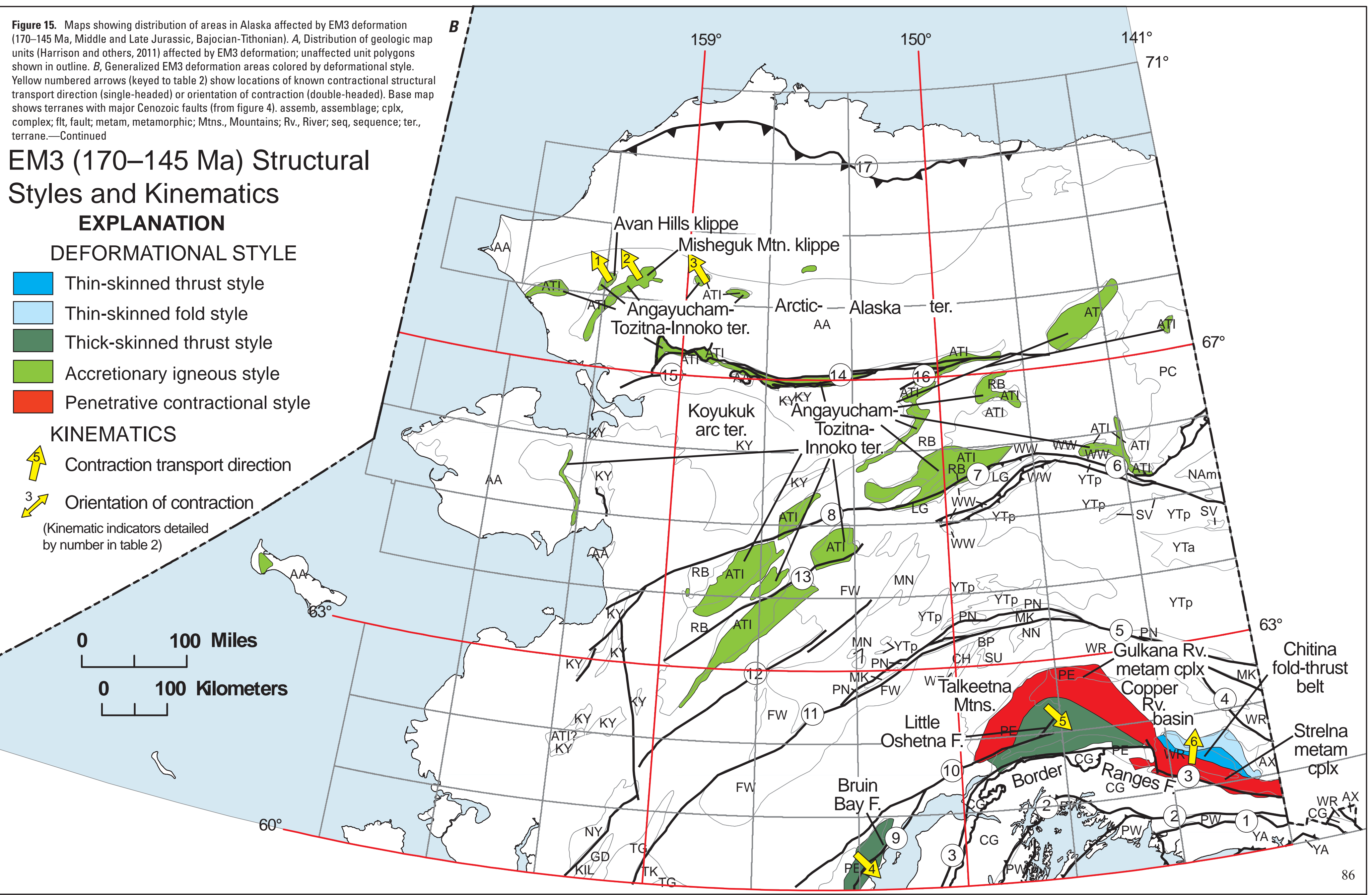


Figure 16. Maps showing distribution of areas in Alaska affected by LM1 deformation (145-113 Ma, early Early Cretaceous, Berriasian-Aptian). $A_{\text {, }}$

Distribution of geologic map units (Harrison and others, 2011) affected by

LM1 deformation; unaffected unit polygons shown in outline. $B$, Generalized

LM1 deformation areas colored by deformational style. Yellow numbered

arrows (keyed to table 2) show locations of known contractional structura

transport direction (single-headed) or orientation of contraction

(double-headed). Base map shows terranes with major Cenozoic faults

(from figure 4). Am America; Ck, Creek; metam, metamorphic; Mtns,

Mountains; Pen. Peninsula; Rv., River; ter., terrane.

\section{Map Units Affected by}

LM1 (145-113 Ma) Deformation

\section{EXPLANATION}

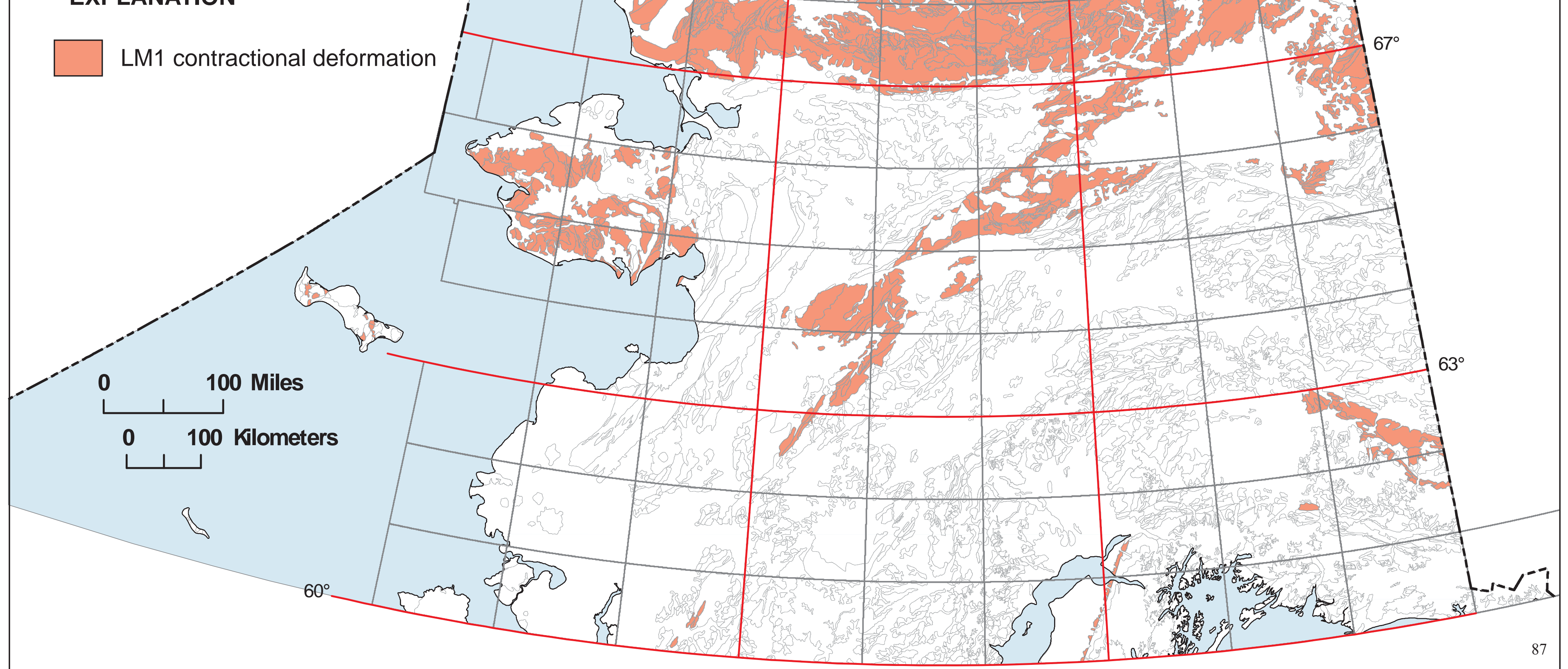




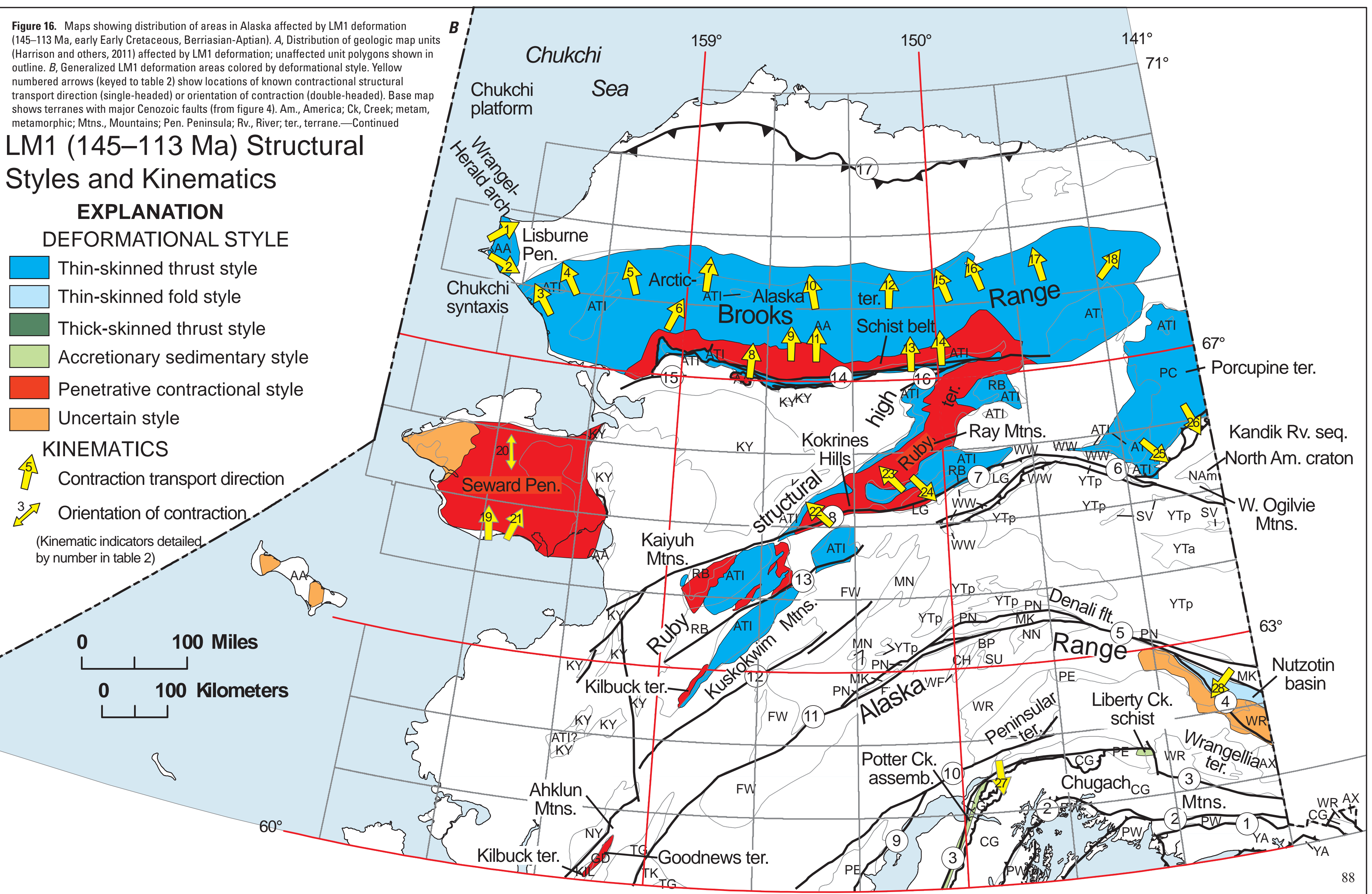


Figure 17. Maps showing distribution of areas in Alaska affected by LM2c (compressive) deformation (113-86 Ma, late Early-early Late Cretaceous, Albian-Coniacian). $A$, Distribution of geologic map units

(Harrison and others, 2011) affected by LM2c deformation; unaffected

unit polygons shown in outline. $B$, Generalized LM2c deformation areas colored by deformational style. Yellow numbered arrows (keyed to table 2) show locations of known contractional structural transport direction (single-headed) or orientation of contraction (double-headed). Base map shows terranes with major Cenozoic faults (from figure 4). antif, antiform; assemb, assemblage; F., Fault; Mtns., Mountains; Pks, Peaks;

Rv., River; ter., terrane. Note that the areas of distribution and

deformational style of LM2C deformation in the western Olgilvie

Mountains, and adjacent areas and in the Livengood,

Wickersham-White Mountains, and Minchumina terranes, were

inadvertently omitted from figure 13 of Moore and Box (2016) but are shown correctly here in figure $17 B$.

\section{Map Units Affected by}

LM2c (113-86 Ma) Deformation EXPLANATION

LM2C contractional deformation

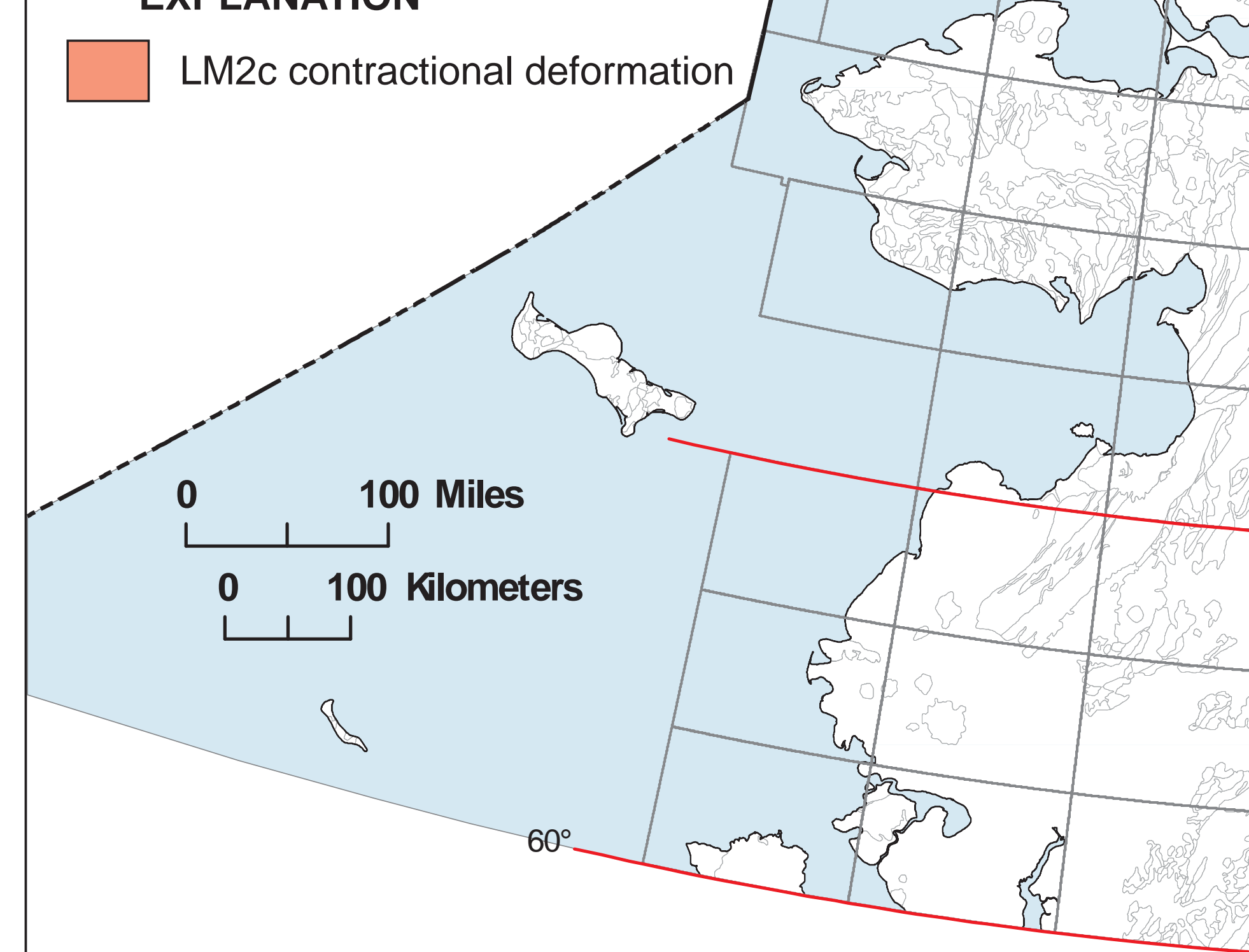

(1)

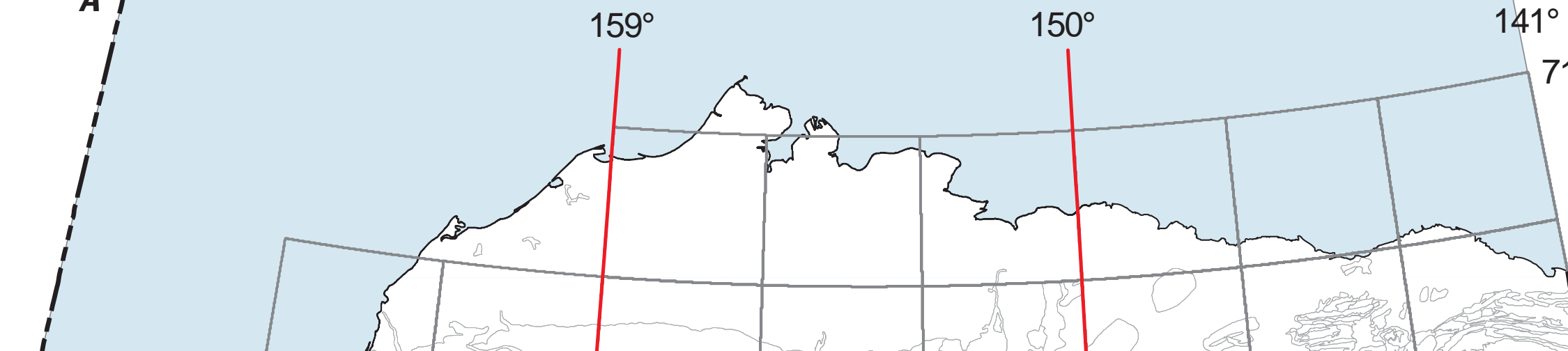

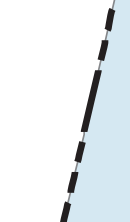
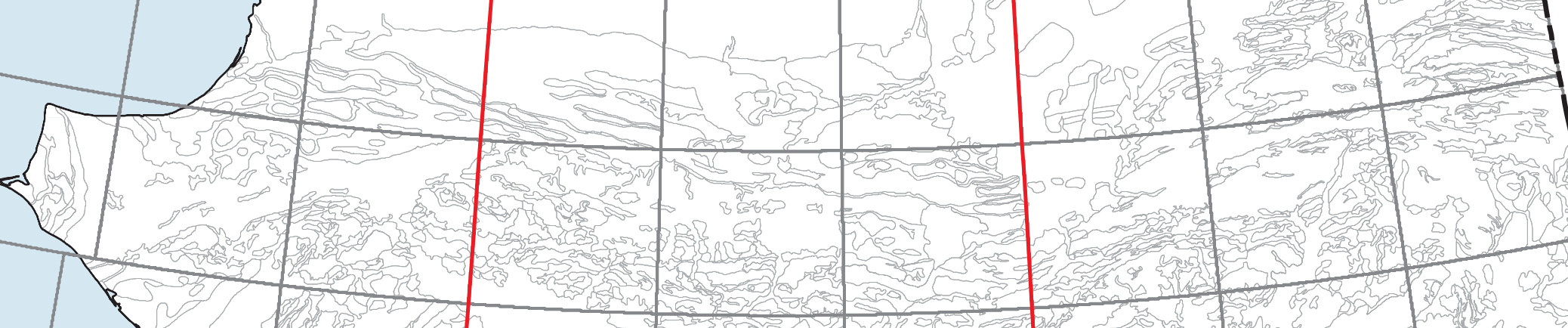

(-
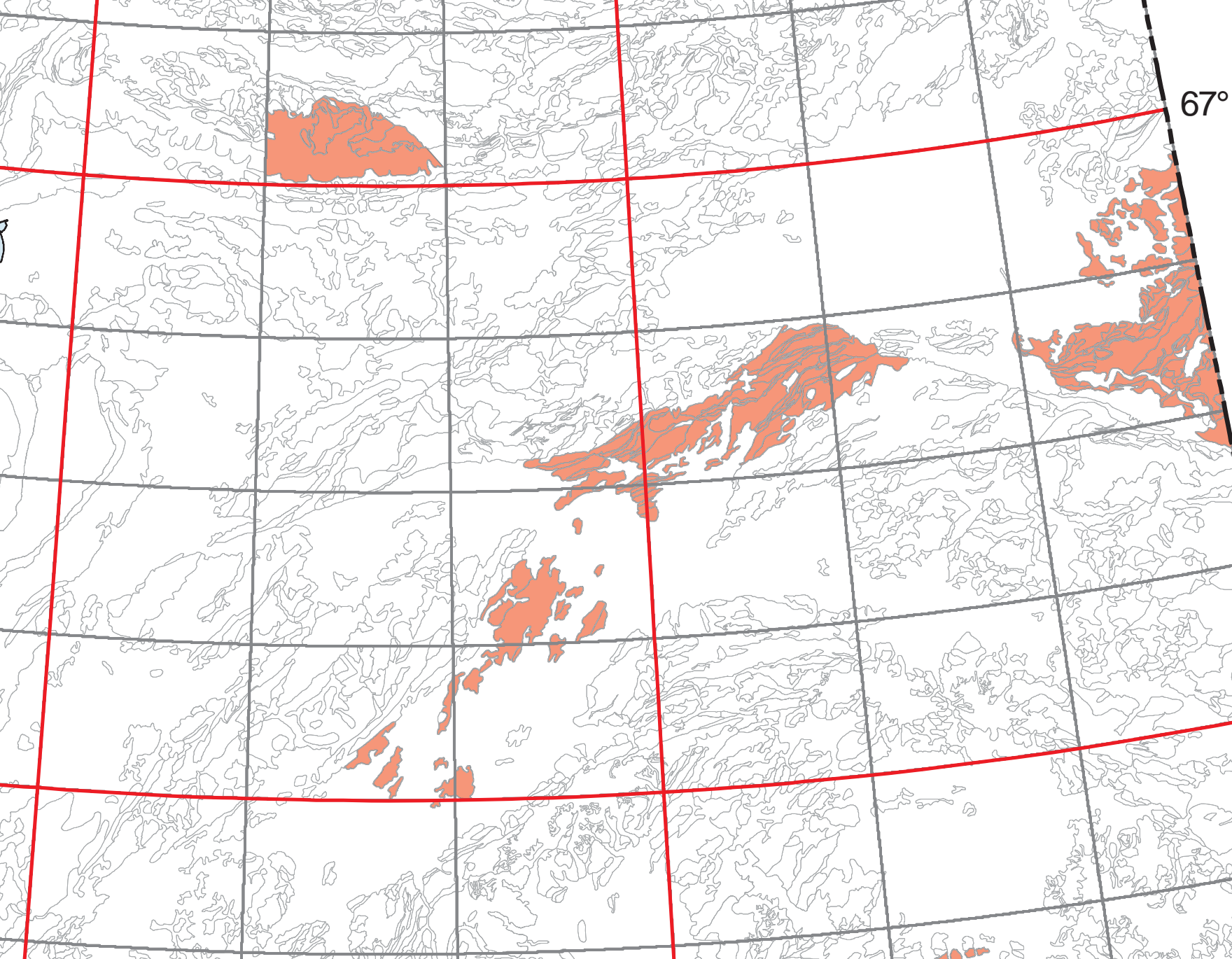


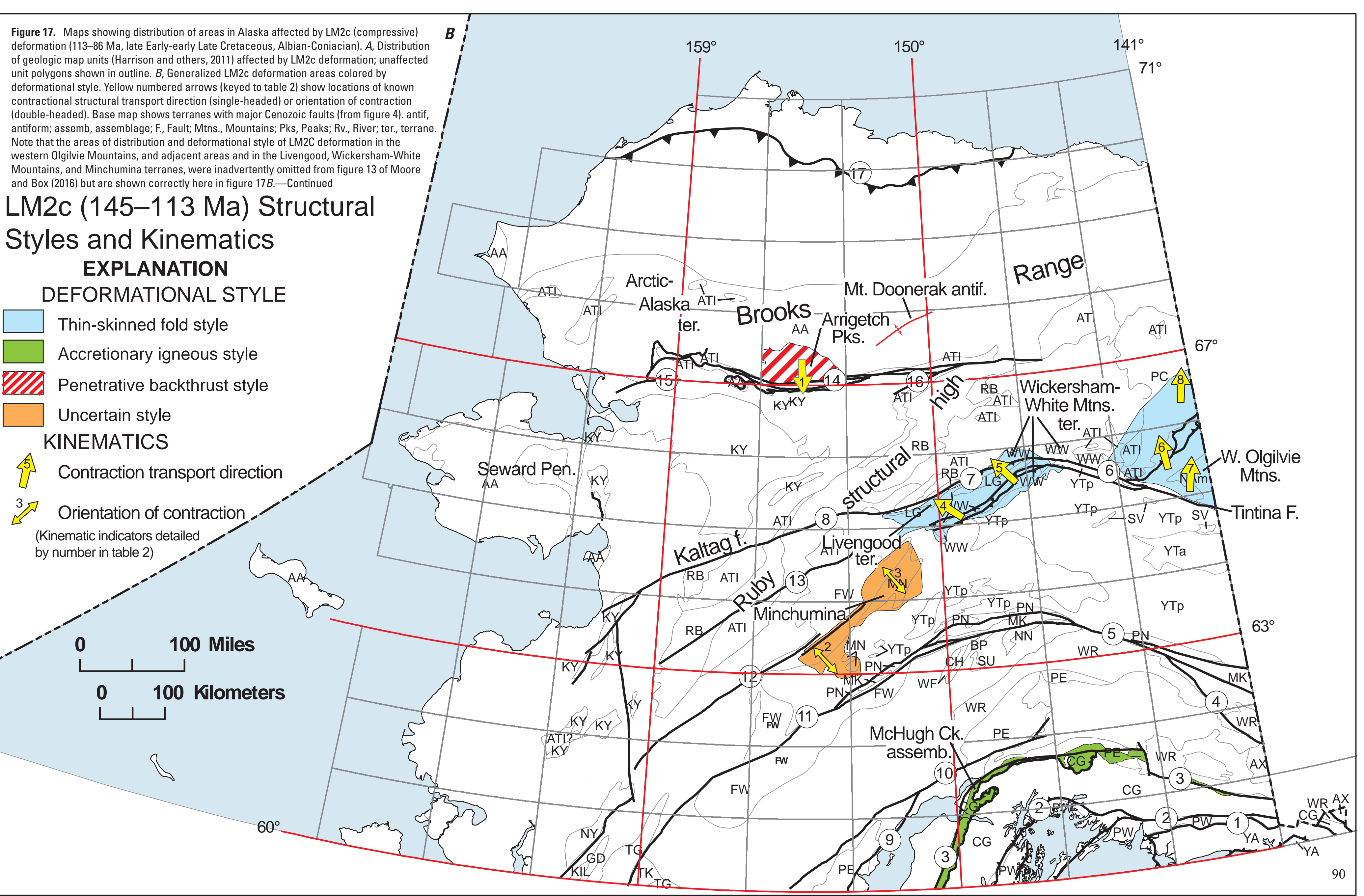




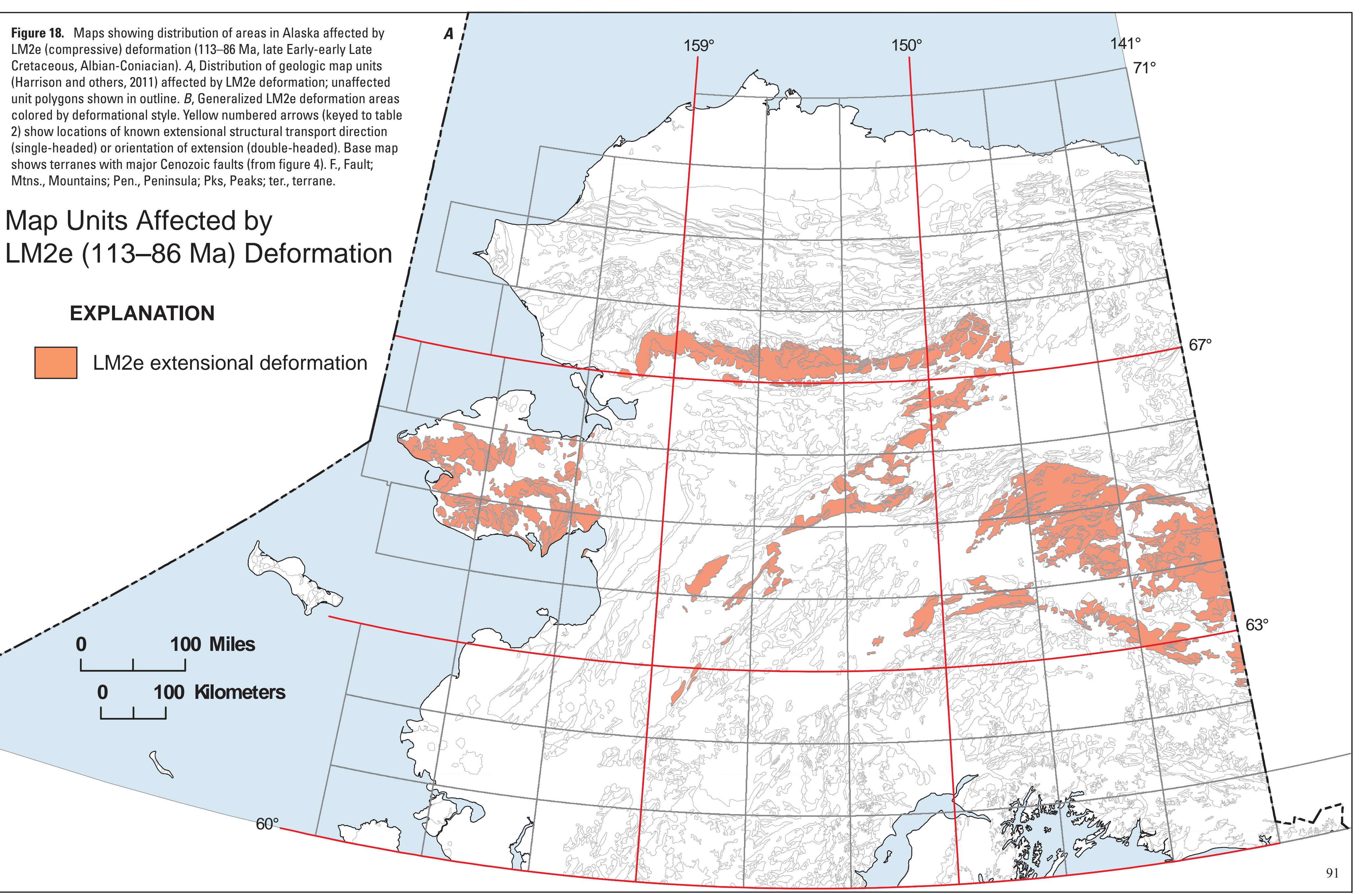




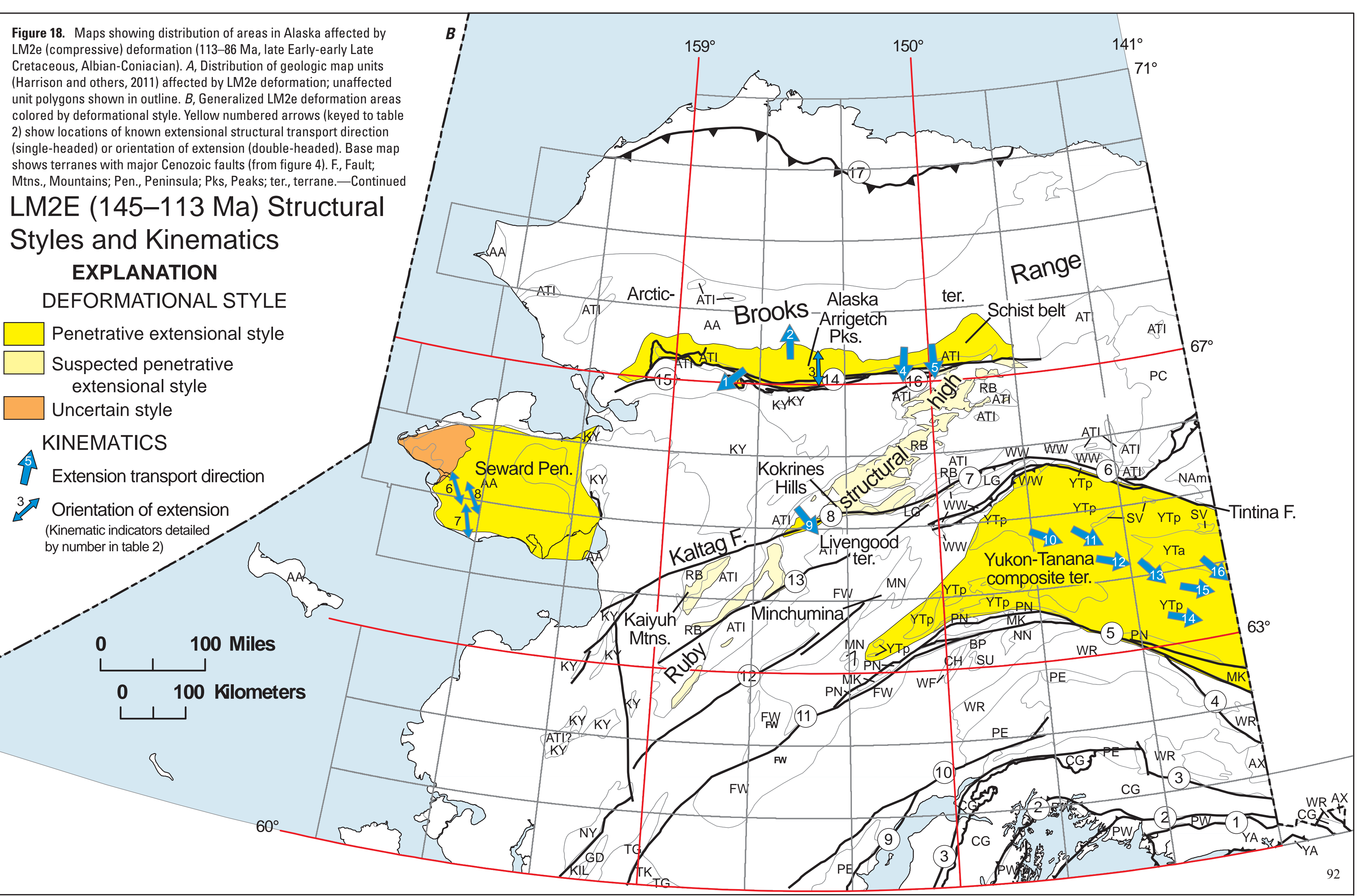




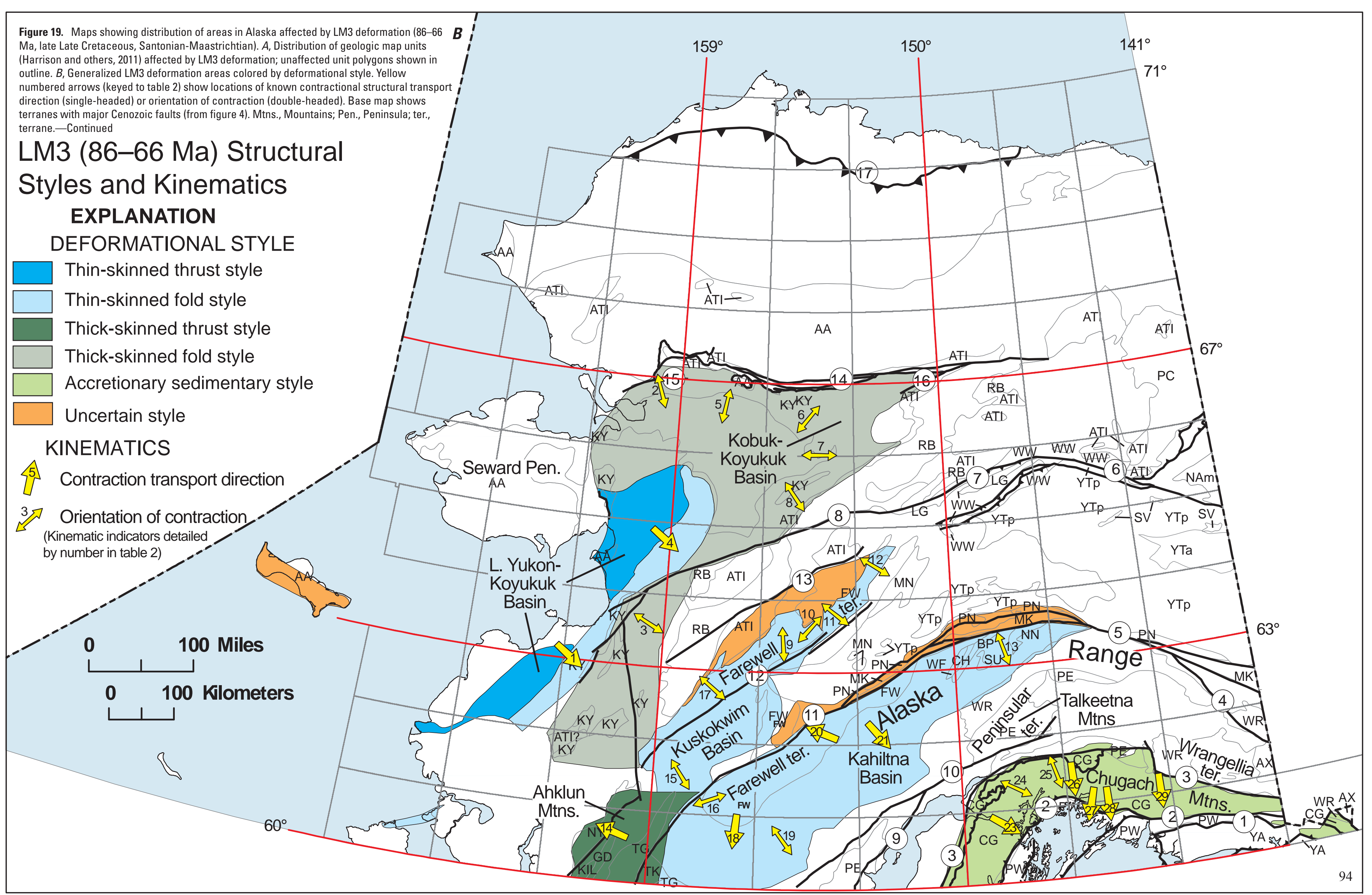




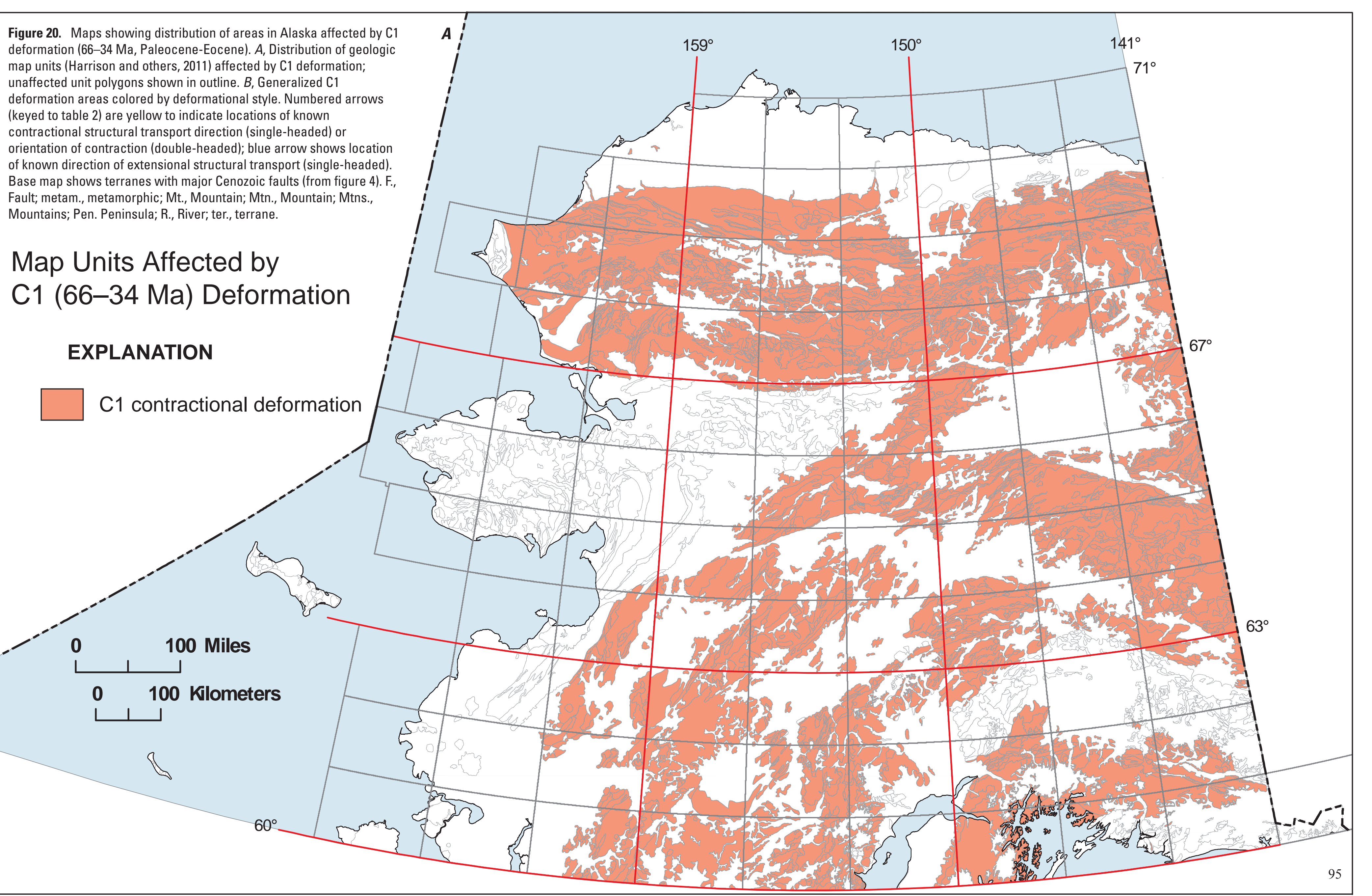




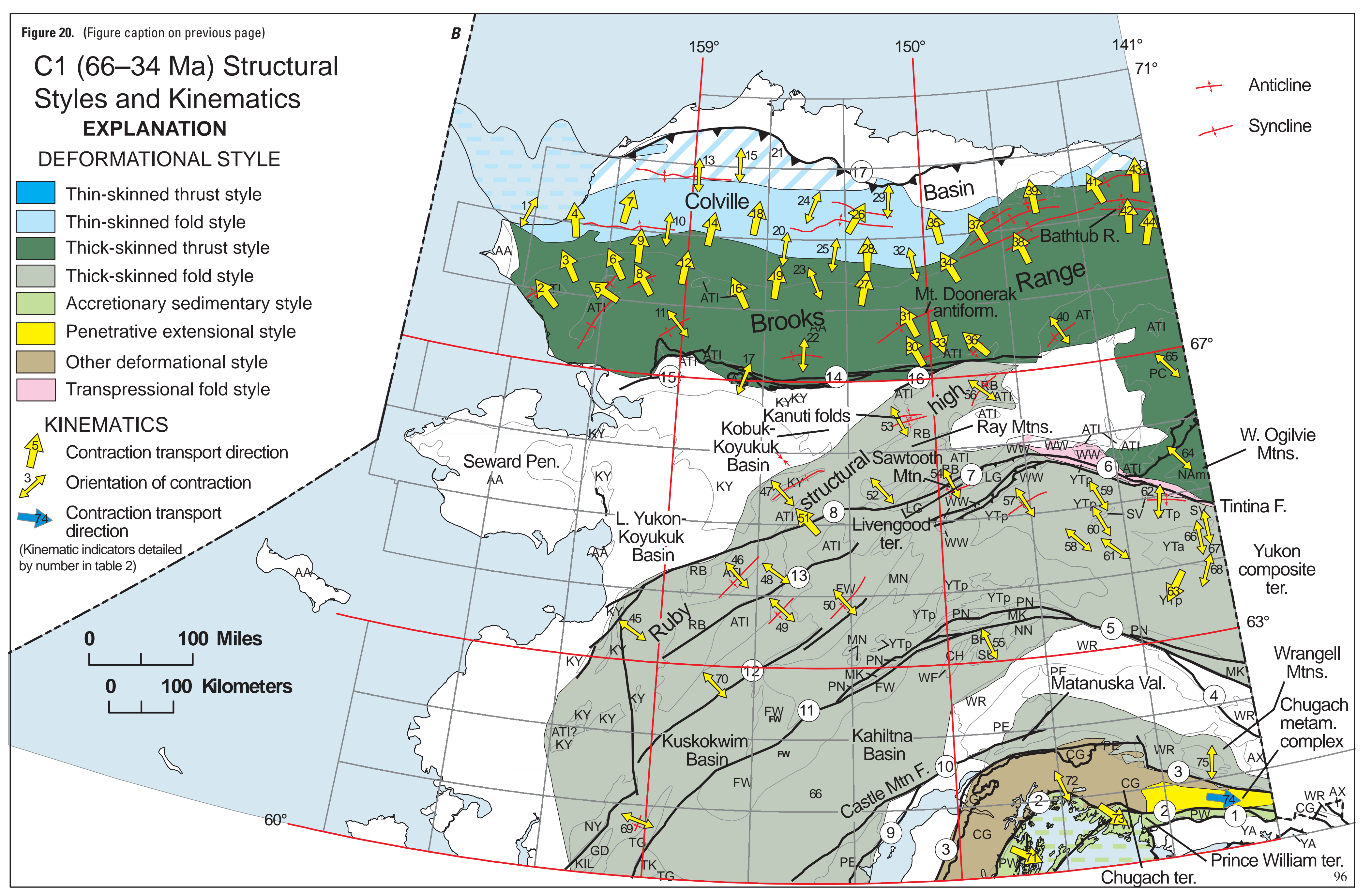


Figure 21. Maps showing distribution of areas in Alaska affected by C2 deformation (34-15 Ma Oligocene-early Miocene). $A$, Distribution of geologic map units (Harrison and others, 2011) affected by C2

deformation; unaffected unit polygons shown in outline. $B$, Generalized

C2 deformation areas colored by deformational style; diagonal pattern

indicates distribution of deformation in subsurface from onshore seismic

data; dashed pattern for offshore area from seismic data. Yellow

numbered arrows (keyed to table 2) show locations of known

contractional structural transport direction (single-headed) or

orientation of contraction (double-headed). Base map shows terranes

with major Cenozoic faults (from figure 4). antif., antiform; Ck., Creek.

\section{Map Units Affected by}

C2 (34-15 Ma) Deformation

\section{EXPLANATION}

C2 contractional deformation

\section{$0 \quad 100$ Miles}

0

100 Klometers

L
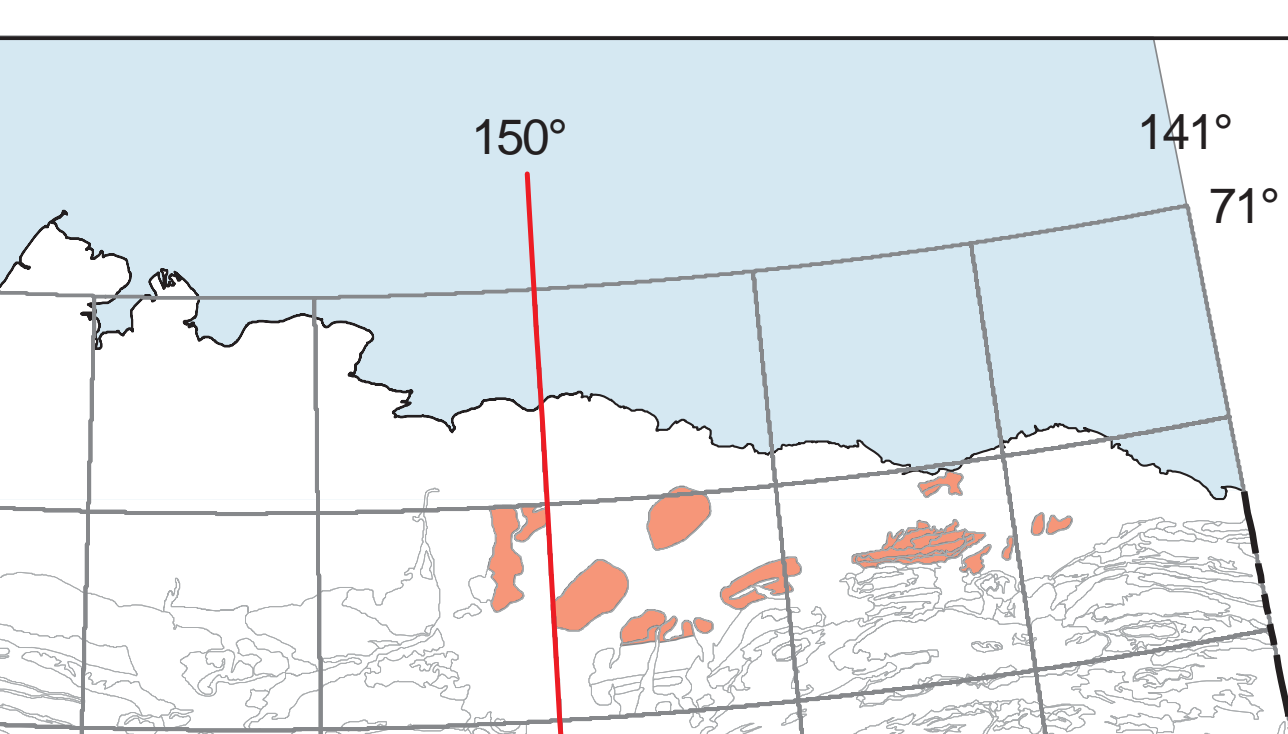


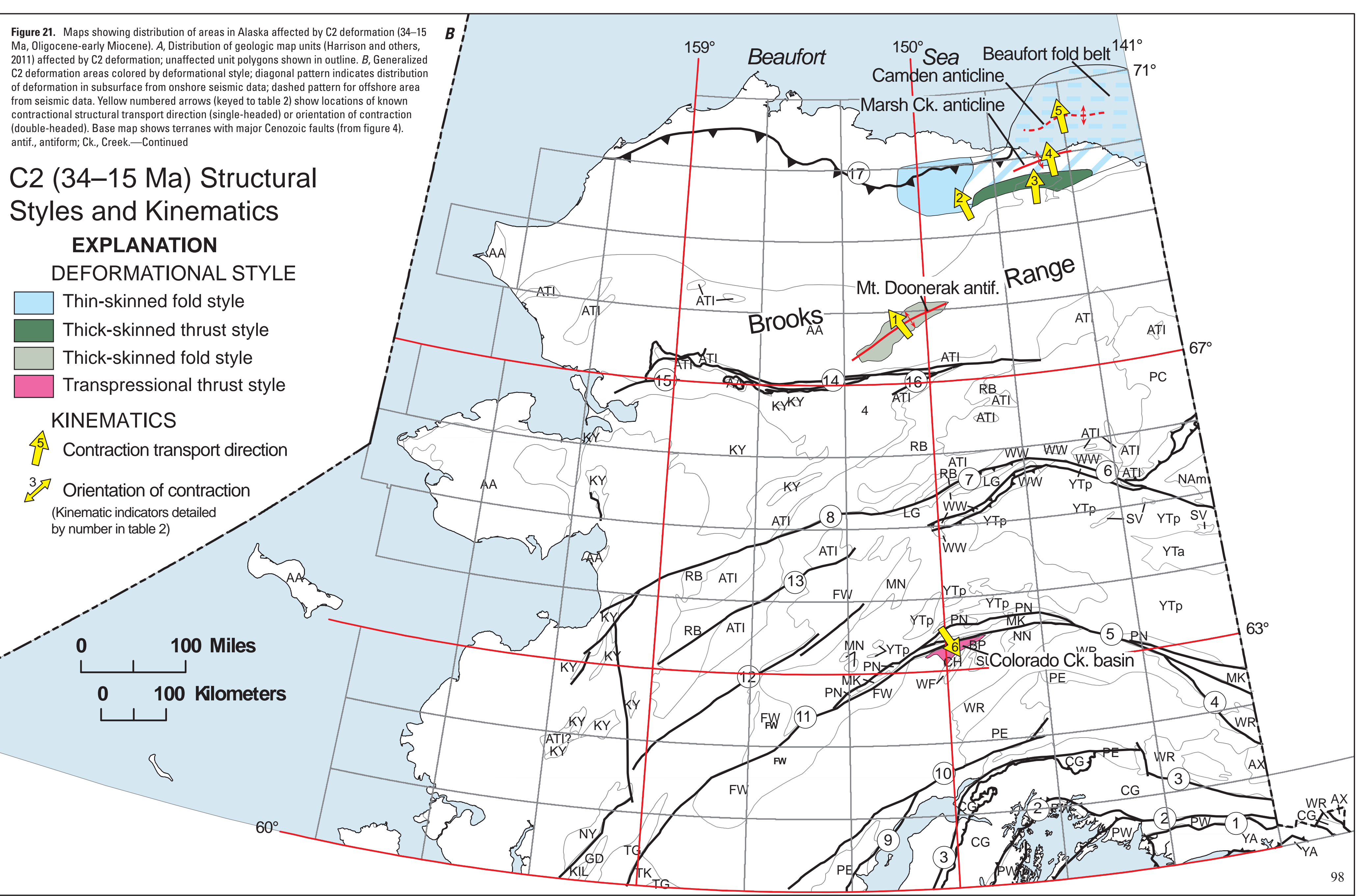


Figure 22. Maps showing distribution of areas in Alaska affected by C3 eformation (15-0 Ma, middle Miocene-Recent). A, Distribution of geologic map units (Harrison and others, 2011) affected by C3

deformation; unaffected unit polygons shown in outline. $B$, Generalized

C3 deformation areas colored by deformational style; diagonal pattern

indicates distribution of deformation in subsurface from onshore seismic

data; dashed pattern for offshore area from seismic data. Yellow

numbered arrows show locations of known contractional structura

transport direction (single-headed) or orientation of contraction

(double-headed). Base map shows terranes with major Cenozoic faults

(from figure 4). Ck., Creek; F., Fault; Mtns., Mountains; ter., terrane; Val.,

Valley.

\section{Map Units Affected by \\ C3 (15-0 Ma) Deformation}

\section{EXPLANATION}

C3 contractional deformation

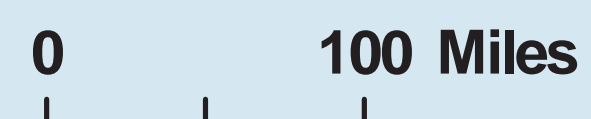

0

100 Kilometers

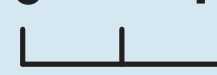

$60^{\circ}$

i
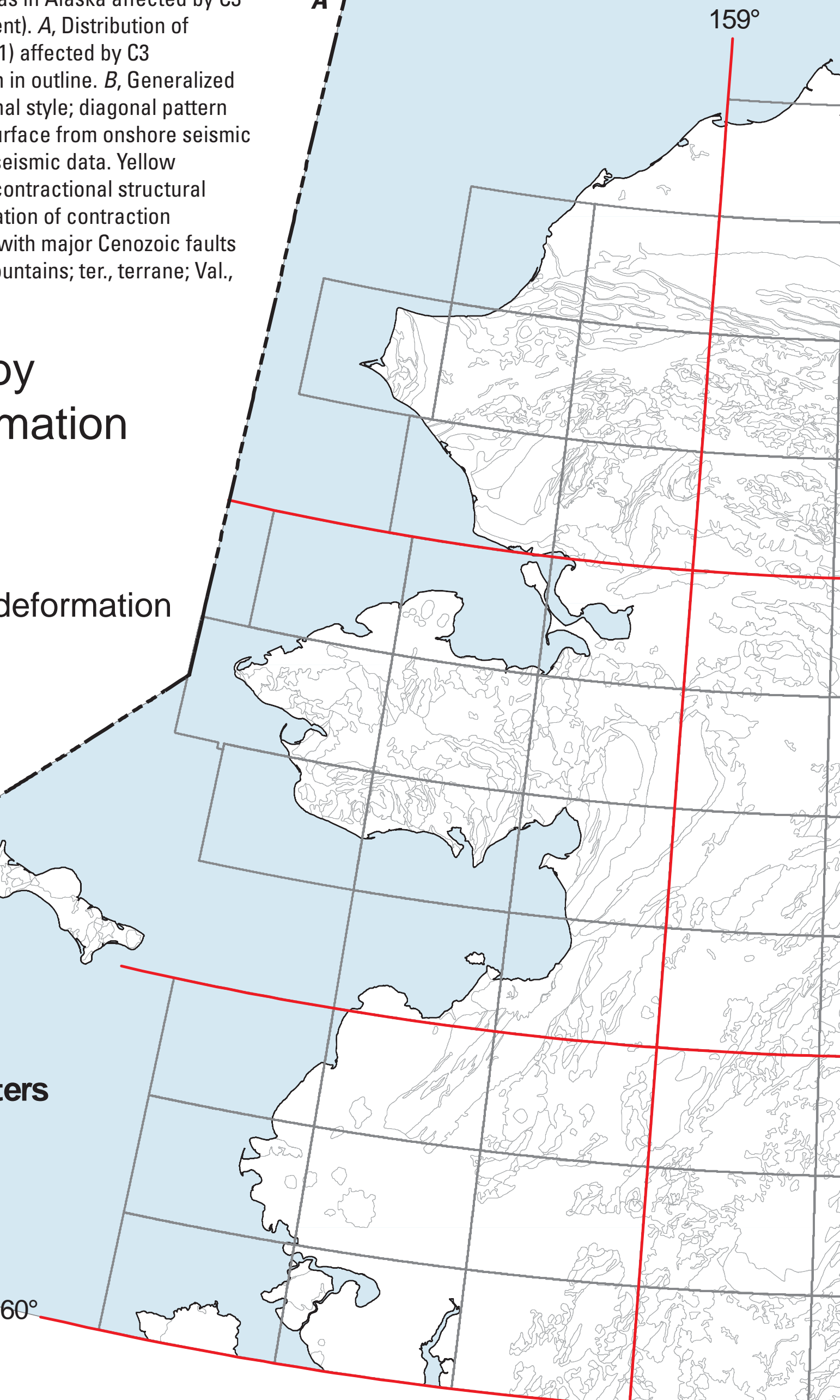
Figure 22. (Figure caption on previous page)

C3 (15-0 Ma) Structural Styles and Kinematics

\section{EXPLANATION}

\section{DEFORMATIONAL STYLE}

Thin-skinned thrust style

Thin-skinned fold style

Thick-skinned thrust style

Accretionary sedimentary style

Transpressional thrust style

Transpressional fold style

\section{KINEMATICS}

55 Contraction transport direction

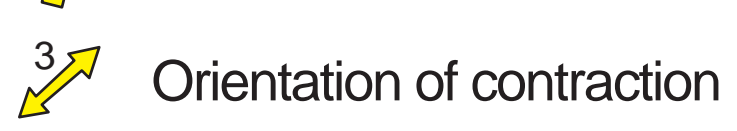

(Kinematic indicators detailed

by number in table 2)

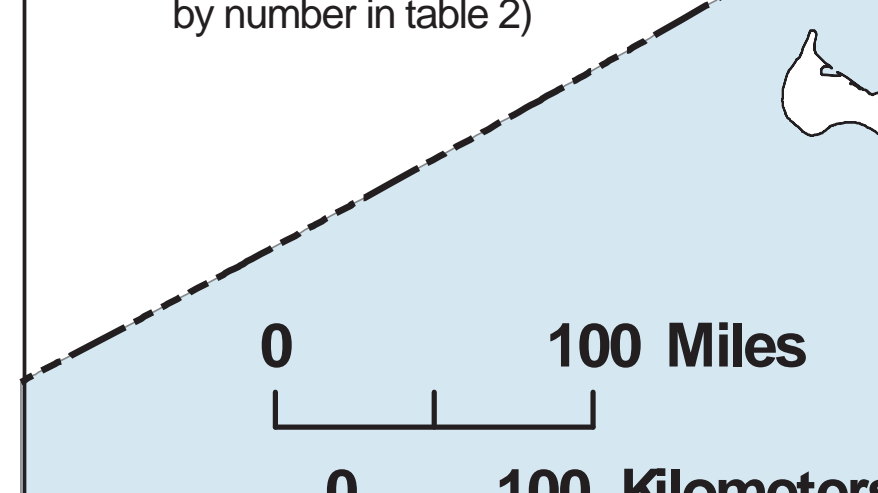

\section{$0 \quad 100$ Kilometers}

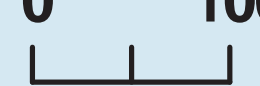

$60^{\circ}$
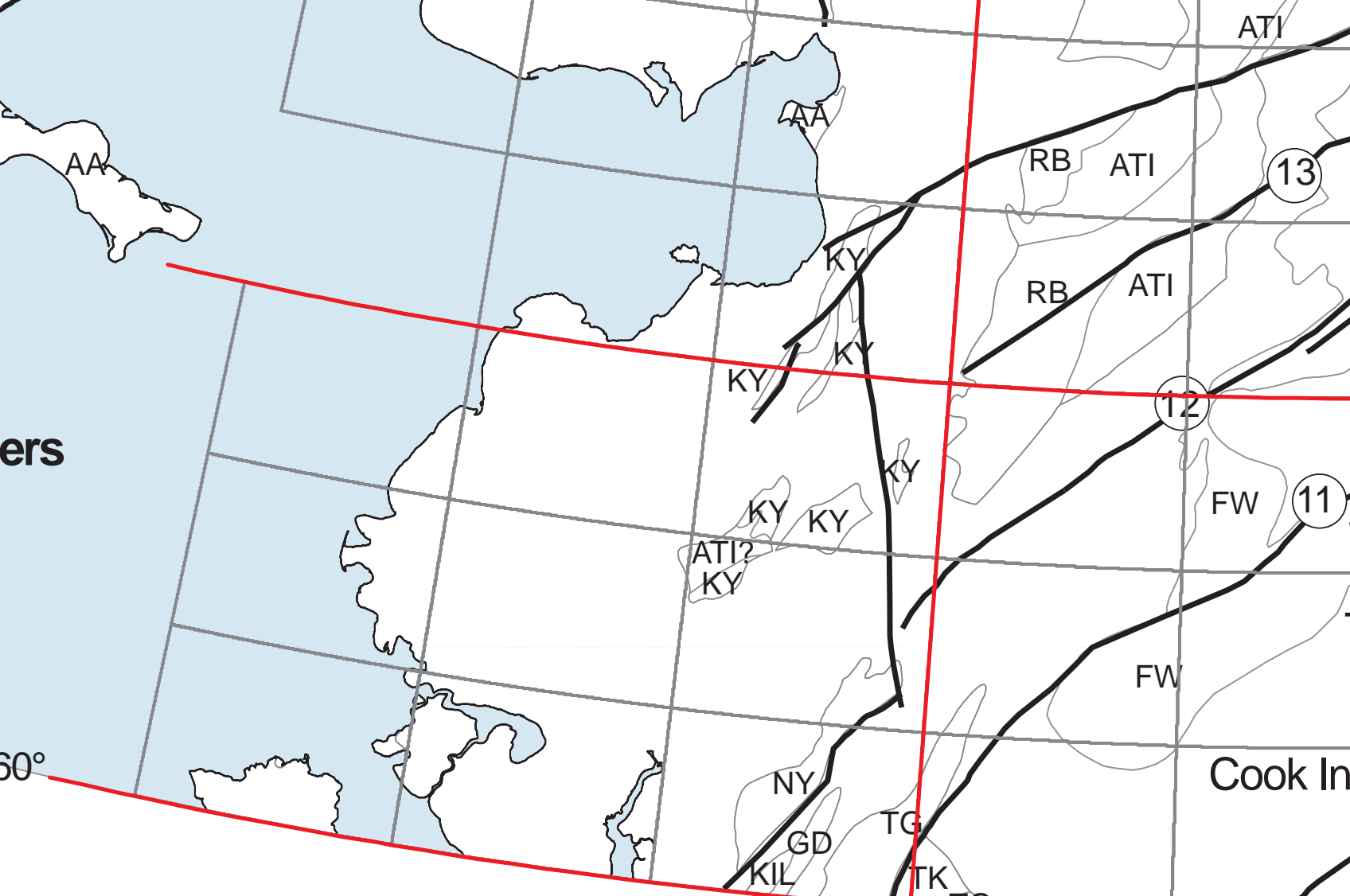

(11) alask

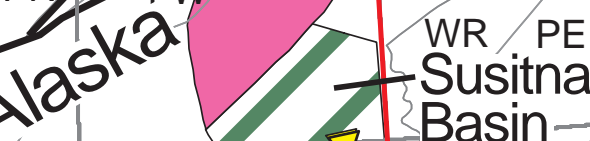




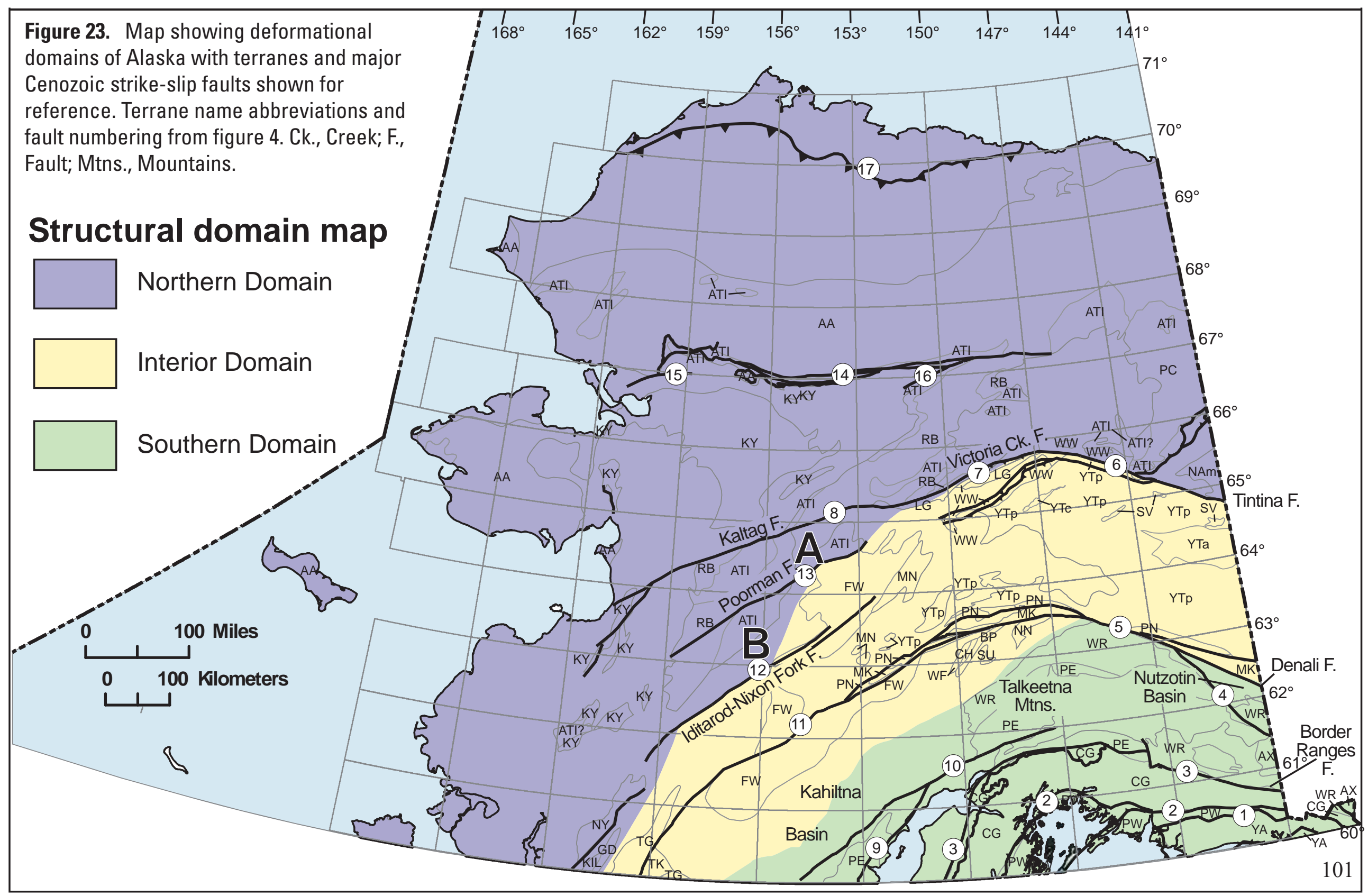

